\title{
Gubik Formation of
}

Quaternary Age in

Northern Alaska

EXPLORATION OF NAVAL PETROLEUM RESERVE NO. 4 AND ADJACENT AREAS, NORTHERN ALASKA, 1944-53

PART 2. REGIONAL STUDIES

GEOLOGICAL SURVEY PROFESSIONAL PAPER 302-C

Prepared and published at the request of and in cooperation with the U.S. Department of the Navy, Office of Naval Petroleum and Oil Shale Reserves

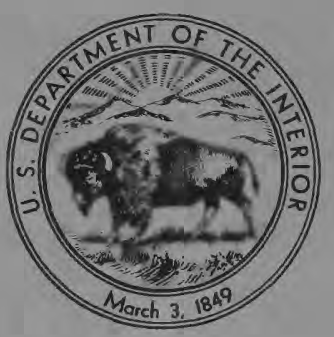




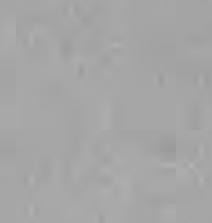

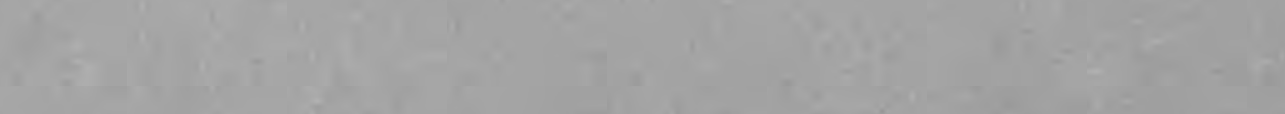

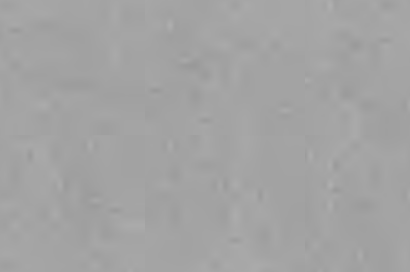

ict)

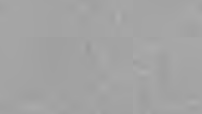

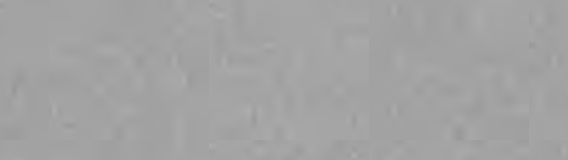

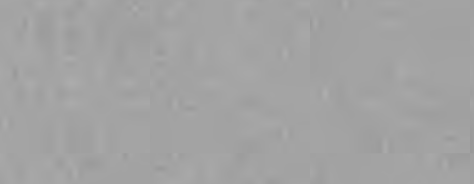

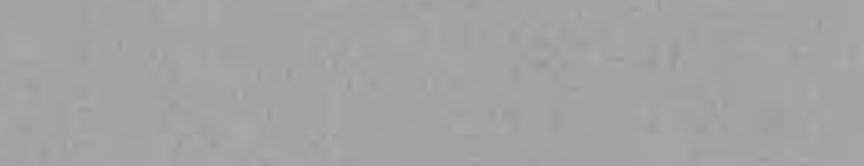

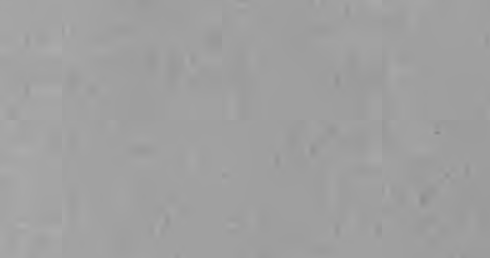

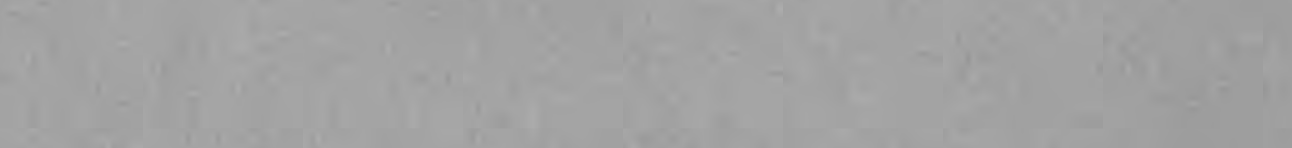

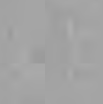

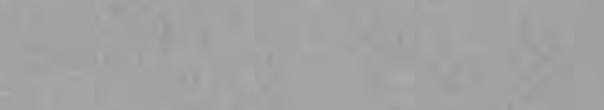
aris $i=$

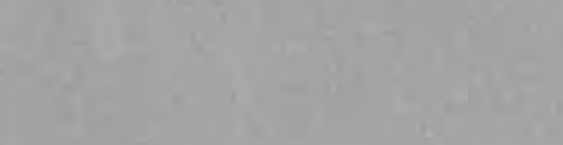

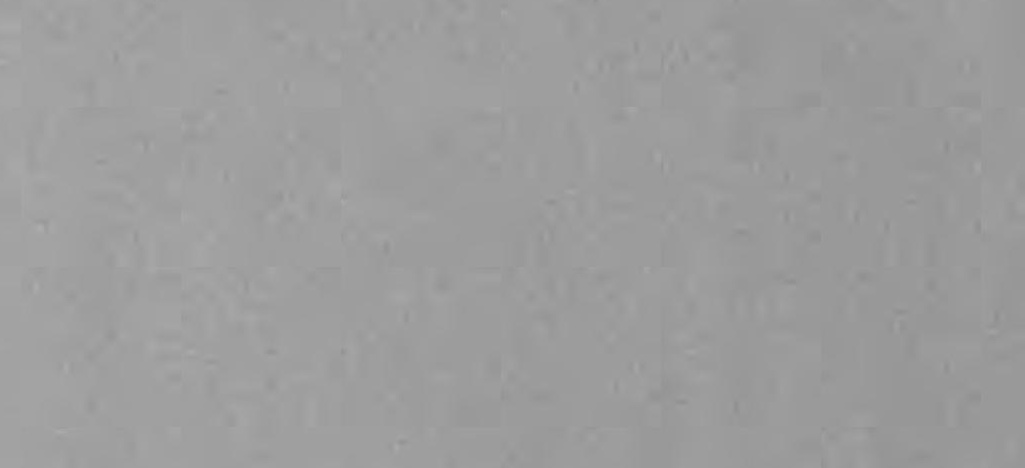

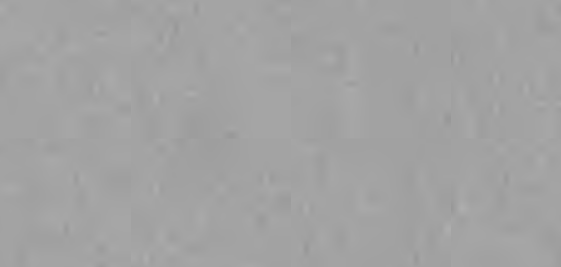

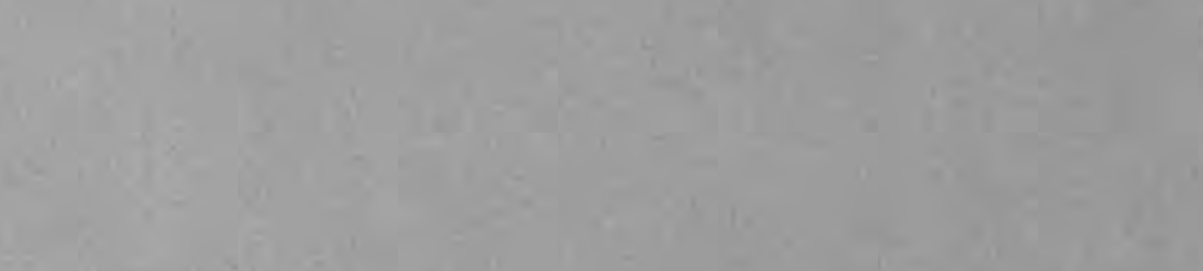

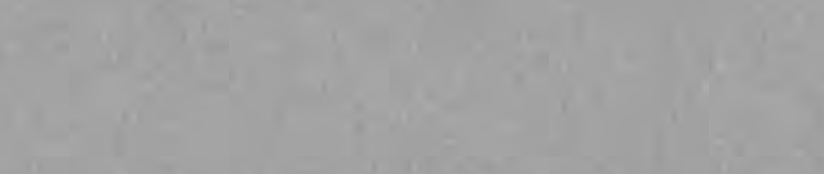

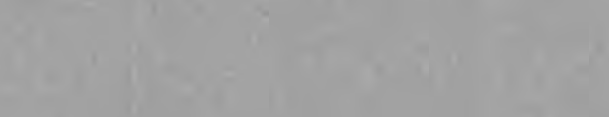

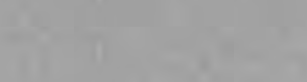
- $x^{2}=$

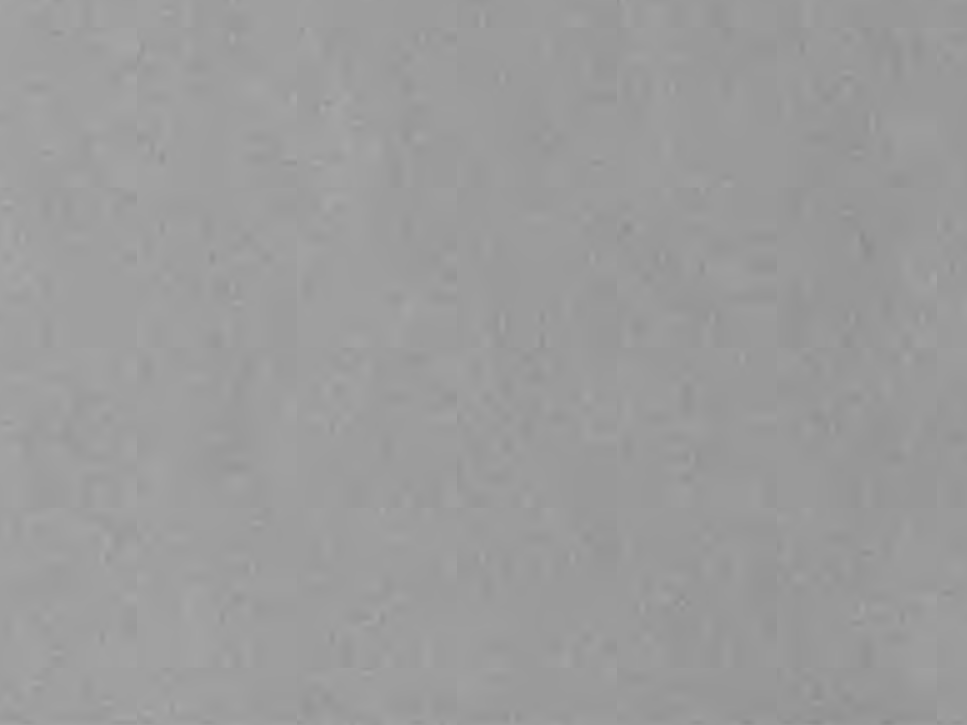




\section{Gubik Formation of}

Quaternary Age in

Northern Alaska

By ROBERT F. BLACK

EXPLORATION OF NAVAL PETROLEUM RESERVE NO. 4 AND ADJACENT AREAS, NORTHERN ALASKA, 1944-53

PART 2. REGIONAL STUDIES

GEOLOGICAL SURVEY PROFESSIONAL PAPER 302-C

Prepared and published at the request of and in cooperation with the U.S. Department of the Navy, Office of Naval Petroleum and Oil Shale Reserves

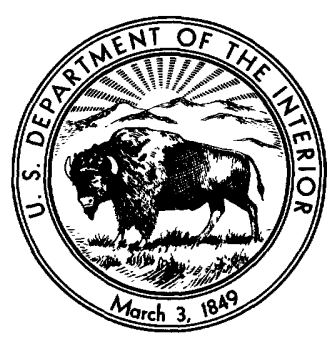

UNITED STATES GOVERNMENT PRINTING OFFICE, WASHINGTON : 1964 


\section{UNITED STATES DEPARTMENT OF THE INTERIOR \\ STEWART L. UDALL, Secretary \\ GEOLOGICAL SURVEY \\ Thomas B. Nolan, Director}

For sale by the Superintendent of Documents, U.S. Government Printing Office

Washington, D.C., 20402 


\section{CONTENTS}

\begin{abstract}
Introduction.

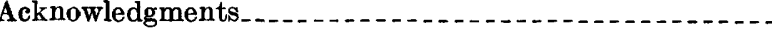

Geography and geology
\end{abstract}

Gubik Formation.

History

Mineralogy

Fossils_............

Subdivision of the Gubik Formation . . . . . .

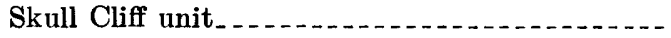

Locality descriptions.....................

Skull Cliff _. . . .

Drew Point......

Mitlitavik _...

Kokolik . . .

Nunavak . .

Christie Point

Meade River unit..........

Locality descriptions.

Sentinel Hill . . .

Topagoruk

Central Coastal Plain

Mitlitavik _.

Atigaru Point

\begin{tabular}{|c|c|c|}
\hline Page & & Page \\
\hline 59 & Gubik Formation-Continued & \\
\hline 59 & Subdivision of the Gubik Formation-Continued & \\
\hline 61 & Meade River unit—Continued & \\
\hline 61 & Locality descriptions-Continued & \\
\hline 62 & Ikpikpuk & 75 \\
\hline 62 & Admiralty Bay & 76 \\
\hline 63 & Ocean Point & 76 \\
\hline 63 & Meade River. & 76 \\
\hline 65 & Kikiakrorak & 76 \\
\hline 65 & Barrow unit.... & 77 \\
\hline 67 & Locality descriptions & 77 \\
\hline 67 & Skull Cliff $\ldots \ldots \ldots$ & 77 \\
\hline 68 & Walakpa & 78 \\
\hline 69 & Nunavak & 79 \\
\hline 69 & Christie Point & 79 \\
\hline 69 & Barrow & 80 \\
\hline 69 & Teshekpuk & 86 \\
\hline 70 & Peard Bay & 87 \\
\hline 73 & Cape Simpson & 87 \\
\hline 73 & Age and correlation of the Gubik Formation & 88 \\
\hline 73 & Geomorphic history of the Gubik Formation & 89 \\
\hline 74 & Engineering significance of the Gubik Formation.... & 90 \\
\hline 74 & References cited & 90 \\
\hline
\end{tabular}

\section{ILLUSTRATIONS}

FiguRE

9. Index map of northern Alaska

10. Distribution of Quaternary fossils

11. Sketch map of the Barrow area

12. Coastal bluff 1.5 miles northeast of Walakpa

13. Skull Cliff unit of the Gubik Formation showing ice

14. Size-grade cumulative curves of the Skull Cliff unit of the Gubik Formation from Drew Point area.....

15. Size-grade cumulative curves of the Skull Cliff unit of Gubik Formation from Kokolik River, Admiralty Bay, Walakpa, Christie Point, and Nunavak.

16. Ice in marine clay-silts of the Skull Cliff unit of the Gubik Formation below and lacustrine deposits with peat above .

17. Sand of Meade River unit of the Gubik Formation

18. Sandy clay-silt of the Meade River unit of the Gubik Formation

19-23. Size-grade cumulative curves of the Meade River unit of the Gubik Formation from:

19. Sentinel Hill....

20. Topagoruk River

21. Central part of the coastal plain and Ikpikpuk

22. Vicinity of Mitlitavik

23. Admiralty Bay and Atigaru Point.

24. Size-grade cumulative curves of the Barrow unit of the Gubik Formation from Walakpa.

25. Lacustrine deposits over fluvial(?) deposits

26. Part of the Barrow unit of the Gubik Formation at Nunavak

27-29. Size-grade cumulative curves of the Barrow unit of the Gubik Formation:

27. From Nunavak and Christie Point.

28. Barrow area, from airbase ice cellar.

29. Barrow area, from drill cores

30. Diagrammatic cross section through an uplifted bar

31. Size-grade cumulative curves of the Barrow unit of the Gubik Formation from Teshekpuk Lake.....

32. Size-grade cumulative curves of the Barrow unit of the Gubik Formation from Peard Bay 
$\cdot$

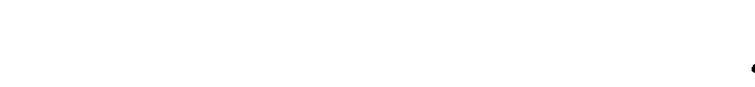




\title{
EXPLORATION OF NAVAL PETROLEUM RESERVE NO. 4 AND ADJACENT AREAS, NORTHERN ALASKA, 1944-53
}

\section{GUBIK FORMATION OF QUATERNARY AGE IN NORTHERN ALASKA}

\author{
By Robert F. Black
}

\begin{abstract}
The unconsolidated Gubik Formation of Quaternary age unconformably mantles rocks of Cretaceous or Tertiary age throughout the Arctic coastal plain province of northern Alaska. Data from many geologists of the U.S. Geological Survey, working in Naval Petroleum Reserve No. 4, are summarized, and the Gubik Formation in the coastal plain west of the Colville River is described. There, the Gubik consists largely of lenses and admixtures of silt and fine-grained sand in which quartz and chert predominate. Clay and gravel are lesser constituents. Accessory minerals are estimated to total less than 10 percent. The sediments are dominantly marine and are characterized by calcareous shallow-water invertebrate faunules much like those living along the coast today. Terrestrial vertebrate remains are sparse but widespread. Fluvial, lacustrine, eolian, and frost processes are also involved in the deposition or modification of the Gubik sediments.
\end{abstract}

The three main lithologic units are distinguished as follows: Skull Cliff unit-oldest; commonly consists of poorly sorted clay- to cobble-size sediment; commonly sticky or greasy; blue black to dark gray; mostly marine, but part may be glacially derived; deposited unconformably on Cretaceous rocks west of the Colville River; observed maximum thickness is 20 feet; poorly exposed.

Meade River unit-intermediate; consists of clean light-colored well-sorted quartz sand; mostly marine, but locally lacustrine and eolian; generally unconformable on Skull Cliff unit, but locally unconformable on Cretaceous bedrock and conglomeratic at base; especially loesslike in the southern and southeastern parts of the coastal plain; maximum thickness approaches 200 feet.

Barrow unit-generally youngest but in part contemporaneous with Meade River unit; consists of poorly sorted to wellsorted mixtures of clay, silt, sand, and gravel; color grades from light to dark; generally marine at base, but lacustrine and fluvial deposits characterize uppermost sediments; part may be glacially derived; ice locally constitutes more than half the volume; organic matter abundant in upper part; rarely deposited unconformably on the Cretaceous rocks; generally interfingers with the Meade River unit; a few tens of feet thick.

The Gubik represents a shallow near-shore shelf environment, in which frequent shifting of the strandline has occurred. Fossils collected do not pinpoint the age of any part of the Gubik but suggest that it may represent all the Pleistocene and part of the Pliocene. The sequence of deposition of the three lithologic units, as interpreted by the writer, agrees with the paleontologic sequence, but on the basis of the geomorphic evidence, the deposition of the three units did not require all the Pleistocene and late Pliocene. Only part of the Pleistocene is needed, but available data are insufficient to negate the paleontologic correlation. The geomorphic evidence consists of modification of geomorphic features, carbon-14 dates, archeologic findings, and growth rate of ice wedges. The Barrow unit, according to carbon-14 dates, must represent much, if not all, of the Wisconsin Glaciation. The Meade River unit then might be correlated with the Sangamon Interglaciation, and the Skull Cliff unit with the Illinoian Glaciation.

The geomorphic history of the Gubik is exceedingly complicated in detail and cannot be reconstructed now except in gross outline. The Arctic coastal plain is not a single plain but a number of surfaces of erosion and deposition in which uplift has not been uniform in either time or place. Warping of shore lines as high as 600 feet in elevation is recognized. Moreover, subaerial processes now affecting the Gubik seemingly did not all act with present intensity, if indeed they acted at all, during the brief emergences of the coastal plain during deposition of the Gubik. Conditions favorable for growth of ice wedges cannot be traced back much beyond 10,000 years without a break. Cold climates and the presence of permafrost, however, are recognized during the deposition of the upper 20 feet at least of the Barrow unit-a time apparently encompassing several tens of thousands of years. Apparently, too, the Skull Cliff unit, which is in part composed of glacial detritus, was laid down under similar conditions. In contrast, the Meade River unit was well winnowed by marine waters and modified extensively by wind action. No evidence of synchronous glaciation or cold climates has been recognized.

The Gubik Formation does not in itself produce unusual problems in engineering, but the fact that the material is perennially frozen and generally contains more ice than pore space is of great engineering significance.

\section{INTRODUCTION}

The unconsolidated Gubik Formation of Quaternary age unconformably mantles consolidated rocks of Cretaceous and of Tertiary age throughout the Arctic coastal plain province of northern Alaska (fig. 9), and widespread deposits of equivalent age are reported in northwestern Canada (MacKay, 1959; MacNeil, 1957). Although economic incentive for study of the Gubik Formation has been lacking, many geologists of the U.S. Geological Survey, working on projects in and adjacent to Naval Petroleum Reserve No. 4 during 1944-53, have 

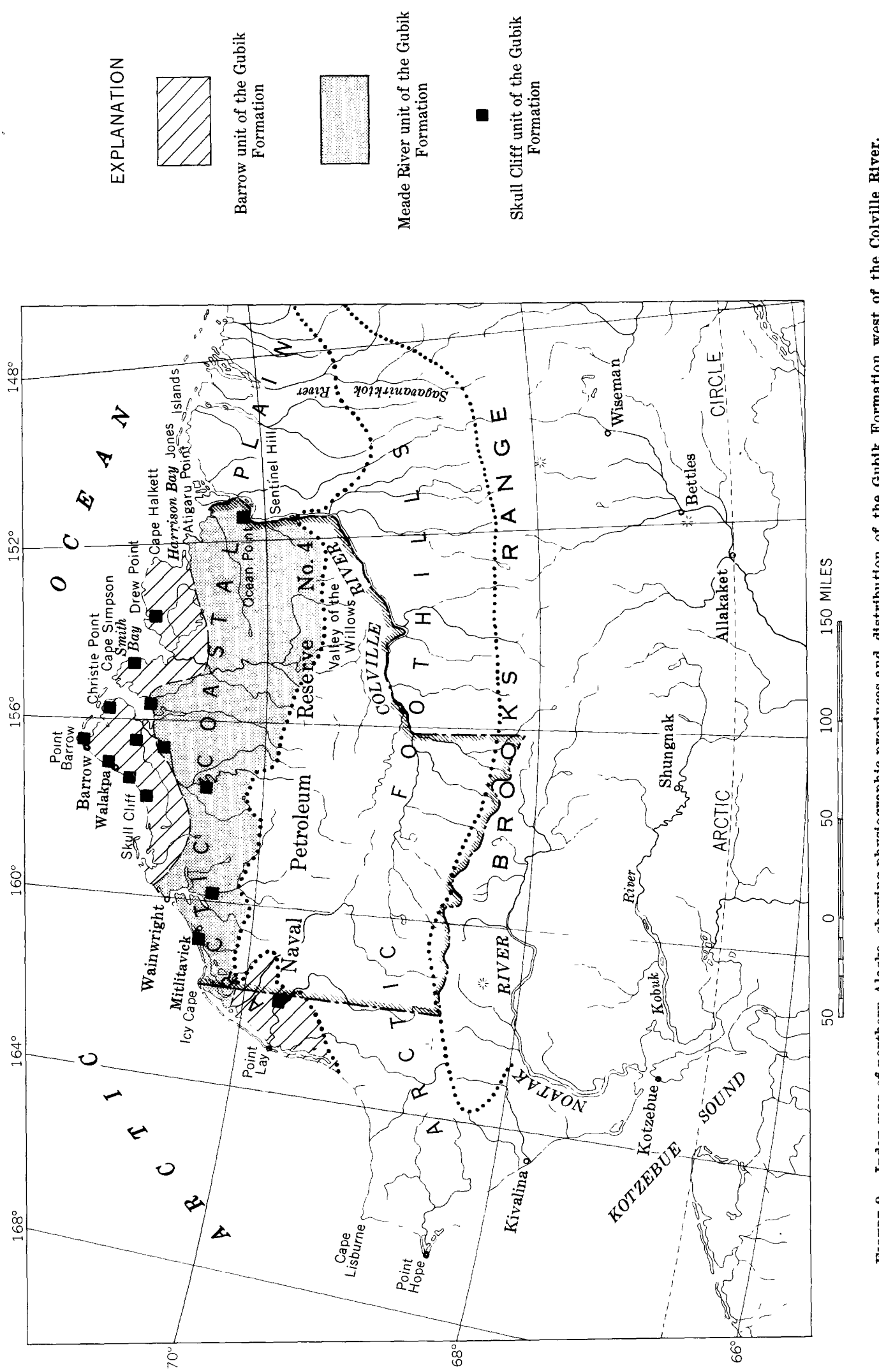
amassed much data on the nature and distribution of the Gubik Formation. These data have largely gone unrecorded or unassimilated in the published literature on northern Alaska. During the writer's studies of permafrost and geomorphology in northern Alaska, 1945-50, numerous brief observations were made of the Gubik Formation west of the Colville River, and the formation was subdivided into three lithologic units. In 1953 the writer compiled a summary of the observations made by him and by other personnel of the Geological Survey. In 1959 the writer used this summary to prepare the present paper without recourse to further field or laboratory work. This paper thus summarizes the available knowledge of the Gubik Formation west of the Colville River as of about 1950, although some of the more recent literature is cited.

Observation and sampling by the writer were made as time permitted, and detailed field studies of the Gubik Formation were not attempted. The writer collected 255 samples from various places in the coastal plain west of the Colville River, of which 147 have been analyzed mechanically. The grade scale of the National Research Council (1947) was used for textural classification. Each sample was examined under a binocular microscope. Some samples were checked with index oils and a petrographic microscope; however, no separations were attempted of light and heavy minerals, nor were detailed studies of mineralogy or paleontology made.

Planimetric maps at $1: 48,000$ scale provided the base for location of samples. Maps at $1: 250,000$ scale containing contours of $20-, 50-$, or 100 -foot intervals were available after the field studies were completed. Vertical aerial photographs of $1: 20,000$ scale reproduce all the coastal plain. Access to these maps and photographs, however, was very limited during the field study, and they have not been examined subsequently except in local areas. Consequently, known details of the Gubik Formation are limited to local areas or sections, and only broad generalizations subject to revision, are now attempted.

\section{ACKNOWLEDGMENTS}

The writer is indebted particularly to those U.S. Geological Survey personnel, referred to later in the text, from whom data on the Gubik Formation were obtained. The writer's knowledge of the Gubik was gained while making permafrost studies for the U.S. Geological Survey which, during 1949-50, were conducted in cooperation with the Office of Naval Research. During the summers of 1946 and 1947, limited observations were made at widely scattered points on the coastal plain west of the Colville River, utilizing float planes provided by the U.S. Navy and the U.S. Coast and Geodetic Survey. The coast for 100 miles southeast of Barrow and 40 miles southwest of Barrow was examined from small boats or on foot. Travel in the immediate vicinity of the naval airbase, 4 miles northeast of Barrow village and 6 miles southwest of Point Barrow, was accomplished mostly on foot, but weasels (amphibious tracked personnel carriers, M $29 \mathrm{C}$ ) were used during 1949-50 at the courtesy of the Arctic Research Laboratory.

Some logs of well drillers of Arctic Contractors (Reed, 1958, p. 34) were used in this study. Where used directly, such data are credited to the source. Mechanical analyses of samples were made by the writer, the U.S. Department of Agriculture, the St. Paul District Engineers Permafrost Research Laboratory, and the Rock Island Corps of Engineers, U.S. Army.

\section{GEOGRAPHY AND GEOLOGY}

Although the Gubik Formation occurs throughout the Arctic coastal plain province, the northernmost physiographic province in Alaska, only the part of the formation west of the Colville River was studied by the author. This area (fig. 9) includes most of the Teshekpuk Lake section (Payne and others, 1951). The White Hills section of the Arctic coastal plain, lying entirely east of the Colville River, is not included in the study area.

The Arctic coastal plain and the Arctic foothills (formerly the Anaktuvuk Plateau of Schrader, 1904, and the Arctic Plateaus of Smith and Mertie, 1930). constitute the Arctic Slope of Brooks (1906). The Arctic coastal plain is a flat, generally featureless plain, roughly triangular in shape, that extends from Cape Beaufort on the west to the International Boundary on the east. It reaches its maximum width of about 100 miles due south of Barrow. The plain is characterized by thousands of oriented and unoriented lakes and drained lake basins (Black and Barksdale, 1949), by meandering streams, by lack of marked relief, by numerous drained and undrained lagoons, by offshore bars, by numerous dunes and other eolian deposits (Black, 1951), and by omnipresent ice-wedge polygons (Black, 1952a and 1954) and other frost phenomena.

In that part of the province west of the Colville River, a slight angular unconformity separates the thin undeformed mantle of the Gubik Formation (Payne and others, 1951) from Cretaceous marine shale and some marine sandstone, siltstone, and mudstone. East of the Colville River early Tertiary nonmarine poorly consolidate conglomerate, silty sandstone, and siltstone of the Sagavanirktok Formation overlie the Cretaceous rocks and underlie the Gubik Formation or exclude it. 
The Tertiary and Cretaceous rocks are exposed very rarely in low bluffs along the Arctic Ocean and along some major streams. These and older rocks to the south in the foothills and Brooks Range are the source of most of the Gubik Formation but otherwise have little direct bearing on the present study.

The Arctic coastal plain province is bounded on the north by the Arctic Ocean under which the profile extends with little or no break in slope. The province is bounded on the south by the Arctic foothills province, in places with distinct topographic break. To the west of the Colville River that boundary generally is between 200 and 600 feet above sea level; to the east of the Colville River it reaches a maximum elevation above sea level of about 1,200 feet on the Okpilak River (Leffingwell, 1919, p. 53). As pointed out by Brooks (1906, p. 46), the southern boundary is gradational in places and is arbitrarily chosen; there it is a zone as much as 20 miles wide. The main distinctions between the provinces are in topography and genesis. The coastal plain has little relief and is underlain by flat-lying unconsolidated sediments of Quaternary age, whereas the foothills are rolling uplands or plateaus with beveled consolidated rocks of Cretaceous age at the surface. The coastal plain was built by deposition whereas the foothills were formed by erosion.

In summarizing the tectonic elements of Alaska, Payne (1953) showed the Meade and Barrow arches separating the Chukchi basin on the west and the Umiat basin on the east. Thus, Cretaceous bedrock (Webber, 1947 , p. $9-10$ ) is nearer to the surface west of the Meade River than it is east of the river. Between the Meade and Kuk Rivers, the Avalik and Nigisaktuvik Rivers flow on or near bedrock, whereas east of the Meade River the Usuktuk and Topagoruk Rivers are separated from bedrock probably by a considerable thickness of Gubik sediments, except in their headwaters in the Arctic foothills.

\section{GUBIK FORMATION}

\section{HISTORY}

The early explorers in northern Alaska were far more interested in the geography of the area than in unconsolidated sediments or soils composing the surface of the coastal plain. Except for isolated comments regarding "ice," "mud," height of coastal bluffs, coal deposits, glacial erratics, and character of the low coastal banks, little was added to our knowledge of the geology of the area. The early explorations were reviewed by Leffingwell (1919, p. 69-92), and a summary of the knowledge amassed about the Gubik Formation was later given by Smith and Mertie (1930, p. 236-254).

Dall and Harris (1892, p. 260-268) were among the first to attempt geologic mapping of the surficial ma- terials. They described the "ground ice formation" and the "Kowak clays" (Kobuk). In northern Alaska, these materials consist of

solid beds of ice of considerable thickness [that] perform the functions of rock strata and are covered by beds of blue clay containing numerous remains of Pleistocene mammals. $* * *$ At a depth of 2 feet is a stratum of pure ice (not frozen soil), of unknown depth. This formation extends, with occasional gaps, [from a point somewhat north of Cape Beaufort] north to Point Barrow, and thence east to Return Reef, where the ice layer is about 6 feet above the level of the sea.

The ice was considered to be older than the Pleistocene mammoth and fossil horse found in the associated clays. The name of "Kowak clays" was suggested by Dall and Harris (1892, p. 265-266) for the clays independently deposited or superposed on the ground ice formation at the type locality on the Kowak (Kobuk) River. The clays were described as being associated with elephant remains at Skull Cliff and at many places between Barrow and the mouth of the Colville River. Although the clays were considered to be Pleistocene in age, neither they nor the fossil localities were described.

Schrader (1904, p. 91-93) considerably reduced previous estimates of the areal extent of the ground ice formation and the Kowak clays and introduced the term "Gubik sand" of Pleistocene age.

It not only forms the surficial terrane of the coastal plain along the Colville, but seems to occur at some localities along the coast from the mouth of the Colville westward, in some instances apparently overlying the ground ice and probably the Kowak clay formation, while its inland margin probably overlaps the coastal edge of the Upper Cretaceous of the Nanushuk series. $* * *$ The deposit consists of fine sand, with apparently an admixture of considerable silt. In some localities it seems to be more sandy toward the base, and more earthy toward the top. *** It is ordinarily free from gravel, but in several instances subangular cherty pebbles ranging from mere sand grains to fragments as large as one-fourth inch in diameter were found. These occur very scatteringly and are sometimes roughened, as if wind worn. $* * *$ The deposit as a rule is structureless or without stratification planes.

The deposit was called loess in the field for lack of a better term, but Schrader, recognizing that no one hypothesis of origin was satisfactory, considered it a produet of "fluviatile delta [deposition] in conjunction with shallow coastal conditions and intense arctic freezing."

Leffingwell (1919, p. 150) believed that the term Gubik was derived by the improper spelling of the Eskimo name for the Colville River-Kupik. Nonetheless, the term Gubik has been accepted in the literature and in recent years has been broadened in scope to encompass all unconsolidated surficial materials overlying the Cretaceous or Tertiary rocks in the coastal plain. This usage is retained. 


\section{MINERALOGY}

The Gubik Formation consists largely of complexly intercalated lenses and admixtures of silt and finegrained sand. In places, clay is especially abundant in the lower part of the formation, but elsewhere gravel is common near the base. Coarse-grained sand and gravel are thinly distributed throughout much of the vertical range of the deposits but are absent in many places. Near the surface, ice composes in places more than half the bulk of the sediments, and organic matter is also abundant. Locally, the formation reaches a thickness of about 200 feet; in most places however, it is only a few tens of feet thick. The sediments are dominantly marine, but fluvial, lacustrine, eolian, glacial, and frost processes are involved in the deposition of the Gubik sediments at many localities. Wide variation of types is characteristic of most sections, but some zones of sand apparently extend horizontally many tens of miles with little change in texture or mineralogy.

The Gubik Formation is characterized by a complex suite of minerals (Payne and others, 1951; Morris, 1952) derived, in large part, from the Cretaceous rocks underlying it and, in some part, from sources outside the province. No suites of minerals can now be given as being representative of facies or units of the Gubik. Generally, all minerals found in one unit also occur in the others. Statistical studies to determine percentages of minerals in the various units have yet to be made; not all minerals occurring in the formations have been identified.

Quartz is the dominant mineral, but in places chert is almost equally abundant. These minerals are obviously of several generations. Some of the grains probably date back to Paleozoic rocks in the Brooks Range, and have been worked and reworked several times by different agents of erosion and deposition; others are secondary in origin, such as doubly terminated euhedral crystals, and were formed in place. The quartz is clear and colorless or is colored yellow, pink, red, brown, and black. Surface stains of organic matter, carbonates, iron oxides, manganese, and other materials are common on some well-rounded grains. Other well-rounded grains are either smooth and polished, frosted or pitted, or angular and fresh. Inclusions within the quartz are abundant and of many kinds. Liquid and gas inclusions were seen; rutile and other unidentified inclusions are common. The chert is black, dark gray, brown, dark green, tan, buff, and cream. Most grains are well rounded, smooth, and polished; some are pitted, frosted, and stained; others are angular and fresh.
The other minerals also display a complete range from angular fresh unstained grains through well-rounded and polished or pitted grains to highly altered, weathered, or stained grains. The following minerals have been tentatively identified, although no intensive search or study has been attempted: garnet, andalusite, epidote, glaucophane, hornblende, zircon, chloritoid, biotite, muscovite, tourmaline, magnetite, ilmenite, andesine, orthoclase, microcline, kaolinite, illite, calcite, sphene, oligoclase, pyrite, rutile, pyroxene, olivine, hypersthene, volcanic glass(?), monazite, apatite, and staurolite. In many places the accessory minerals make up only 1 or 2 percent of the total, but locally it is estimated that they constitute 10 percent of the total.

Most gravel is composed of well-rounded polished chert, but some frosted, pitted grains are found locally. The darker-gray flinty varieties have typical percussion rings. Erratics compose a small percentage of the total (MacCarthy, 1958); a few of them are seemingly foreign to the bedrock of northern Alaska, including the Brooks Range. The foreign erratics include primarily red to gray granite and granite gneiss, dark hornblende diorite, and other igneous rocks. Some boulders measure several feet in diameter. Red, brown, yellow, and tan quartzite in cobbles several inches in diameter are as abundant as the igneous materials. These cobbles are generally well rounded and polished. Dark-gray to red fossiliferous marble resembling the Carboniferous marble of the Brooks Range is less common. In places, angular fragments of Cretaceous sandstone and coal derived locally are very abundant, especially near the lower part of the Gubik Formation.

Mineral determinations of the clay- and silt-size fractions of the Gubik Formation have not been attempted.

\section{FOSSILS}

Pleistocene to Recent fossils (Smith and Mertie, 1930, p. 251-254; Tappan, 1951; and MacNeil, 1957) (fig. 10) in the Gubik Formation include: marine invertebrate Foraminifera, ostracods, pelecypods, and gastropods; terrestrial vertebrate mammoth, mastodon, bison, horse, and musk ox; and fragments of deciduous and coniferous trees, shrubs, and vascular plants. Some localities are shown on figure 10. No systematic studies of the regional distribution and stratigraphic changes of the Gubik fossils have been attempted. Consequently, generalizations are limited to the environmental significance of local collections.

The marine fossils are invariably calcareous shallowwater forms, identical with or similar to those living in the sea today. No pelagic species are known. All are notably tolerant of brackish water. The vertebrate fossils have been found largely at or near the surface 


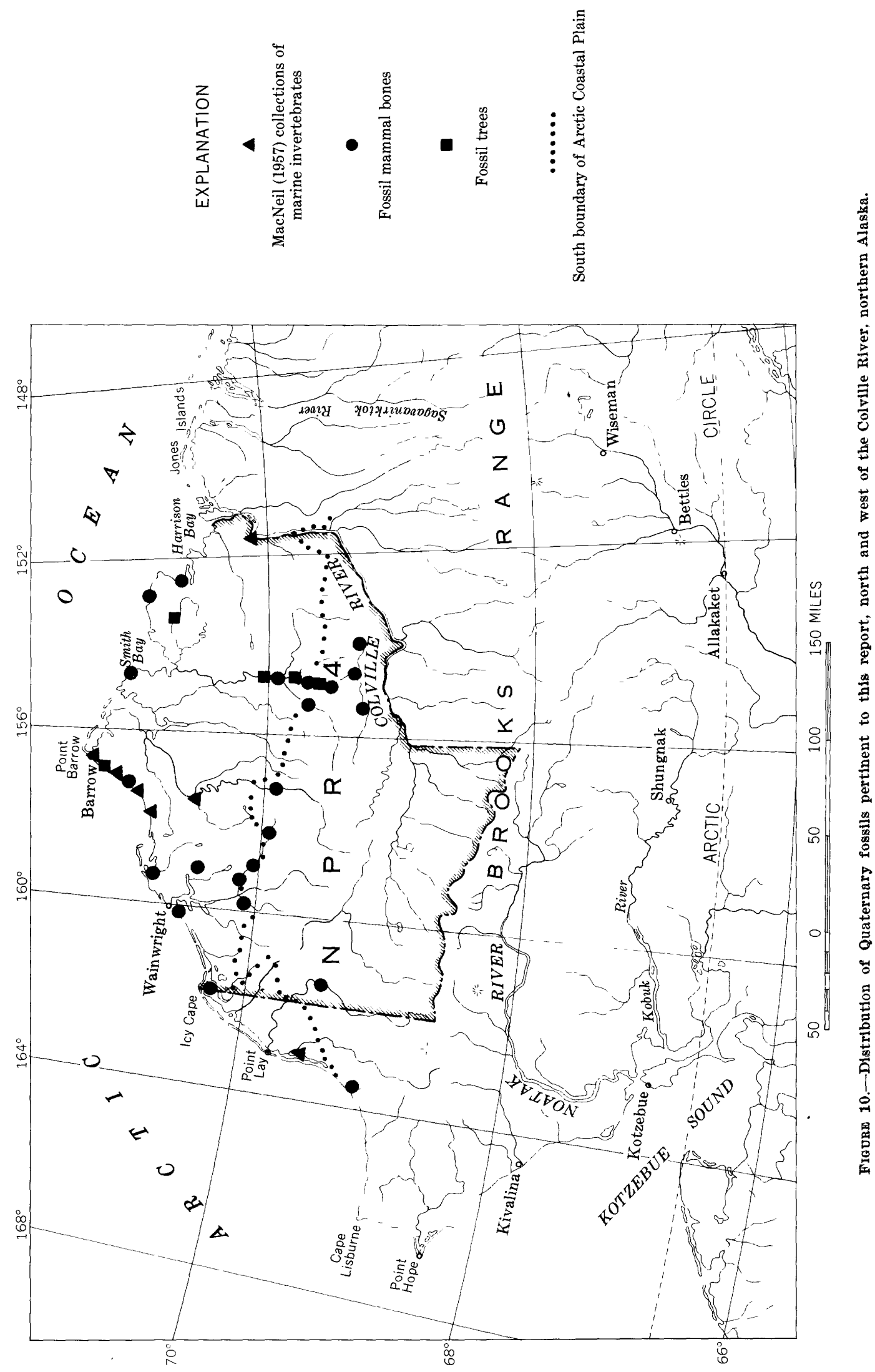


of the Gubik and in lacustrine or fluvial sediments. The musk ox is not now found in the coastal plain but has been reported in the area within historical times. The other vertebrates are Pleistocene in age but lived during a span of about a million years, from early Pleistocene to a time about 8,000 years ago (Sellards, 1952). To the writer's knowledge all vertebrate fossils have been transported at least short distances and are hence of only general stratigraphic significance.

The logs of deciduous and coniferous trees in the coastal plain are invariably erratic, having been floated by water to their present resting places. A possible source of the logs is the foothills, where similar $\operatorname{logs}$ rooted in place have been found. Marine currents today however, carry driftwood from Alaska, Canada, and Russia along the northern Alaskan coast (Giddings, 1952) and may well have done so during deposition of the Gubik. Many of these types now do not grow north of the Brooks Range. Most fragments of shrubs and vascular plants are similar to those now growing in the area.

\section{SUBDIVISION OF THE GUBIK FORMATION}

Subdivision of the Gubik Formation can be attempted at present only on the basis of its general appearance and of limited observations of textural and mineralogic changes. Faunal successions within the Gubik have yet to be established, although four faunules have been delimited by MacNeil (1957, p. 100) from collections at six localities in the coastal plain west of the Colville River (fig. 10). These are: (1) Peard Bay, in part, and Kukpowruk River-Neptunea ventricosa soluta faunule, (2) Meade River-Neptunea ventricosa communis faunule, (3) Peard Bay, in part-Neptunea ventricosa clarki faunule, and (4) Colville River-Neptunea leffingwelli faunule. These faunules in the Gubik may or may not be given in ascending order. Considering the limited time span, indicated by geomorphic evidence, represented by the deposits and the similarity of species, much additional collecting and field study will be required before any succession can be utilized for subdivision of the formation. Although it is somewhat premature to establish members for the formation, an attempt is nevertheless made to distinguish the following facies or units (fig. 9) :

Barrow unit-poorly sorted to well-sorted mixtures of clay, silt, sand, and gravel ; unit grades from yellow, tan, and brown to black; in part, contemporaneous with and grades laterally into the Meade River sand and, in part, younger; rarely deposited directly on the Upper Cretaceous rocks; mostly marine; locally, in upper part, fluvial deposits and lacustrine deposits are characteristic.
Meade River unit-white, yellow, buff, or light-tan sand; generally clean and well sorted; marine; conformable to disconformable on the Skull Cliff unit, but in places deposited directly on the Cretaceous rocks. Locally, whipped into surface dunes; in the south and southeast commonly loesslike.

Skull Cliff unit-sticky or greasy, generally poorly sorted, blue-black to dark-gray, marine clay-silt-sandcobble unit; possibly glacially derived, in part, and deposited unconformably on the Upper Cretaceous rocks in much of the coastal plain west of the Colville River.

Correlation of MacNeil's faunules with these lithologic units is difficult. Faunule 1 is considered to be representative of part of the Barrow unit; faunule 2 is representative of the Meade River unit; faunule 3 is representative of the Barrow unit or possibly the Meade River unit; and faunule 4 is representative of the Skull Cliff unit.

The three units may be further subdivided locally, but areal correlation cannot be contemplated with present knowledge. By distinguishing these three units it is not inferred that each represents a distinct time unit in itself. To the contrary, as indicated in the description of the Barrow unit, an overlap of time is likely between it, and the Meade River unit. The slightly deeper and farther-from-shore sediments of the Barrow unit were probably deposited, at least in part when shallow near-shore seas were winnowing the Meade River sands; in places, these units interfinger. They grade laterally into each other and in places vertically. Near the contact shown on figure 9, they are only distinguished arbitrarily. The Skull Cliff unit however, is invariably covered with either the Meade River unit or the Barrow unit, except at Drew Point.

No attempt has been made to trace known horizons in the Gubik for more than a few miles. Consequently, the correlation of sections that are similar texturally or mineralogically may or may not be equivalent in time of deposition. Without question, transgressing and regressing seas reworked the older materials and had ample opportunity to deposit sediments of similar size, sorting, and composition at different times and different places or at different places at the same time; furthermore, unlike sediments were deposited contemporaneously as the shallow seas are doing today. The presence or absence of clay minerals and of gravel is used most widely in the author's correlation.

\section{SKULL CLIFF UNIT}

The Skull Cliff unit of the Gubik Formation is the basal or oldest subdivision. It is poorly exposed in the coastal plain west of the Colville River. The unit con- 
sists dominantly of clay and silt, ranging from dark gray to blue black when wet. It has a sticky to greasy feel and has undergone more induration (although slight) than the upper units. Its unconformable relation to the Upper Cretaceous rocks and conformable to disconformable relation to the overlying sediments are best seen at Skull Cliff, the type locality, and northeastward along the coast. The disconformable contact is a sharp lithologic break in several places, with slight erosion of the top of the unit.

Localities where the unit is known to be present are shown on figure 9. A sketch map of the Barrow area (fig. 11) shows depths to the top of the unit. The
Bay. The gravel and cobbles are dominantly chert, sandstone, and quartzite, but granite, marble, diorite, and other rock types are present. They are rounded to angular. The sand and silt sizes are dominantly quartz and chert of several generations; well-rounded to angular grains are equally abundant in places. The clay minerals have not been identified. A wide range of accessory minerals occurs in most outcrops. Marine microfossils and megafossils are sparse in most beds but are concentrated locally in coarse layers. Bedding is faint in most outerops but is moderately well defined in many exposures at Drew Point (fig. 13) where it is horizontal and slightly wavy or undulating. The clay-

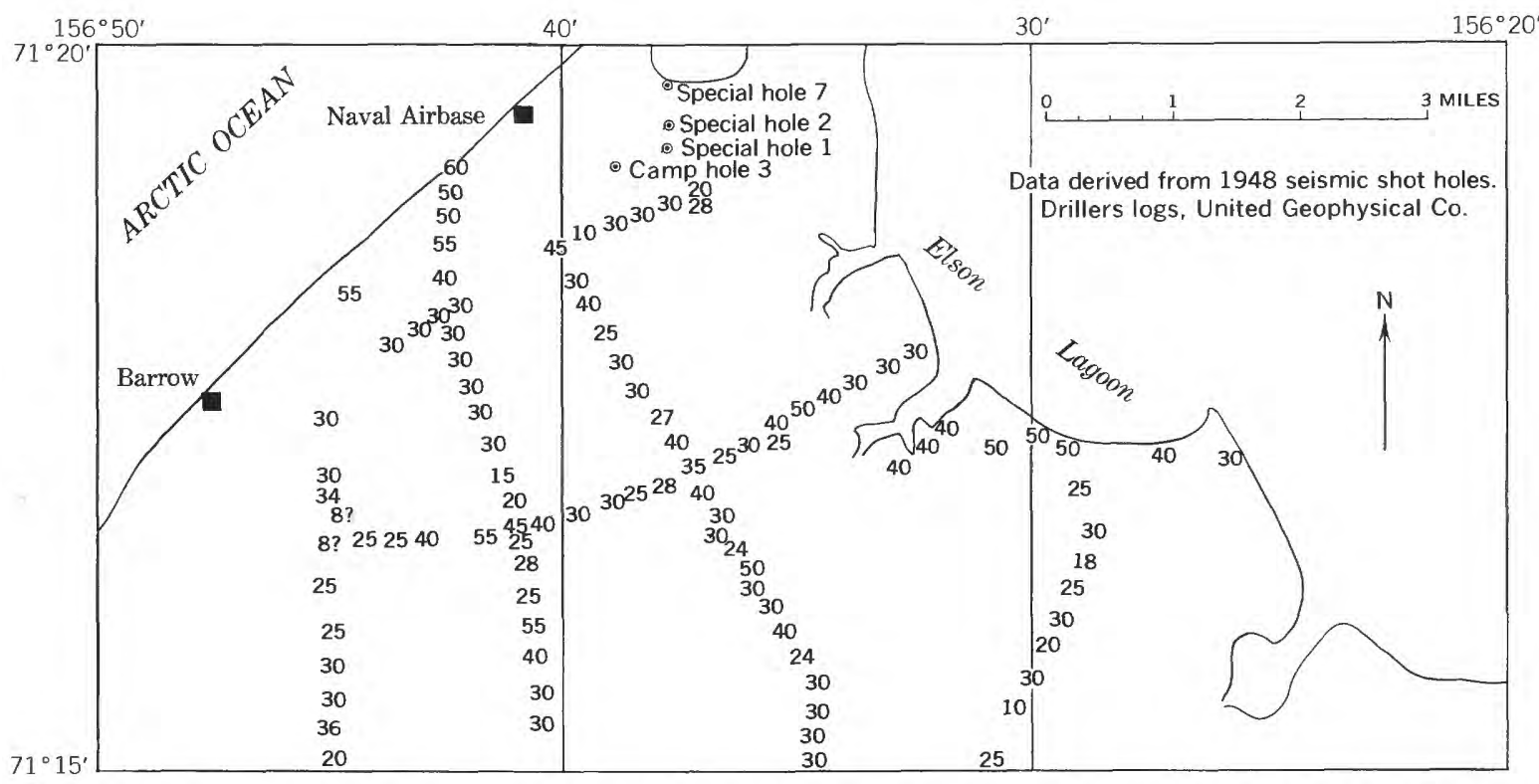

Frourm 11.- Sketch map of the Barrow area, showing location of drill holes and depth, in feet from the surface, to the top of the Skull Cliff unit of the Gubik Formation.

Skull Cliff unit presumably underlies most of the northern and western parts of the coastal plain west of the Colville River; although it was not seen in the southeastern part and precise locations are unknown, well drillers have reported a maximum thickness there of 20 feet under 180 feet of the Meade River unit. The greatest observed thicknesses are about 15 feet at Skull Cliff and 20 feet near Drew Point; the unit is generally less than 10 feet. At Skull Cliff and at Mitlitavik a few inches to 1 foot of residual weathered sand from Cretaceous sandstone lies directly under the unit. A thicker "weathered soil zone" observed along the Meade River by Webber (1947, p. 9-10) is arbitrarily included in the unit.

The composition of the unit varies widely both locally and regionally. Sand, gravel, and cobbles are typical constituents at Walakpa (fig. 12), Skull Cliff, Mitlitavik, Christie Point, Nunavak, and Admiralty

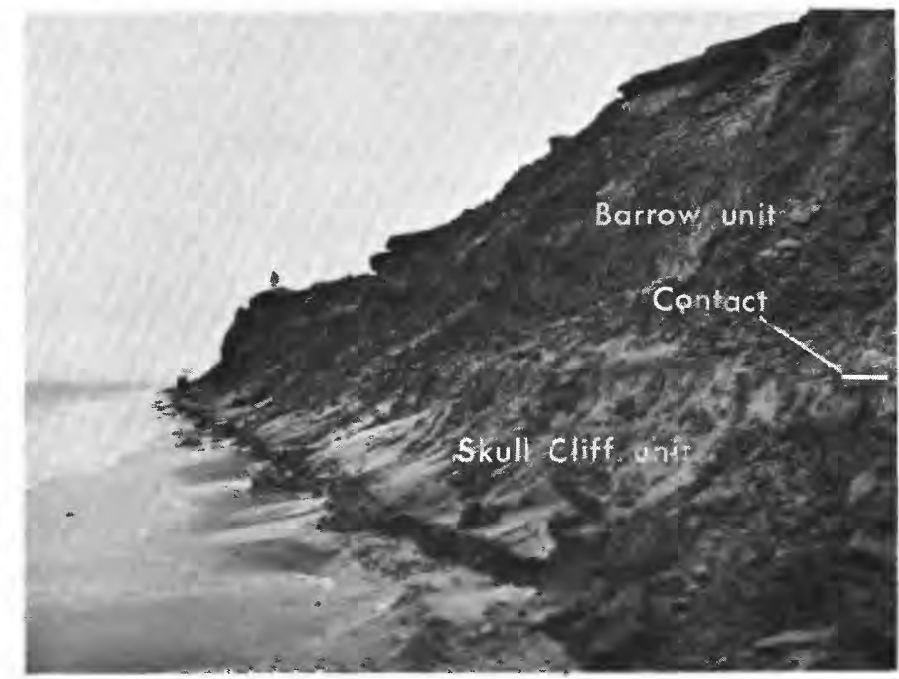

Figure 12.-Coastal bluff 1.5 miles northeast of Walakpa, showing 6 feet of marine dark-gray clay of the Skull Cliff unit of the Gubik Formation overlain by marine silts and sands and by fluvial-lacustrine deposits of the Barrow unit. August 21, 1950. 


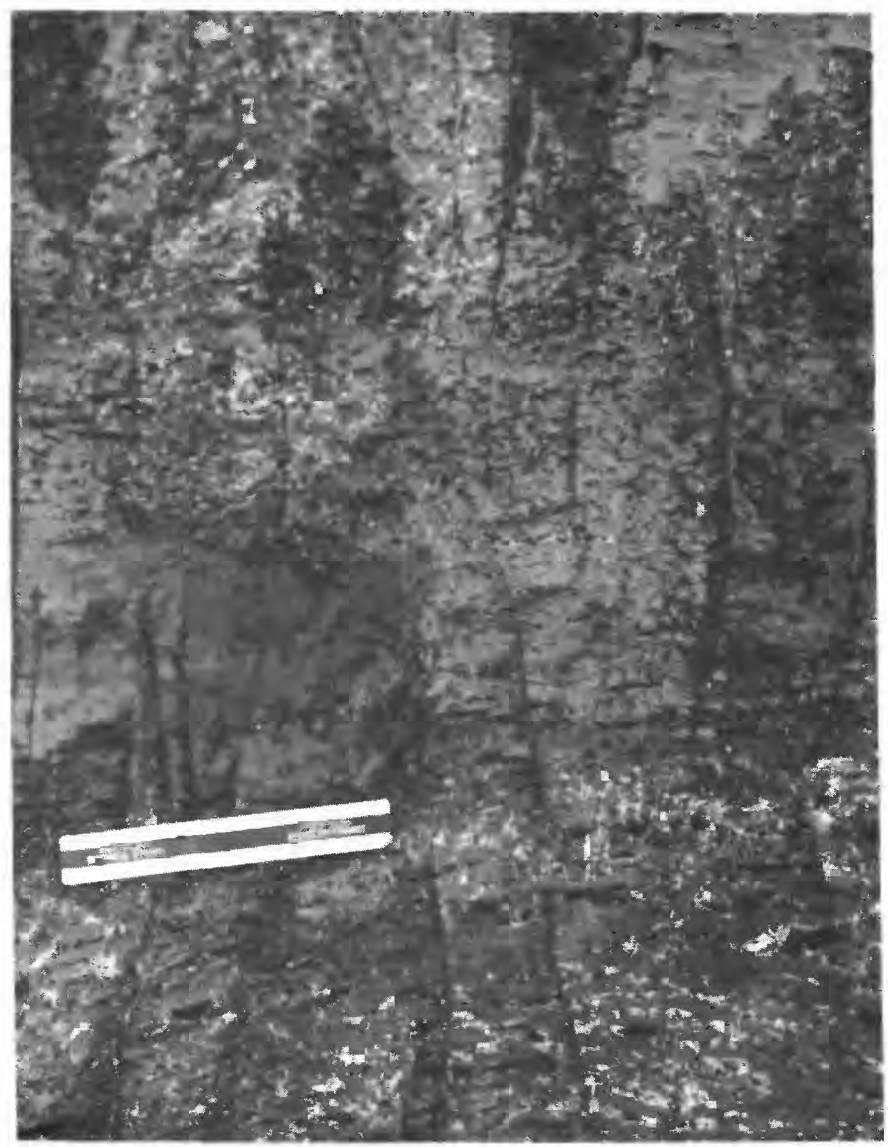

Figdre 13.-Marine clayey silt and silty clay of the Skull Cliff unit of the Gubik Formation showing ice. isix-inch scale. Locality about 1,300 feet east of Drew Point. silts are commonly blocky; in places they are fissile. Sorting is poor (figs. 14 and 15).

The environment of deposition is marine in most localities visited by the writer. Silica, "rock flour"(?), which is abundant locally, erratic cobbles, poor sorting, and greasy feel all suggest some affinity to glacial till. The presence of feldspars, amphiboles, calcite, and other more easily weathered minerals, of marine fossils, and of erratic cobbles precludes the hypothesis that this unit is a weathered soil as proposed by Webber (1947, p. 910). However, the author has not observed the outcrops described by Webber along the Kuk and Meade Rivers, and it is possible there that advancing seas only slightly reworked a post-Cretaceous soil horizon. The presence of several inches of residual weathered sand unconformably underlying the unit at Skull Cliff and Mitlitavik shows that reworking was not accomplished every where.

\section{LOCALITY DESCRIPTIONS}

SKULL CLIFF

On September 5, 1947, a brief visit was made to the Skull Cliff area. At a point about 30 miles southwest of Barrow, 15 to 20 feet of crossbedded fine- to mediumgrained consolidated gray sandstone of Cretaceous age crops out at the base of the bank. Unconformably overlying this sandstone is 1 to 15 feet of dark-gray sticky silty clay containing pebbles of granite and chert as much as 4 inches in diameter. This area is considered the type locality for the Skull Cliff unit. The silty clay

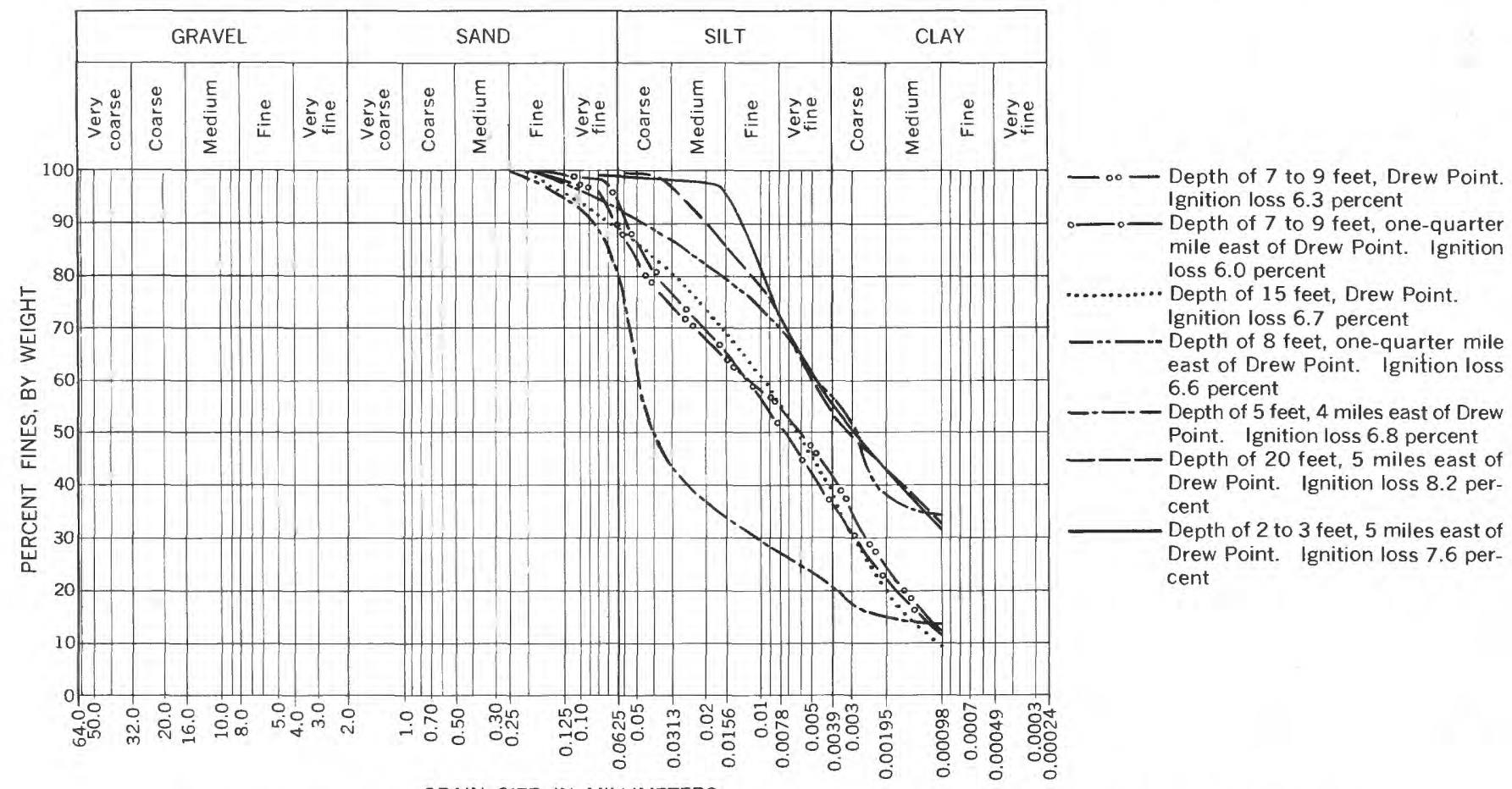

GRAIN SIZE, IN MILLIMETERS

Figdak 14.- Size-grade cumulative curves of the Skull Cliff unit of the Gubik Formation from Drew Point area. 


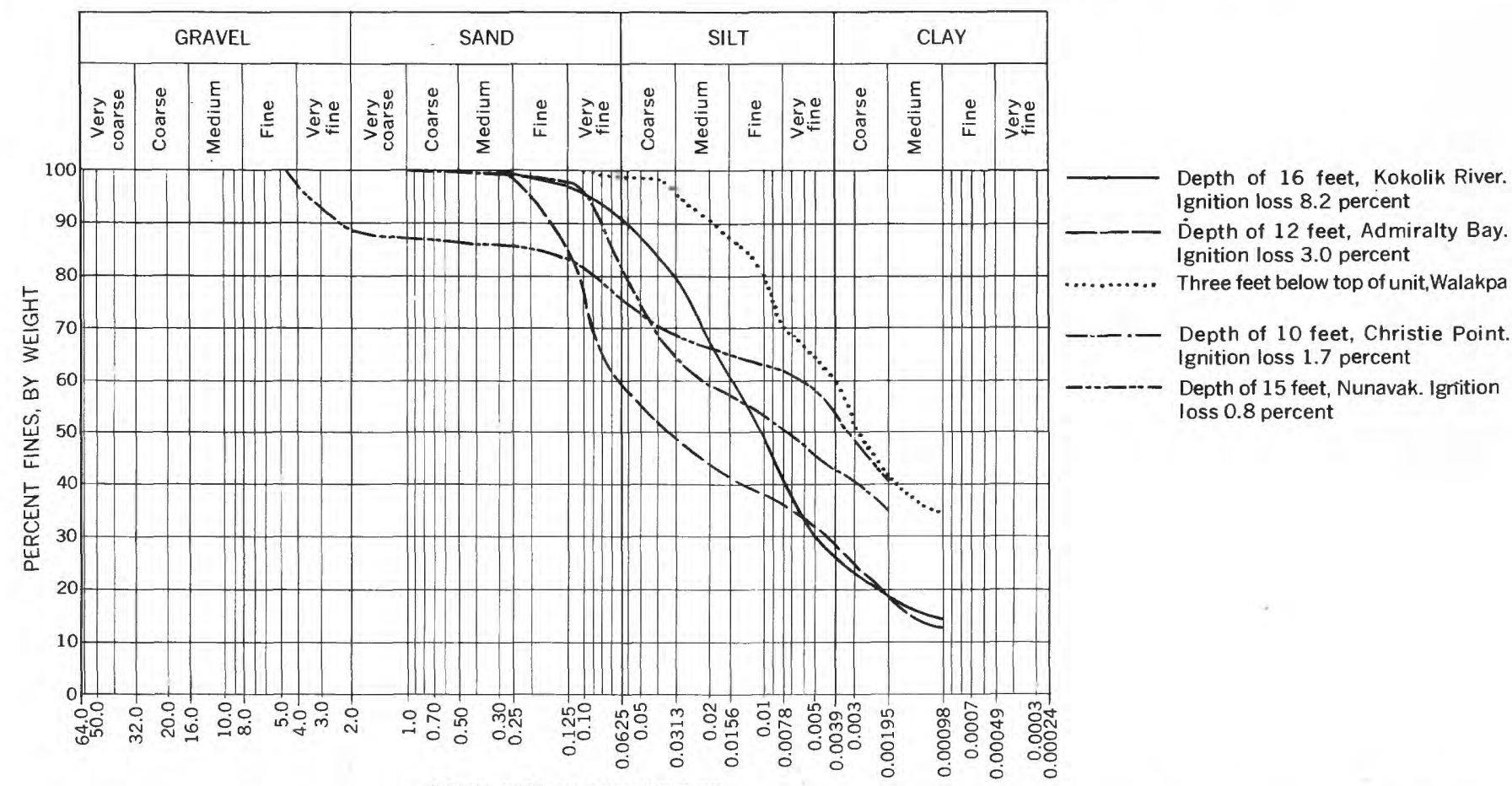

GRAIN SIZE, IN MILLIMETERS

FIGURE 15.-Size-grade cumulative curves of the Skull Cliff unit of the Gubik Formation from Kokolik River, Admiralty Bay, Walakpa, Christie Point, and Nunavak.

varies markedly in texture vertically and horizontally. The top of the unit is fairly level; the unit thickens and thins as it fills the uneven top of the sandstone. The clay is blocky in some places and fissile in others, and becomes more silty and sandy upward. It is very poorly sorted and in part resembles a marine-deposited till. Granite and gray to red marble erratics as large as 2 feet in diameter were seen at the base of the bank, where they seemingly were left behind after removal of the finer clastics.

\section{DREW POINT}

At Drew Point, 70 miles southeast of Barrow, and in the coastal bluff eastward for 5 miles from the point, the Arctic Ocean is rapidly eroding the perennially frozen sediments that rise as much as 23 feet above sea level. The lowermost sediments are marine silty clays and clayey silts (fig. 14), which are generally dark gray, blue black, greenish gray, or dark brown but which have yellow to tan blotches and irregular streaks and patches. Stratification, most ice veinlets, large fragments of organic matter, and most textural changes transect the contact of the colors. Ice in grains, granules, veins, dikes, and small irregular bodies (fig. 16) makes up 25 to 60 percent of the sediment by weight. Silt- and clay-sized particles are about equally abundant; very fine sand is less than 10 percent. Organic matter makes up 6 to 8 percent of the total weight. In places the sediments are extremely gummy and tacky.
Various clay minerals, fragments of minerals of clay size, and quartz and chert of silt and sand sizes are most abundant in the marine sediments. Orthoclase, plagioclase, muscovite, biotite, chlorite, epidote, garnet, calcite, sphene, zircon, magnetite, ilmenite, tourmaline, glaucophane, hornblende, pyroxene, and other minerals are present. Most are fresh and angular; only the heavier accessories are well rounded.

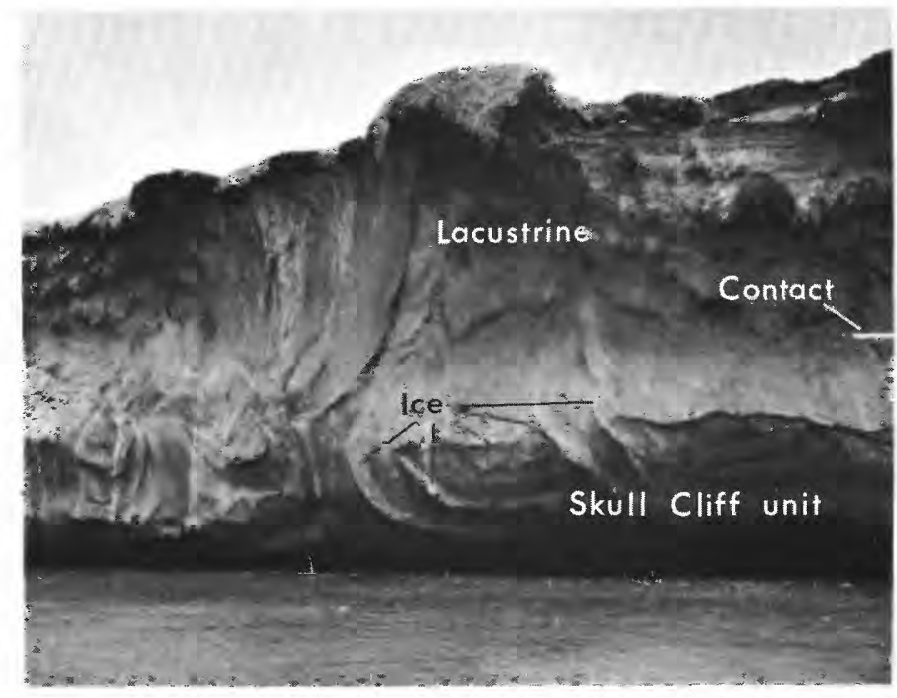

Figure 16.-Ice in marine clay-silts of the Skull Cliff unit of the Gubik Formation below and lacustrine deposits with peat above in a 23-foot bank about 5 miles east of Drew Point. August 7, 1950. 
The marine sediments are cut into by thaw lakes, some of which extend to sea level, but most penetrate only a few feet. They leave characteristic deposits, readily distinguishable from the underlying marine deposits by their color, bedding, and sorting of the material. The lake sediments have much greater organic content and large undecayed woody fragments, comminuted tissues, and roots of water-loving plants in place. The reworking of the sediments only slightly increases the weathering of some of the feldspars and other minerals. Shapes commonly remain angular in the lighter fractions; the accessories were previously rounded. The composition generally remains the same, although, of course, locally sorting results in redistribution of certain minerals so that their percentage in any one spot is altered.

\section{MITLITAVIK}

At the lagoon immediately south of Mitlitavik 1 foot of dirty gray clayey silt in places overlies the Cretaceous sandstone. The silt contains mostly quartz and chert, but weathered angular orthoclase, angular garnet, and well-rounded rutile and zircon were seen. Most grains were coated with iron oxides.

Where the Cretaceous sandstone does not appear above sea level, at least 8 feet of dark-gray to blue-black sticky silty clay was seen. The clay unconformably underlies yellow sand of the Meade River unit. Most of the clay minerals have an index of more than 1.54 but were not identified. Quartz, chert, magnetite, and small fragments of other minerals were seen in the clay.

\section{KOKOLIK}

On August 30, 1947, a sample of dark blue-gray to black massive clayey silt (fig. 15) was collected from the eroding bank of the Kokolik River at about lat $69^{\circ} 40^{\prime} \mathrm{N}$. and long $161^{\circ} 55^{\prime} \mathrm{W}$. The clayey silt was exposed vertically for 8 feet above river level and was capped by 12 feet of fluvial-lacustrine(?) mud and organic matter containing much ice. The clayey silt is faintly stratified horizontally and texturally and mineralogically resembles other silts of the Skull Cliff unit. Clay, clay-size minerals, quartz, and calcite are dominant. Chlorite, muscovite, zircon, sphene, magnetite-ilmenite, and other minerals are present. No fossils or pebbles were seen in the small exposure.

\section{NUNAVAK}

On August 10, 1946, one sample was collected from the Skull Cliff unit, 9 feet above sea level (or depth of $16 \mathrm{ft}$ ) in the coastal bluff at Nunavak, 5.5 miles southwest of Barrow. The base of the bluff was covered to a height of 6 feet by the beach deposits. The base of the section exposed 6 feet of gray blocky clay and lenses of yellow clay, both containing admixed silt, sand, and well-rounded pebbles. The clay is overlain conformably by 8 to 13 feet of the Barrow unit. A cumulative curve is shown on figure 15. The mean size is 0.0031 $\mathrm{mm}$, and the sorting coefficient is more than 8.7. Clay is the most abundant material, but well-rounded pebbles of black chert, brown quartzite, red quartzite, and red granite as much as one-half inch in diameter are present. The clay-size particles seem to be composed largely of minute angular silica fragments; some kaolin-illite is indicated by the index of refraction. The sand-size particles are composed mostly of angular fragments of cloudy chert, but some clear angular quartz and scattered grains of garnet, andesine, and magnetite-ilmenite were also seen. Organic content of the sample is 0.8 percent. Parts of the clay and some quartz and chert grains are iron stained. No mega- or microfossils were seen. The sediment is slightly calcareous.

CHRISTIE POINT

During August 18-20, 1946, a sample of the gray sandy clayey silt (fig. 15) of the Skull Cliff unit was collected from a depth of 10 feet in the lagoonal bank about 2 miles northwest of Christie Point and 25 miles southeast of the Barrow airbase. The bank, locally called Katchicksuk Bluff, rises to a maximum of 20 feet above sea level and exposes 11 feet of the Skull Cliff unit capped by 9 feet of yellow- and greenish-brown sandy clayey silt of the Barrow unit. The contact is gradational over a range of several inches but apparently conformable. The mean particle size of the gray sandy clayey silt (Skull Cliff unit) is $0.008 \mathrm{~mm}$; sorting coefficient is greater than 7.7. Except for distinct lenses of gravel, the largest particle size is $1 \mathrm{~mm}$. Gravel lenses are composed of : well-rounded to angular pebbles, as much as 2 inches in diameter, consisting- of black, brown, and yellow chert; red, brown, white, and yellow quartzite; red granite; hornblende granite or diorite; cream and red sandstone; black slate; vuggy vein quartz and sandstone; coarse-grained dolomite; and other rock fragments. These lenses are as much as 10 inches thick. They also contain numerous fragments of pelecypods and possibly other marine organisms. Clay minerals or particles of clay size are common in the silt; organic content is 1.7 percent. The silt and sand fractions are composed dominantly of quartz and chert in angular to well-rounded grains. Most grains are coated with clay and carbonate, which are stained by iron oxides. Chlorite is present and ilmenite common. Wave action has concentrated gravel and coarse sand into a veneer over muck in a narrow beach along the bank. 


\section{MEADE RIVER UNIT}

The Meade River unit, shown on figure 9, covers more than half the total area of the coastal plain west of the Colville River. It is the most uniform unit within the Gubik and is invariably light colored. Two facies are recognized: a clean well-sorted marine sand (fig. 17), whose surface has been whipped into dunes; and a fairly clean well-sorted uniform silt of mixed origin, commonly resembling loess (fig. 18). From 62 to 83 percent of the grains lies in the range of 0.01 and $0.05 \mathrm{~mm}$ in diameter. The sand occupies the central part of the coastal plain west of the Colville River, especially around the middle parts of the Meade and Ikpikpuk Rivers. The silty sediment predominates in the southern and southeastern part of the coastal plain and along the Colville River. These facies seem to grade laterally into each other over distances of several miles, although

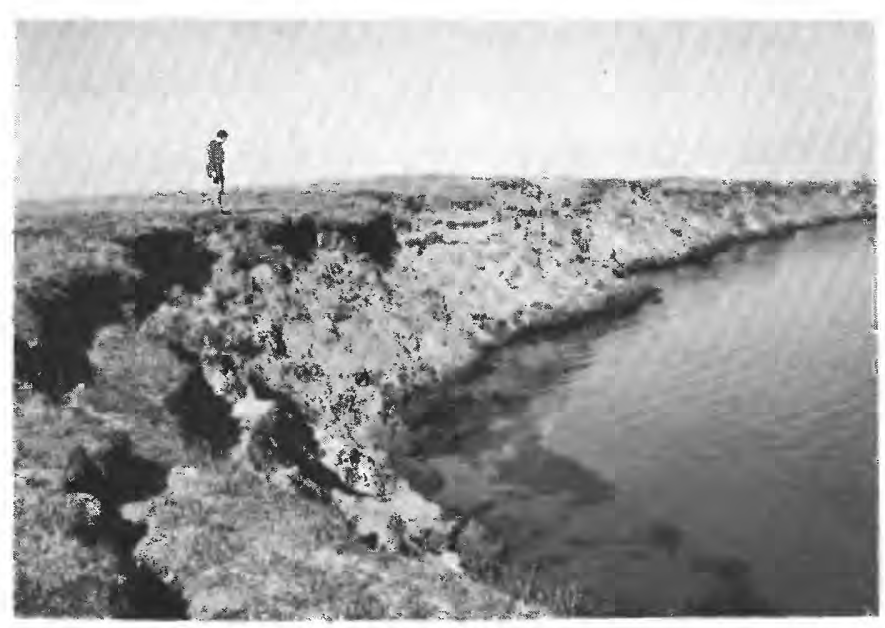

Frgure 17.-Sand of Meade River unit of the Gubik Formation exposed in the 30 -foot bank of the lake at lat $70^{\circ} 28^{\prime} \mathrm{N}$, and long $157^{\circ} 55^{\prime} \mathrm{W}$. August 25, 1947.

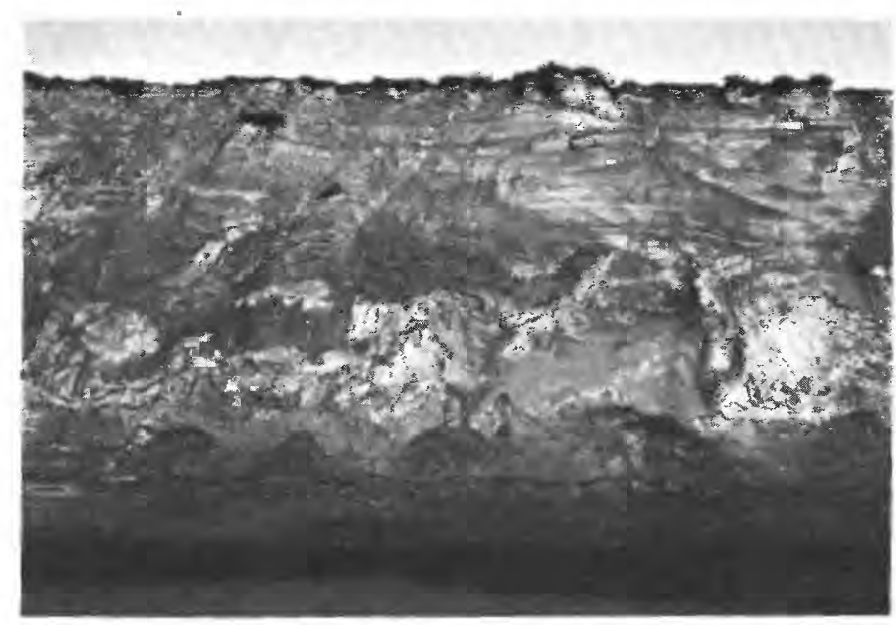

Frgure 18.- Sandy clay-silt of the Meade River unit of the Gubik Formation in a 50-foot bank near the headwater of the Topagoruk River, lat $70^{\circ}$ N. and long $156^{\circ} 10^{\prime} \mathrm{W}$. August 15, 1947 . their relationships are not clear. To the west and north the Meade River unit becomes more variable texturally, and grades laterally into the Barrow unit. The contact of the Meade River unit on the Skull Cliff unit was seen at Mitlitavik, Kuk and Meade Rivers, Admiralty Bay, and Ocean Point.

The maximum reported thickness of the Meade River unit, 180 feet, is near lat $70^{\circ} \mathrm{N}$. and long $153^{\circ} 35^{\prime} \mathrm{W}$.; the unit is generally several tens of feet to 100 feet thick. It pinches out to the south against the foothills, or it grades laterally into the surficial soil and valley bottom mucks of the foothills. The soils along the north edge of the foothills have presumably resulted largely from frost action and eolian processes; they have worked downslope by masswasting and are several tens of feet thick in the valleys but are generally only a few inches thick on the uplands. Locally, at the boundary between the coastal plain and the foothills, they may be several tens of feet thick. Probably they are related in mode of origin at least in part to the loesslike materials in the Meade River unit to the north.

Except for zones that grade north and west into the Barrow unit and the local coarse sands and basal conglomerates in the lower part, most sediments of the Meade River unit are very well sorted (figs. 19-23); sorting coefficients generally range from 1.2 to 1.6 . Median size of the grains ranges from medium sand to silt, but such changes generally take place over distances of many miles. Recent reworking of the upper part by streams, thaw lakes, and eolian activity may change the textural classifications of local samples. Stratification is not well defined except in the northern parts of the unit, where horizontal, wavy, or undulating beds are common. In other places cross-stratification is characteristic. In places in the silts varvelike beds may be seen in deposits interpreted as lacustrine. Massive, structureless sections seem to be common in the sand of the central part of the coastal plain, but slumping obscures most details.

The unit is dominantly quartz and chert. It is obvious that many generations of these minerals are represented, as indicated by the range from well-rounded, pitted, frosted, polished, or stained grains to clear euhedral crystals and unmodified angular fragments. Accessory minerals are absent locally, but a wide range of types is generally present. Only rarely are marine fossils found, and these are more common in the northern, more variable parts of the unit. Lacustrine fossils are particularly abundant in the upper part that had been reworked by former lakes. Bits of well-preserved shrubs are common throughout the section, but total organic content is low. Dark tones characteristic of abundant organic matter in the other units are conspicuously absent. 


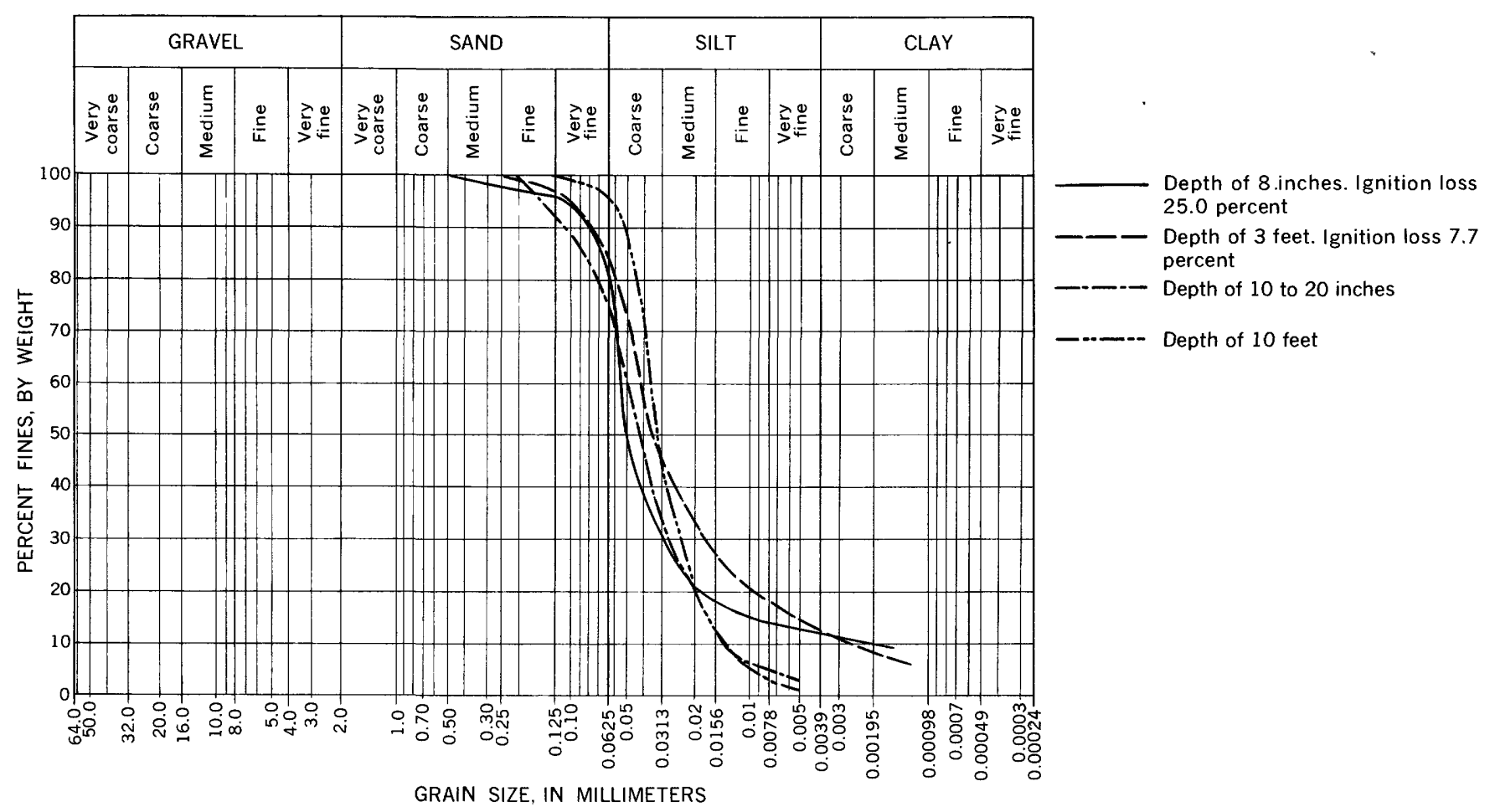

FigdrI 19.-Size-grade cumulative curves of the Meade River unit of the Gubik Formation from Sentinel Hill.

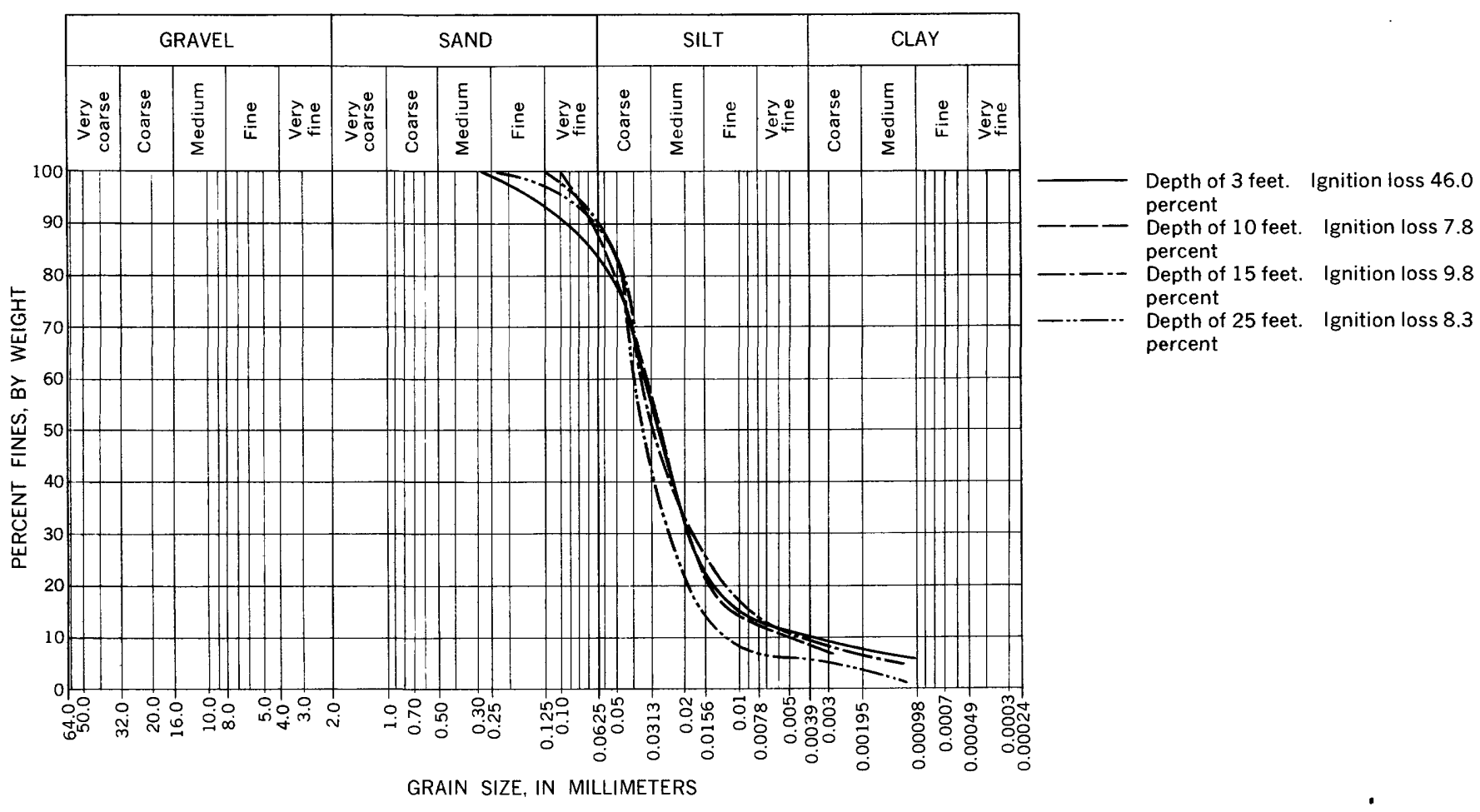

Fradrm 20.-Size-grade cumulative curves of the Meade River unit of the Gubik Formation from the Topagoruk River. 


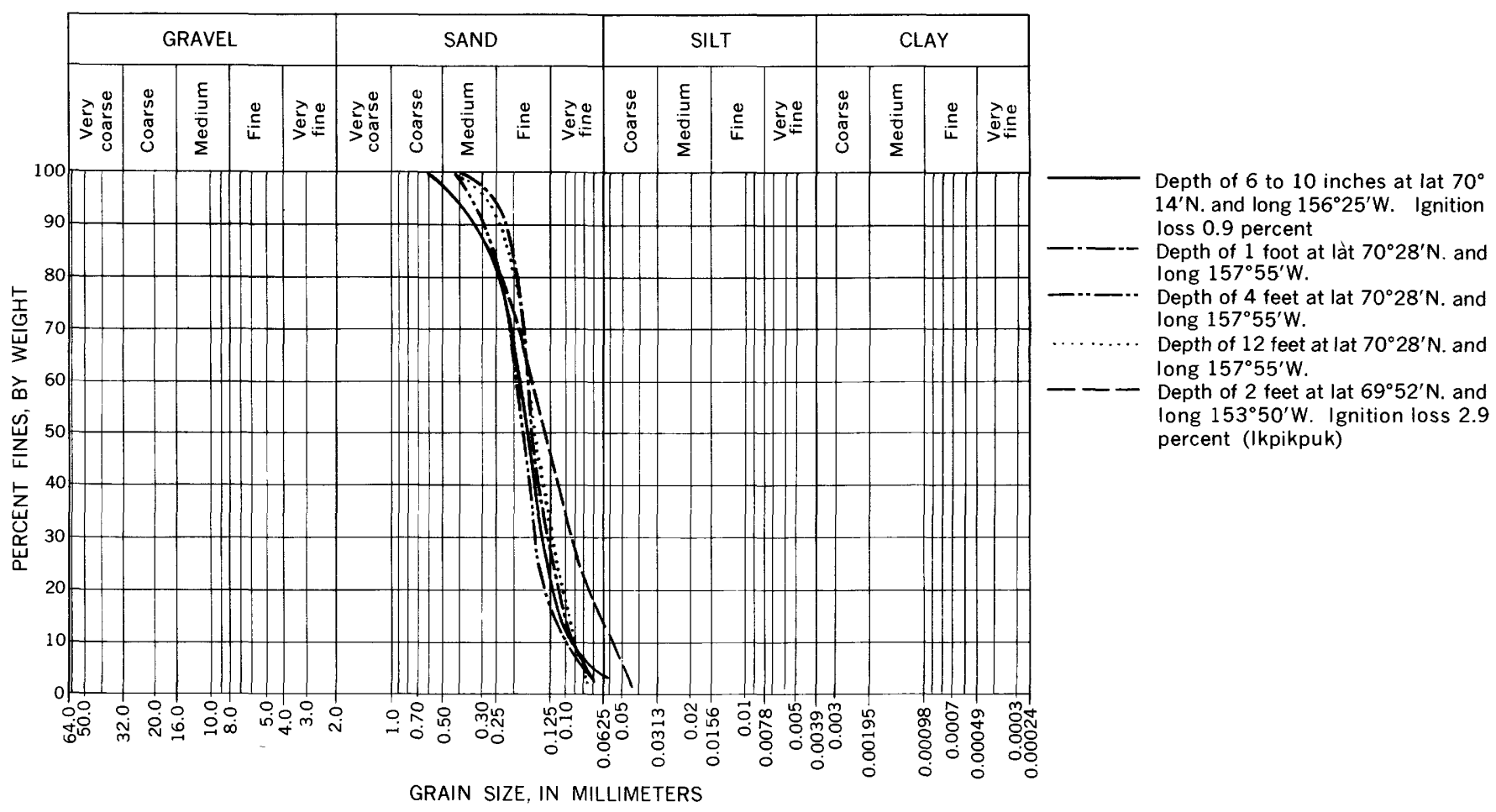

Figure 21.- Size-grade cumulative curves of the Meade River unit of the Gubik Formation from the central part of the coastal plain and Ikpikpuk.

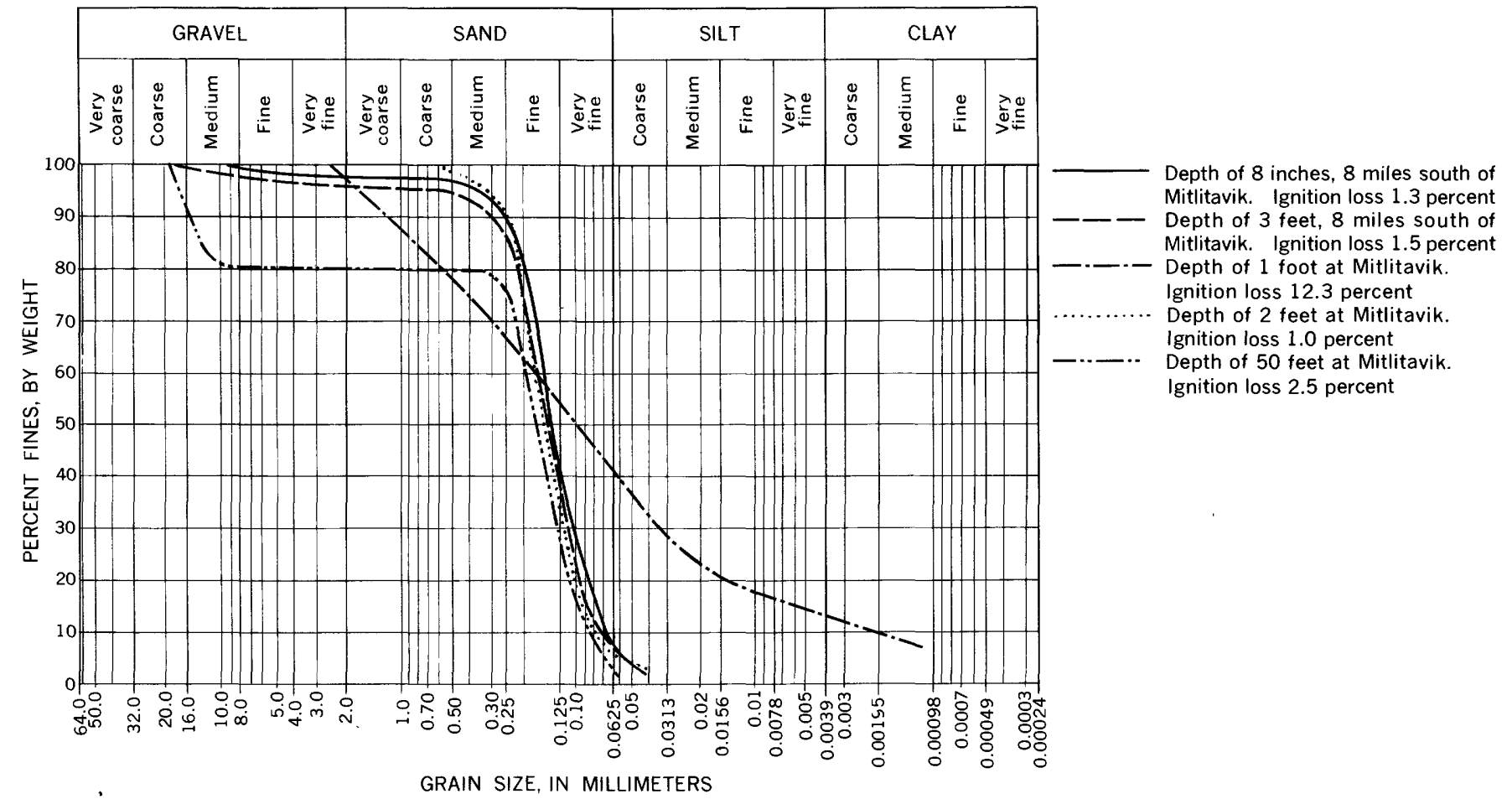

FiguRD 22.-Size-grade cumulative curves of the Meade River unit of the Gubik Formation from the vicinity of Mitlitavik. 


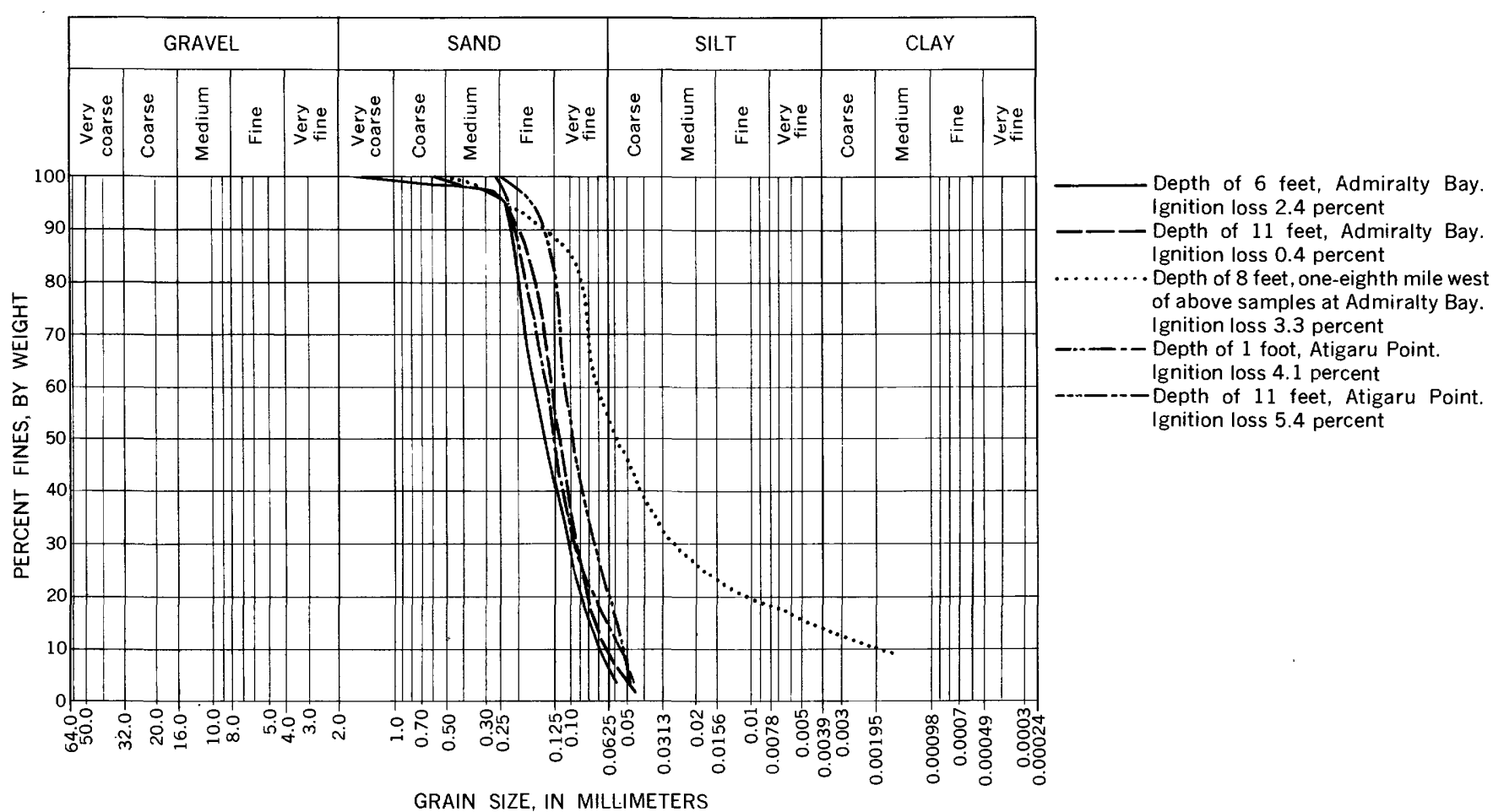

Fradre 23. - Size-grade cumulative curves of the Meade River unit of the Gubik Formation from Admiralty Bay and Atigaru Point.

LOCALITY DESCRIPTIONS

SENTINEL HILI

From Sentinel Hill on the Colville River, 45 miles below Umiat, westward to the Meade River and the head waters of the Kuk River, loess or loesslike material is as much as several tens of feet thick along the boundary between the coastal plain and the Arctic foothills. It is not present everywhere and overlies and apparently grades laterally into the sandy facies of the Meade River unit, but the relationship is not clear. More than 50 percent of the component particles of the silt are commonly between 0.01 and $0.05 \mathrm{~mm}$ in diameter. The silt is tan, buff, cream, or light yellow brown, calcareous, and is generally massive and structureless. On slopes where solifluction is effective, and in some other places, pseudobedding or true bedding may be found. In places, well-rounded polished or frosted chert pebbles as much as one-fourth inch in diameter are scattered through the deposit. In many places streams have cut deep valleys into the deposits, which are thicker in the valleys than on hills.

Seven samples were collected August 10, 1947, from the top of the bluff 7 miles south of Sentinel Hill. Four of the samples were analyzed mechanically (fig. 19). They have median sizes of 0.031 to $0.05 \mathrm{~mm}$ and sorting coefficients of 1.4 to 2.1, although the sample having the sorting coefficient of 2.1 was obviously derived from a solifluction lobe in which material was moved a con- siderable distance and mixed with sand from below. Although much organic matter is contained in the samples from the active layer (the first and third curves on fig. 19), the samples are calcareous and most grains are fresh. Mineral fragments are well rounded to angular and obviously of several generations. Quartz and chert are dominant; tourmaline, sphene, zircon, amphibole, pyroxene, calcite, epidote, olivine, rutile, garnet, and hypersthene were identified tentatively, and other minerals are present.

\section{TOPAGORUK}

Paige, Foran, and Gilluly (1925, p. 20-21) mentioned that Pleistocene marine deposits of quartz sand, mud, and layers of coaly debris containing thin layers of marine shells rest unconformably upon the eroded surface of Mesozoic sandstone and shale and extend inland for 20 miles or more, except in a few places where low hills rise above the general level of the plain. Inland, the marine sand merges with Pleistocene fresh-water sand and gravel. Gilluly collected a fresh-water Pleistocene fauna from those deposits at a point about 60 miles inland on the Topagoruk River.

On August 15, 1947, a section of the loesslike material exposed in the headwaters of the Topagoruk River, about lat $70^{\circ} \mathrm{N}$. and long $156^{\circ} 10^{\prime} \mathrm{W}$., was examined briefly. Banks rising about 80 feet above the stream were so obscured by slump that detailed sections could 
not be measured. At one place it seemed that the lowermost 20 feet of the section was composed of silt with clay, fine to very fine sand, and pebbles of chert and gray sandstone; the upper 60 feet was dominantly silt, of which the uppermost 10 feet was exposed. The transition from the lower sandy zone to the upper silt took place vertically within a range of about 3 feet. Locally, faint horizontal beds and crossbeds containing pebbles and organic matter were observed in the lower zone; the upper zone showed faint crossbeds in which there was virtually no change in material. Woody fibers were seen throughout the section. One sample at a depth of 3 feet and another at a depth of 10 feet were analyzed mechanically (fig. 20). The median grain size is 0.028 and $0.027 \mathrm{~mm}$; the sorting coefficient is 1.6 ; and 62 percent of the grains in one sample and 73 percent of the grains in the other are between 0.01 and $0.05 \mathrm{~mm}$ in diameter. Grains are well rounded to angular, frosted, and fresh. Quartz (including clear doubly terminated, euhedral crystals), chert, tourmaline, apatite, green garnet, muscovite, sphene, zircon, magnetite, amphibole, and pyroxene were tentatively identified; other minerals are present.

A few hundred feet from the aforementioned site and under a drained lake, about 50 feet of silt is exposed (fig. 18). The silt is distinctly stratified horizontally; downwarped strata at the surface of the streambank is attributed to slump and creep. Bedding planes are set apart by layers of clay-rich or organic-rich laminae alternating with very fine to fine sand and silt. In places it is almost varvelike. Crossbedding is a very minor feature. No pebbles were seen, but thin-shelled lacustrine(?) gastropods were scattered throughout the upper 15 feet, where bedding is better defined. Figure 20 shows a cumulative curve of a sample from a depth of 25 feet in the section shown on figure 18. The median size is $0.027 \mathrm{~mm}$, the sorting coefficient is 1.2 , and 83 percent of the material is between 0.01 and $0.05 \mathrm{~mm}$ in diameter. Another sample (fig. 20) from a depth of 15 feet has a median size of $0.028 \mathrm{~mm}$, a sorting coeffcient of 1.6, and 68 percent of the material is between 0.01 and $0.05 \mathrm{~mm}$ in diameter. Two other samples, at depths of 25 and 35 feet, are similar. All the samples are calcareous and woody fibers are common. The grains, some of which are frosted, consist of many types and are well rounded to angular and fresh.

\section{Central coastal PLAIN}

North of the narrow belt of loess or loesslike deposits and west of the Colville River is an area of dunes belonging to the Meade River unit. Rounded grains of quartz and chert, which are yellow, tan, bluff, or light brown, compose the bulk of the material. Magnetite, ilmenite, volcanic glass(?), rutile, zircon, orthoclase, plagioclase, and other minerals are present in small amounts. The composition varies from place to place, but few data are available. One sample collected $\mathrm{Au}$ gust 15,1947 , from a dune at lat $70^{\circ} 14^{\prime} \mathrm{N}$. and long $156^{\circ} 25^{\prime} \mathrm{W}$., is typically composed of fine sand (fig. 21 ). The sorting coefficient is 1.3. Such dune areas are distinguished more by the distinctive cover of lichens, like Alectoria, and dark vascular plants, like Cassiope tetragona, than by a change in lithology of sediments. Similar sands were collected August 25, 1947, from the lake bank (fig. 17) at lat $70^{\circ} 28^{\prime} \mathrm{N}$. and long $157^{\circ} 55^{\prime}$ W. (Black and Barksdale, 1949, pl. 5D). The mechanical analyses of samples from depths of 1,4 , and 12 feet are shown on figure 21. Median grain size is $0.16,0.19$, and $0.16 \mathrm{~mm}$; sorting coefficients are 1.3. These samples were lost prior to microscopic examination but megascopically resembled other samples from the Meade River unit. In the field only the upper 2 feet of the deposit displayed typical dune structures and appeared to be wind deposited. The deposit overlies 1 foot of turf and organic̈-rich sand, which in turn overlies white, buff, and light-yellow fine sand extending from depths of 9 feet to lake level. The lower sand is clean and generally contains rounded grains. The unit is horizontally bedded, as if water laid. Bits of organic matter are scattered throughout.

\section{MITLITAVIK}

Aqueous or eolian sands similar to those in the central coastal plain extend westward but are mixed with other sediments in more complex sections. At the south end of the lake 8 miles south of Mitlitavik, a 10-foot section of fine yellow sand (fig. 22) is composed almost entirely of quartz and chert. In the lagoon south of Mitlitavik similar sands are interbedded with other sediments over the Cretaceous rocks. At the surface of the lagoonal bank clayey, silty sand (fig. 22) containing much organic matter makes up the active layer, 20 to 30 inches thick. Only quartz, chert, and clay are present. Immediately below is fine clean yellow to tan sand (fig. 22 ), which is texturally identical with the sand to the east. Stratification is horizontal although poorly defined. Most of the section is partly obscured by slump, and details cannot be given. The slumped material indicates that similar sand extends to the lowermost part of the section. At a depth of about 50 feet, or about 10 feet above sea level, similar fine sand containing pebbles of fine to medium gravel was collected (fig. 22 ; the sample was weighted in favor of pebbles). The sand is largely quartz and chert; magnetite, ilmenite, olivine, rutile, orthoclase, calcite, sphene, plagioclase, hornblende, zircon, monazite, garnet, and other 
minerals are also present. The pebbles are dominantly chert or siliceous rocks. All pebbles are well rounded and polished. The flinty gray pebbles are characterized by percussion rings. The sand grains are mostly subrounded, but range from well rounded to angular. Another sample was collected at a depth of about 52 feet, 2 feet above consolidated Cretaceous sandstone and 8 feet above sea level. It is identical to the first sample mentioned.

\section{ATTGARU POINT}

A brief visit on August 29, 1947, to Atigaru Point, Harrison Bay, revealed a 12-foot section of fine to very fine yellow to tan sand containing scattered pebbles of chert as much as one-fourth inch in diameter and numerous Foraminifera and fragments of pelecypods and gastropods. Macoma balthica (Linné) and $M$. incongrua Martens were identified by F. Stearns MacNeil (written communication, January 4, 1957). Stratification is horizontal and slightly undulating, as shown by thin laminae of gray to brown silt and clay. These laminae are more abundant in the lower part of the section and tend to impart a brown color to the sand. In places at the base of the section the yellow sand grades into a dark-gray silty sand, which occurs apparently along the gradational and interfingering contact of the contemporaneous parts of the Meade River and Barrow units of the Gubik.

At a depth of 6 to 10 inches in the active layer on top of the bank, only quartz, chert, and clay minerals were seen; carbonates and other more easily soluble minerals had been destroyed, and eolian (?) silt had been added to. the soil profile. The material is less well sorted than that underlying it in the permafrost. At a depth of 12 inches in the active layer near the edge of the bank, wellrounded to angular grains of quartz and chert and rounded grains of rutile, monazite, titanite, zircon, magnetite, apatite, chloritoid, staurolite, and other accessory minerals were seen. The sand is well sorted (fig. 23). At a depth of 7 feet in similar sand, Cribroelphidium arcticum Tappan, Elphidiella sibirica (Goes), and other Foraminifera are common; fragments of other marine shells also occur. Identical sand was found at a depth of 11 feet (fig. 23). Pebbles eroded from the bank and concentrated on the beach were mostly siltstone, sandstone, and quartzite; granitic, diabasic, and chert pebbles are also present.

\section{IKPIKPUK}

Near the head of the Ikpikpuk River, at lat $69^{\circ} 52^{\prime} \mathrm{N}$. and long $153^{\circ} 50^{\prime} \mathrm{W}$., two samples of clean white, yellow, and buff sand of the Meade River unit were collected on September 4, 1947, from the 30-foot bank of a lake. The sands display faint horizontal stratification. Caving banks obscure the details of the section. One of the two samples, taken from a depth of 4 feet in the lake bank, and a third taken from 2 feet beneath a lake bed 2 miles distant are virtually identical. Both are very fine to fine-grained sand (fig. 21), white, light yellow to buff, clean, and highly calcareous. Grains of quartz and chert of several generations compose the bulk of the material; they are well rounded for the most part, but angular grains are present. Well-rounded to angular calcite composes 2 to 4 percent (estimated), and magnetite, zircon, rutile, epidote, plagioclase, orthoclase, and several other varieties of minerals are present. The feldspars are subangular and cloudy but the other minerals are generally well rounded.

Smith and Mertie (1930, p. 254) reported finding a "spruce log, with roots attached" on the bar of the Ikpikpuk River about lat $70^{\circ} \mathrm{N}$., more than 200 feet above sea level. Other logs were found at intervals to the mouth of the Ikpikpuk. They were "sound and unmineralized. $* * *$ shells that seemed to be of marine character and were probably also washed out of the coastal-plain deposits were noted on the bars of the Ikpikpuk ***" at about lat $70^{\circ} \mathrm{N}$.

Section in unconsolidated materials in the Ikpikpuk River valley about 2 miles south of the Valley of Willows

[Measured by E. J. Webber, Aug. 22, 1947]

Soil, dark-brown to black peaty; angular to subangular sand grains. The lower several inches becomes light gray to dirty cream and may contain lime-...--..--..

Sand, silty, brown, yellowish-red, weathering reddish brown, evenly bedded. Thin shaly exposed surface noticeably crusted and hardened. Lenses of peaty sand a few inches in extent. The yellowish-red color at the surface becomes dark orange brown 1 to $1.5 \mathrm{ft}$ from the surface. The grains are subangular to subrounded.

Sand, very fine grained, and gravel lenses. Unit is well sorted, clean, multimineral in composition. Green chert, ironstone, and quartz pebbles are rounded; most grains are subangular. Bedding even for most part, but some 3- to 6 -ft beds are crossbedded and contain coarser material, especially smooth oval granules of ironstone and black chert. The lower 4 to $5 \mathrm{ft}$ contain reworked coal grains and granules in paper-thin lenses and crossbeds. Plant and wood remains are found

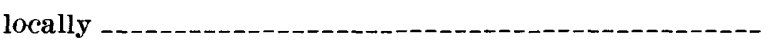

Sand and gravel mixture, poorly sorted, clean, crossbedded. Foreset beds dip as much as $24^{\circ} \mathrm{SW}$. Broken coal grains and granules are abundant. Layers and lenses of peat and plant remains are several inches thick

Sand, very fine- to medium-grained; scattered pebbles and granules _..- 1.0 Total___ 15.75
Feet 0. 75 1.5 12. 0 
Section along the Ikpikpuk River at a point about 10 miles north from the Valley of Willow's

[Measured by E. J. Webber, Aug. 24, 1947]

Soil

Sand, very fine, buff; crossbedded foreset beds dip $10^{\circ}$ to $15^{\circ} \mathrm{S}$

Silt, green, even-bedded in thin laminae

Peaty mud, evenly bedded; a very strong organic odor : sticks of wood.

Base of exposure is obscured by sand but presumably consists of blue plastic clay.

On August 25, 1947, about 16 air miles north of the Valley of Willows, Webber found a spruce tree $\log$ about 5 to 6 inches in diameter and 4 feet long in the river alluvium. On August 30, 1947, he observed a 6inch cottonwood $\log$ in the flood plain of the Ikpikpuk River, about 20 miles north of the Valley of Willows.

\section{ADMIRALTY BAY}

At the south end of Admiralty Bay as much as 15 feet of fine-grained yellow sand unconformably overlies at least 2 feet of the Skull Cliff unit. Because much of the bank was slumped during a brief visit on $\mathrm{Au}$ gust 28,1947 , details of the section are lacking. The mechanical analyses shown on figure 23 are typical of the very fine to fine-grained yellow sand. Quartz makes up about 75 percent, chert about 20 percent, plagioclase about 4 percent, and accessories about 1 percent of the material. Little weathering has occurred; some grains are stained and well rounded, and others are angular and clear. Calcium carbonate cement is more abundant at a depth of 8 feet than at 11 feet. The sands grade laterally within a few hundred feet to sandy silts (fig. 23 ), in which sorting is poorer but in which mineral assemblages are similar. Stratification throughout the exposure is slightly undulating but generally almost horizontal. Cross-stratification is not common.

Sanford and Pierce (1946, p. 10) mentioned that fragments of shallow-water marine shells occur in sands overlying the Cretaceous rocks at the Meade River coal mine.

\section{OCEAN POINT}

On July 12, 1947, E. J. Webber (1947) studied the Gubik sand in the vicinity of Ocean Point on the lower Colville River. He noted that the Upper Cretaceous rocks are overlain by 1 to 2 feet of blue clay (probably Skull Cliff unit) and that the contact is gradational. The clay is overlain, generally with distinct break, by unconsolidated sand and some gravel. In places the sand contains clay lumps a few inches above the contact. The clay in places in the uppermost part contains some sand. The pebbles and cobbles in the gravel consist of sandstone, coal, chert, and tuff. Some turritellid gastropods as well as thin- and thick-shelled pelecypods were seen in the sand and gravel immediately above the contact with the clay. The sand is even to crossbedded, with foreset beds dipping, as much as $15^{\circ}$. Windfaceted chert pebbles are rare. Bits of wood in excellent condition, one-half inch in diameter and 6 to 7 inches long, were seen locally. Several peat lenses or lumps roughly oval in shape and about 6 to 8 inches in diameter were also seen. One dark weathered zone about 6 inches thick was noticed about 20 feet above the base of the formation. The total thickness is probably about 150 feet. The entire sand section is buff colored, grading upward from gravel at the base to silt at the top. Webber considered the deposits to be marine.

MEADE RIVER

Webber (1947,p. 10) stated:

About 8 miles north of the approximate boundary between the Arctic Plateaus and the Arctic coastal plain a thickness of 55 feet of unconsolidated sediments was measured in a cut bank along the Meade River. The contact with underlying bedrock was not seen. The difference in elevation of the top of the cutbank and the top of the adjacent hill-suggests that an additional 30 feet of these beds overlies the cutbank section. East of the Meade River these deposits probably thicken, as described [above] $* * *$. The thickness of the unconsolidated deposits has been modified by erosion at many places near the southern margin of the coastal plain. Unconsolidated sand is their principal constituent. Locally, clay, silt, coaly debris, quartz, and chert pebbles, and exotic boulders of different igneous and metamorphic rocks are admixed with the sand. Beds of peat as much as 6 feet thick overlie the sands at many localities. Shells similar to those of species now living in the Arctic Ocean are found at many places in these deposits. Presumably the sediments are mostly marine.

The relationship of these sediments to the loesslike deposits to the east is not known.

\section{KIKIAKRORAK}

Stefansson, Thurrell, and Zumberge (1948, p. 4) stated:

Where seen in small exposures the Gubik sand appears to lie conformably on [Upper Cretaceous] rocks. Along the Colville River, however, in the long bluffs it is quite evident that the contact is not conformable. The contact between [Upper Cretaceous] rocks and the Gubik sand is a very low angle angular unconformity, probably not exceeding 1 to 2 degrees. In the cutbanks of the Kogohokruk [Kogosukruk] and the Kikiakrorak Rivers are found numerous evidences of stream-channelling of [Upper Cretaceous] rocks, with Gubik sand deposited in the channels. In one cutbank along the Colville River the Gubik sand was seen overlying [Upper Cretaceous] rocks in which a minor fault occurred. The relations were such as to leave no doubt that the faulting was prior to the deposition of the sand.

They also stated that exposures along the Kikiakrorak and Kogosukruk Rivers ranged in thickness from 10 to 
150 feet but that most were only 20 to 30 feet thick. These sands are included in the Meade River unit.

At lat $69^{\circ} 49^{\prime} \mathrm{N}$. and long $151^{\circ} 53^{\prime} \mathrm{W}$, along the Kikiakrorak River, Stefansson, Thurrell, and Zumberge (1948, p. 7a, station 3) described a 75-foot section of the Gubik sand:

Yellow, loosely consolidated, extremely crossbedded, with crossbedding at angles up to $30^{\circ}$. Interbeds of peat up to 4 feet thick. Basal 6 inches is conglomeratic, consisting of angular fragments and well-rounded rocks. The angular rocks in slabs up to 1 foot in diameter. The rock fragments are sandstones. volcanic ash, minor amounts of shale.

Along the same river at lat $69^{\circ} 58^{\prime} \mathrm{N}$. and long $151^{\circ} 42^{\prime}$ W., Stefansson, Thurrell, and Zumberge (1948, p. 19a, station 82) described a 25-foot section: "Yellow-buff sand, unconsolidated, with layers of gray sand. Conglomeratic sporadically for 10 feet from base. Peat interbeds." Stefansson collected no samples of the Gubik.

\section{BARROW UNIT}

The Barrow unit comprises the surface sediments to the north and to the southwest of the Meade River unit (fig. 9) with which it locally interfingers. Because of the wide area of outcrop near Barrow, it was studied more than the other units. The unit is characterized by great variability of sizes of materials, by abundant organic matter and ice, and by the variety of agents responsible for its transportation and deposition. The complexity of the unit has prohibited subdivision on an areal or stratigraphic basis. In many places beaches, bars, distributary deposits, and deltaic deposits are interspersed with shallow-water marine, lagoonal, lacustrine, and fluvial deposits. The uppermost materials seemingly have been reworked by several different agents. Subaerial reworking of any part of the marine section locally has occurred. Moreover, coastal bluffs are generally so low or slumped that good exposures are scarce. One of the best exposed and most uniform sections is along the coast southwest of Barrow. Even there complete sections are exposed for only a few days after major storms.

Ice in the upper part of the unit commonly occurs as wedges, whose growth has disturbed bedding planes in places to depths of 30 feet. Reworking by thaw lakes especially modifies initial structures and textural classifications.

Lenses range from a few inches to several feet in thickness and from a few tens of feet to many miles in areal extent. Their textures vary greatly, from claysize particles to gravel; sorting is very good to very poor. Mineral assemblages also vary greatly, especially between lenses of different textures. Almost all minerals reported in the Gubik may be found in the
Barrow unit. The percentage composition of the minerals varies widely from place to place. Erratic boulders are common at the surface near the coast (MacCarthy, 1958) and are scarce inland.

The relation of the Barrow unit to the Meade River unit is not entirely clear. Lateral gradation of the two units seems to be established, at least in part, for the Barrow unit lies conformably on the Skull Cliff unit at Christie Point, and-locally-the Meade River unit also lies conformably on the Skull Cliff unit. Locally, both units lie unconformably on the Skull Cliff unit. Whether the southwestern part of the Barrow unit is contemporaneous with the northern part is not known; greater erosion of the southwestern part suggests that it may be older.

\section{LOCALITY DESCRIPTIONS}

SKULL CLIFF

Leffingwell (1919, p. 149-150) briefly mentioned that horizontal greenish-yellow sands overlying blue-black "mud shales" crop out in a continuous bank as much as 50 feet high from Barrow to Peard Bay. No fossils were found in the shales, but locally the sands contain numerous shells, mostly of a single species. The sands are correlated here with the Barrow unit, and the lower blue-black shales with the Skull Cliff unit. Meek (1923, p. 412-414) described in more detail the Pleistocene sediments overlying Cretaceous rocks at Skull Cliff where Leffingwell collected fossils. The Pleistocene sediments are about 45 feet thick. The lower beds consist of alternate layers of friable, unconsolidated yellow sands and black fissile "mud shales"; the upper part consists of massive beds of poorly stratified yellow sand with practically no "shale." Chert pebbles are scattered throughout the upper sands. Few of the lower beds exceed 3 or 4 inches in thickness, but one "shaly" layer about 8 inches thick was noted. Meek recognized that the contact of the unconsolidated upper sediments with the Lower Cretaceous sandstone was slightly irregular and represented "some lapse in time."

To the southwest of Skull Cliff and extending into Peard Bay, Meek (1923, p. 412) differentiated black "mud shales" that grade into almost pure sands toward the top and that overlie, the "formations" at Skull Cliff. Scattered thin lenses of "conglomerate" appear in the section, the pebbles consisting for the most part of dense black chert. The surface covering is a sandy loam, about 10 feet thick, admixed with considerable vegetable material. All beds in the outcrop, according to Meek, were affected by slight upwarping. Dips do not exceed $2^{\circ}$ or $3^{\circ}$. Only the upper 25 feet of the Pleistocene section at Skull Cliff is fossiliferous, although presumably the entire unconsolidated section, according to Meek, represents only one period of deposition. 
On September 5, 1947, the writer visited the Skull Cliff area. At a point about 30 miles southwest of Barrow, 15 to 20 feet of crossbedded fine- to mediumgrained consolidated gray sandstone of Cretaceous age crops out at the base of the bank. Overlying the sandstone unconformably is 1 foot to 15 feet of the dark clayey Skull Cliff unit. Overlying the silty clay in places apparently conformably and in others disconformably is 4 to 15 feet of tan, brown, and yellow very fine to fine-grained marine sand. Clean frosted grains are common in places and appear eolian. Elsewhere clay and silt are abundant and contain pebbles and numerous marine megafossils and microfossils. In general, the silt content of the upper sand is greater toward the base but is highly variable laterally and vertically. This sand is considered to be part of the Barrow unit.

The height of the bank is irregular to the northeast and seems to vary directly as the silty clay zone of the Skull Cliff unit thickens or thins and underlying bedrock is high or low. In other places the clay is removed entirely or is cut into by ancient streams. Individual channels cut into the Skull Cliff unit are a few tens of feet to several hundred feet in width and are backfilled with sediments from the Barrow unit. Fluvial and deltaic deposits of muds, sand, and gravel appear. Lenticular crossbedded and deltaic structures are em- phasized by the contrast between clean yellow-tan sand, black organic-rich clay-silt, and other mixtures. Fragments of willows(?) are common in some lenses. The deltaic deposits are in turn overlain by tan, yellow, and brown marine sand.

WALAKPA

The coast 1.5 to 3.0 miles northeast of Walakpa (fig. 12) was visited August 21, 1950 . Unconformably overlying the Skull Cliff unit is 10 to 16 feet of marine silt, sand, and clay, which are locally crossbedded, gravelly, and highly fossiliferous. The interval is extremely variable vertically and horizontally: lenses and laminae range from pure very well sorted textural units to complex poorly sorted mixtures (fig. 24). Some of the lenses and laminae are rich in organic matter, and others are clean. These are part of the Barrow unit. Locally, fluvial deposits displace the marine sediments in channels a few feet thick and a few tens of feet wide in the upper part. The marine sediments grade into overlying beds of fluvial and lacustrine origin that are 10 to 15 feet thick (fig. 25) and contain broad, shallow ice wedges. Considerable organic matter is in distinctive pond deposits and lenses of fluvial origin, and is scattered throughout much of the sediment. These three distinct units of the Gubik

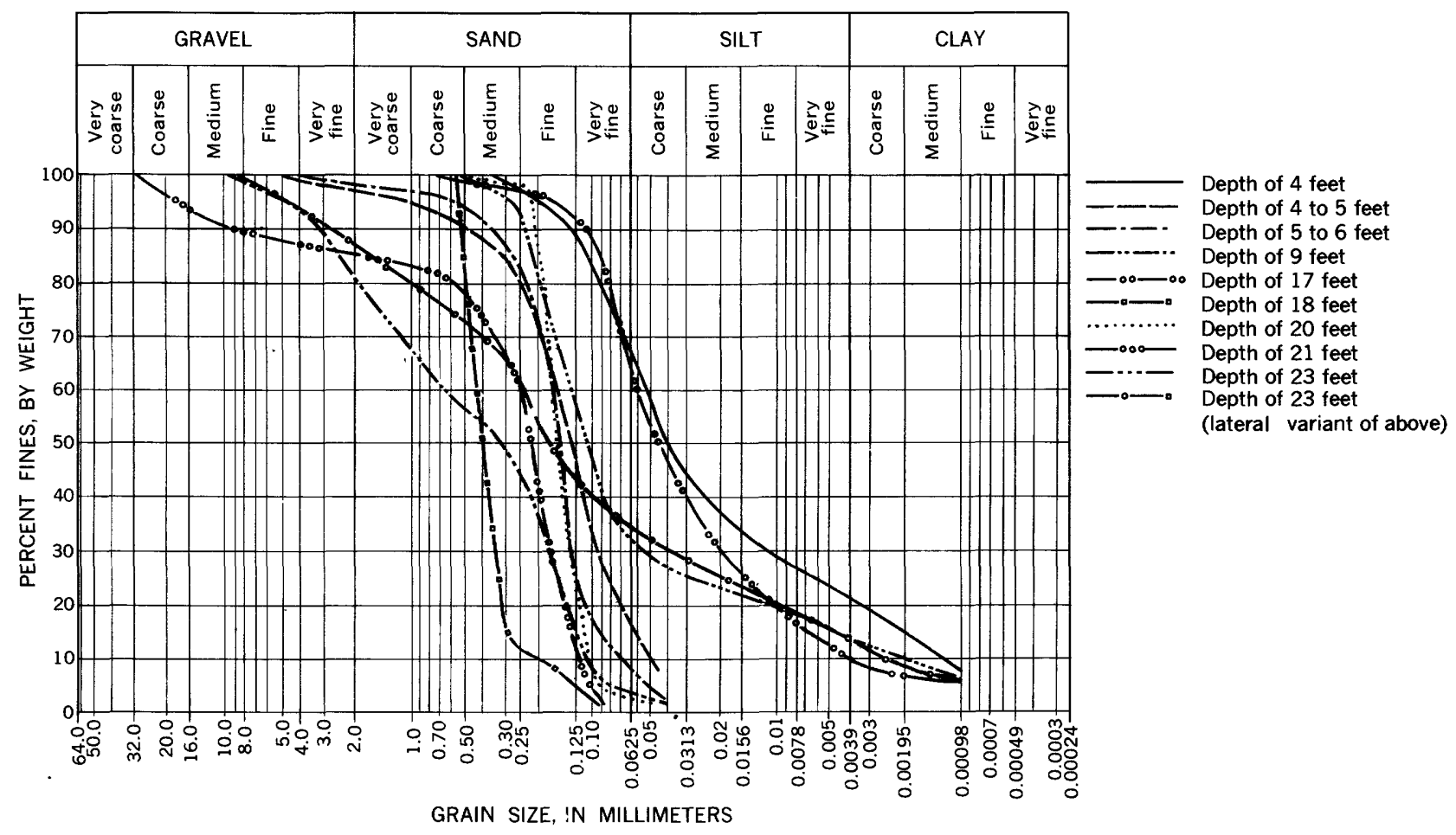

FraUnm 24.-Size-grade cumulative curves of the Barrow unit of the Gubik Formation from Walakpa. 


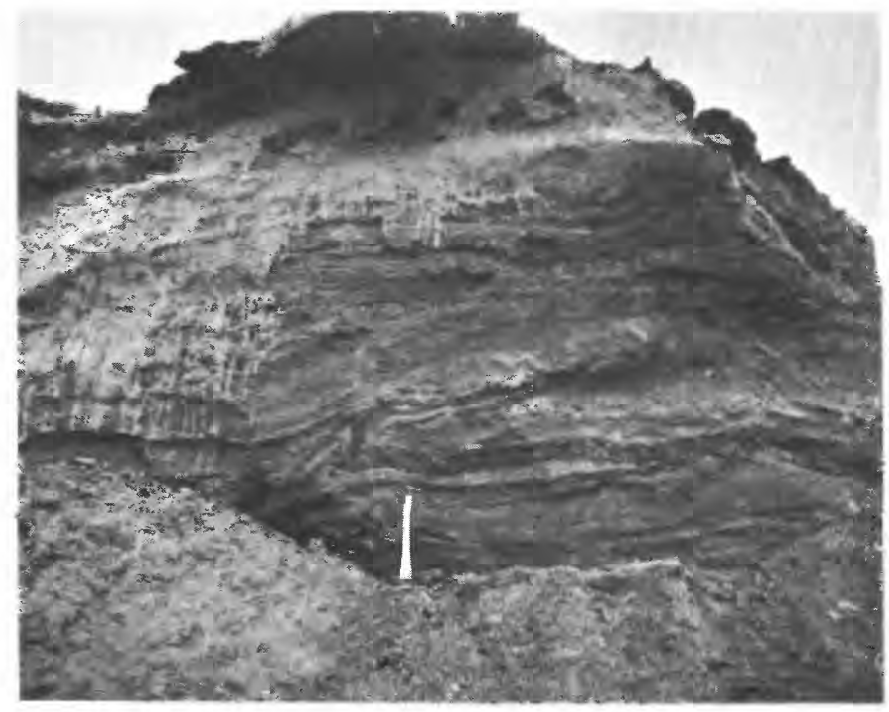

Figure 25.-Lacustrine deposits over fluvial(?) deposits in bank about 3 miles northeast of Walakpa. August 21, 1950.

Formation produce slight terraces in places where the younger units have been eroded back from bluffs more than the older units (fig. 12).

About 2 to 3 miles northeast of the aforementioned exposures the bank is only 20 feet high, and the lake sediments extend to depths as great as 12 feet. Sediments in the lower 8 feet are correlated with the Skull Cliff unit (fig. 15). Fluvial silt, sand, and gravel are common in channels cut into the top of the marine sediments. Iron staining of sediments under the lakes extends to depths of 6 feet. To the northeast gravel becomes a prominent part of the marine deposits. $\mathrm{Nu}$ merous irregular structures are interpreted as fossil ice wedges, ice-shove features, and primary deposition around ice blocks in former beaches or bars. The age of the lake is not known, but the sediment in the upper 12 feet is considered to be part of the Barrow unit.

\section{NUNAVAK}

On August 10, 1946, the writer collected samples from the Barrow unit at Nunavak, 5.5 miles southwest of Barrow. The top of the bluff is 20 to 25 feet above sea level. The upper 8 to 13 feet of the bluff is composed of clayey silt horizontally interbedded with clean sand in thin laminae and lenses as much as a few inches in thickness (fig. 26). These beds of the Barrow unit are conformable on the Skull Cliff unit. The upper sands are bluff, yellow, cream, and brown; the silts are yellowish brown to brown. One sample from a point about 7 feet beneath the surface and 18 feet above sea level was composed dominantly of rounded to angular

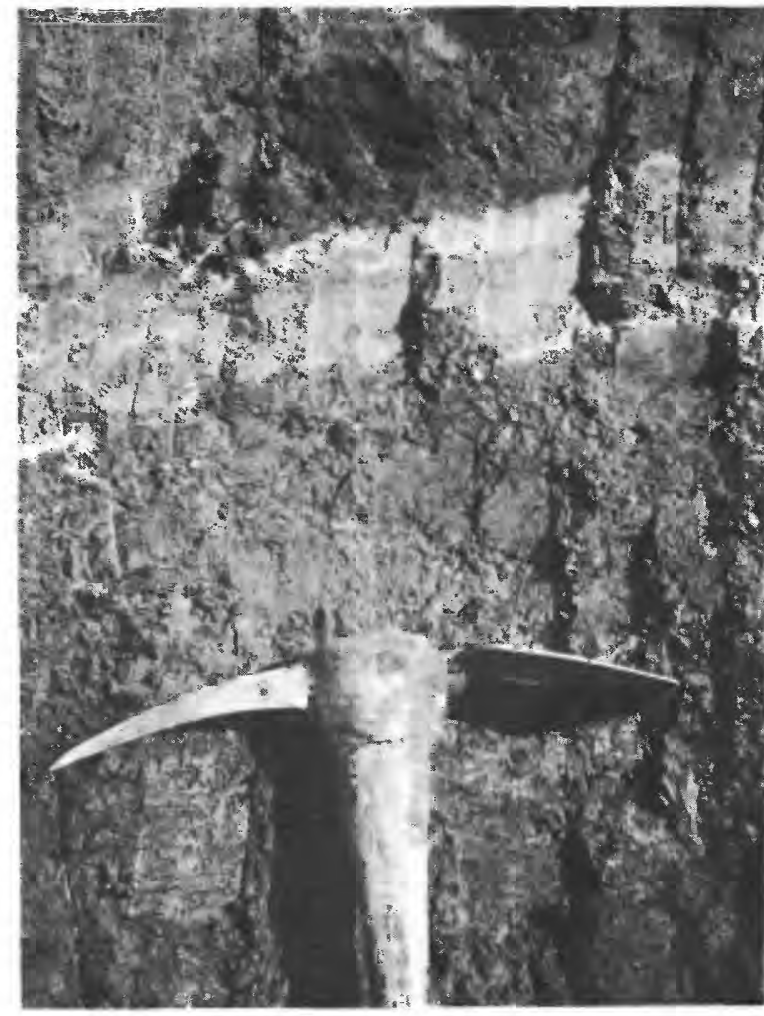

Frgure 26.-Part of the Barrow unit of the Gubik Formation at Nunavak, showing gray blocky sandy silty clay at base, a thin lens of clean yellow sand in the center, and yellowbrown blocky clayey silty sand at top. August 10, 1946.

quartz. Sand and silt sizes predominate (fig. 27), and the mean particle size is $0.063 \mathrm{~mm}$; clay and pebbles are present, and the sorting coefficient is 4.1. Organic content is 0.3 percent; carbonate reaction to $\mathrm{HCl}$ is strong. Most quartz grains are iron stained and coated with clay and carbonates. Ilmenite is common; sphene, muscovite, and chlorite were seen. Fragments of foraminiferal(?) tests are common.

CHRISTIE POINT

During August 18-20, 1946, samples of the Barrow unit were obtained at depths of 4 and 5 feet in the lagoonal bank about 2 miles northwest of Christie Point and 25 miles southeast of the Barrow airbase. These samples were taken below the peaty silt fillings in surface polygon ponds that extended as much as 4 feet below the surface. The bank, locally called Katchicksuk Bluff, rises a maximum of 20 feet above sea level and exposes an irregular thickness of yellow-brown sandy clayey silt (fig. 27) over greenish-brown sandy clayey silt (fig. 27), which in turn is underlain by 11 feet of gray sandy clayey silt of the Skull Cliff unit. 
The exposed beds resemble those at Nunavak. Only the upper 9 feet of the section is considered to be part of the Barrow unit. Horizontal bedding is vaguely distinguishable in a few places; most beds are cut and highly contorted by ice wedges.

The mean particle size of the two upper beds is 0.061 and 0.037 ; sorting coefficients are 2.3 and 5.8. The largest grain size in each is 3 and $2 \mathrm{~mm}$ in diameter, respectively. The silt and sand fractions are composed dominantly of angular to well-rounded grains of quartz and chert. Most are coated with clay and carbonate stained with iron. Chlorite is present. Fresh angular andesine was recognized in the greenish-brown zone 5 feet below the surface. Ilmenite was common to both beds. Colorless transparent hexagons of kaolinite(?) and illite(?) are increasingly common downward. Scattered pebbles of chert, quartzite, and other rocks were seen in the upper beds. Organic content increased downward from 0.4 to 1.4 percent. Minute shell fragments were seen in each sample; Foraminifera of unknown species were recognized in the lower sample.

The yellow-brown and greenish-brown silts interfinger complexly; the upper yellow-brown silt is considered to be the oxidized phase of the greenish-brown silt. The greenish-brown silt conformably overlies the gray silt, and in places the contact is irregularly gradational over several inches.

\section{BARROW}

On September 3, 1946, and again on July 24, 1950, samples of the Barrow unit were collected from the ice cellar at the naval airbase at Barrow. The cellar is in an area of high-centered polygons, about 750 feet from the ocean and directly southeast of the camp. A shaft was sunk in the center of a polygon about 30 feet in diameter. The shaft was open for inspection only briefly during initial construction of the cellar, which during 1946 extended to a depth of 22 feet from the surface. During 1950 the cellar was enlarged laterally and extended to a maximum depth of 33 feet.

The following section was revealed :

Section exposed in 1946 in ice cellar, naval airbase, Barrow

Thickness (feet)

Vegetation and sandy clayey silt, light-tan or brown on top to dark-brown at base-the top of permafrost.----

Peat and silt. The peat is in a lens striking $N$. $75^{\circ} \mathrm{E}$. and dipping $70^{\circ} \mathrm{S}$. Shreds and stringers of peat 1 to 6 in thick and 1 in to $4 \mathrm{ft}$ in length parallel the lens. The upper $1 \mathrm{ft}$ of the peat contains considerable gray sandy silt that grades over a vertical height of 1 to 3 in into the dark-brown sandy clayey silt

Silt-clay, gray and sand with pebbles (fig. 28) and much granular ice. One ice wedge was $6 \mathrm{ft}$ in height and 6 inches in width. Noncalcareous. Organic matter is 3.8 percent in one sample near the top (at a depth of 6 $\mathrm{ft}$ ) the bulk of the sand is well rounded to angular quartz and chert of several generations, coated with organic material ; median size is $0.097 \mathrm{~mm}$ and the sorting coefficient is 4.0. The pebbles are dominantly wellrounded and polished chert as much as one-half inch in diameter. Clean tan sand in zones a few inches in dimension are intercalated at the base

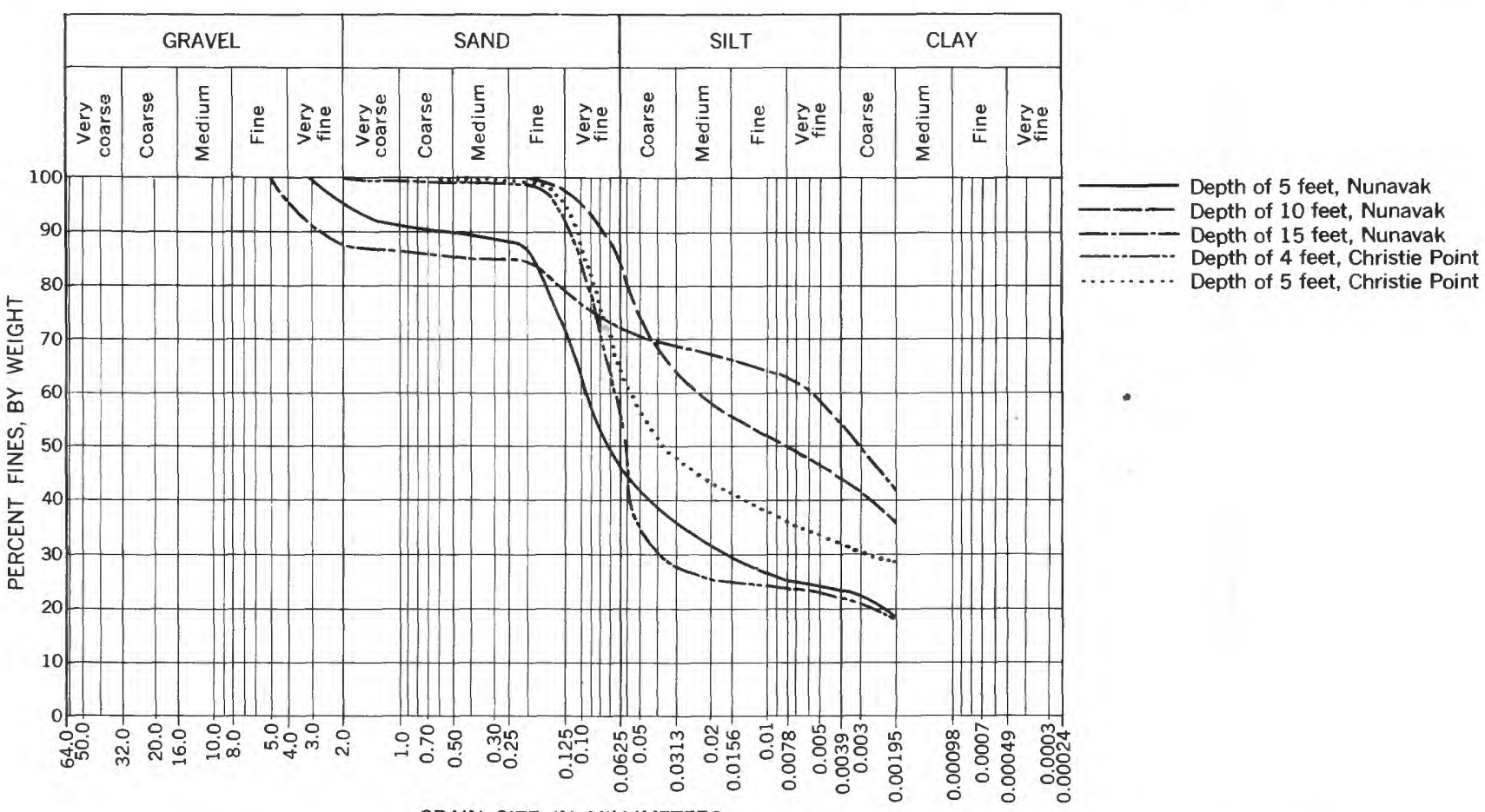

GRAIN SIZE, IN MILLIMETERS

Frgure 27.-Size-grade cumulative curves of the Barrow unit of the Gubik Formation from Nunavak and Christle Point. 
Section exposed in 1946 in ice cellar, naval airbase, BarrowContinued

Thickness (feet)

Sand, clean, tan; irregular bedding: layers of gravel a fraction of an inch to a few inches thick and zones of gray sand are interbedded irregularly. The gravel is largely iron stained; some sand is also irregularly stained. Bedding is virtually horizontal in the tan sand and very poorly defined, whereas the gravel layers and iron-stained zones show well-defined undulating to contorted bedding. One sample of fine to very fine clean tan sand collected at a depth of $9 \mathrm{ft}$ is largely quartz and chert, but muscovite, tourmaline, vesuvianite(?), apatite, microcline, andesine, ilmenite, magnetite, chlorite, sphene, hornblende, topaz, tremolite (?), epidote, zircon, garnet, and other unidentified minerals were seen. Grains are well rounded to angular; the quartz and chert are of several generations or kinds. Pebbles consisting mostly of chert and less commonly of quartzite and granitic rock as much as one-fourth inch in diameter are scattered throughout. Foraminiferal shells and fragments of larger shells are scattered throughout. Another sample also collected at a depth of $9 \mathrm{ft}$ but in a different part of the shaft consists of iron-stained sand and gravel. It is composed dominantly of quartz and chert of several generations as in the aforementioned sample; partly altered andesine and some chlorite and other minerals were seen, but the variety in mineral composition is not as great as in the previously mentioned sample. The gravel is well rounded; the sand is angular to well rounded. A similar sample of the iron-stained sand and gravel from a depth of $15 \mathrm{ft}$ contained more fragments of marine megafossils. Neptunea and Macoma are present
Section exposed in 1946 in ice cellar, naval airbase, BarrowContinued

Sand, tan, to gray, generally very fine to fine-grained. Acute-angle crossbedding in the lower part; many thin layers of oil-stained sand and scattered pebbles in the upper $2 \mathrm{ft}$; undulating bedding in lower part contrasts with the generally contorted bedding in upper part. One sample of the tan sand at a depth of $18 \mathrm{ft}$ and one sample of the oil-stained sand and scattered pebbles at the same depth are similar texturally to those above. One sample at $19 \mathrm{ft}$ also contains glaucophane, albite, rutile, and other unidentified minerals in addition to those listed previously. Similar material extends to the bottom of the ice cellar at $22 \mathrm{ft}$ (fig. 28). In the lowermost sample the median size is $0.13 \mathrm{~mm}$ and the sorting coefficient is 1.3

The top of the section exposed in 1950 was at a depth of 23 feet, directly below the above section. It is as follows :

Thickness (feet)

Sand, horizontally bedded, gray to tan and brown, mottled, clean, very fine to medium-grained; scattered pebbles and shell fragments. Organic-rich layers $1 / 4$ to $1 / 2$ inch apart and $1 / 16$ to $1 / 8$ inch thick are abundant throughout. Shells are particularly abundant in the lower part, which shows slight unconformity with the underlying gray to tan sands without organic layers--

Sand, tan to gray, uniformly fine; little or no organic layers, shell fragments, or pebbles_-_.--_-_-_-_-_-

Sand, bedded, fine; organic-rich layers scattered irregularly throughout

Sand, gray, silty, and gravel pebbles as large as 2 inches in diameter; numerous shells and much organic matter in thin lenses.

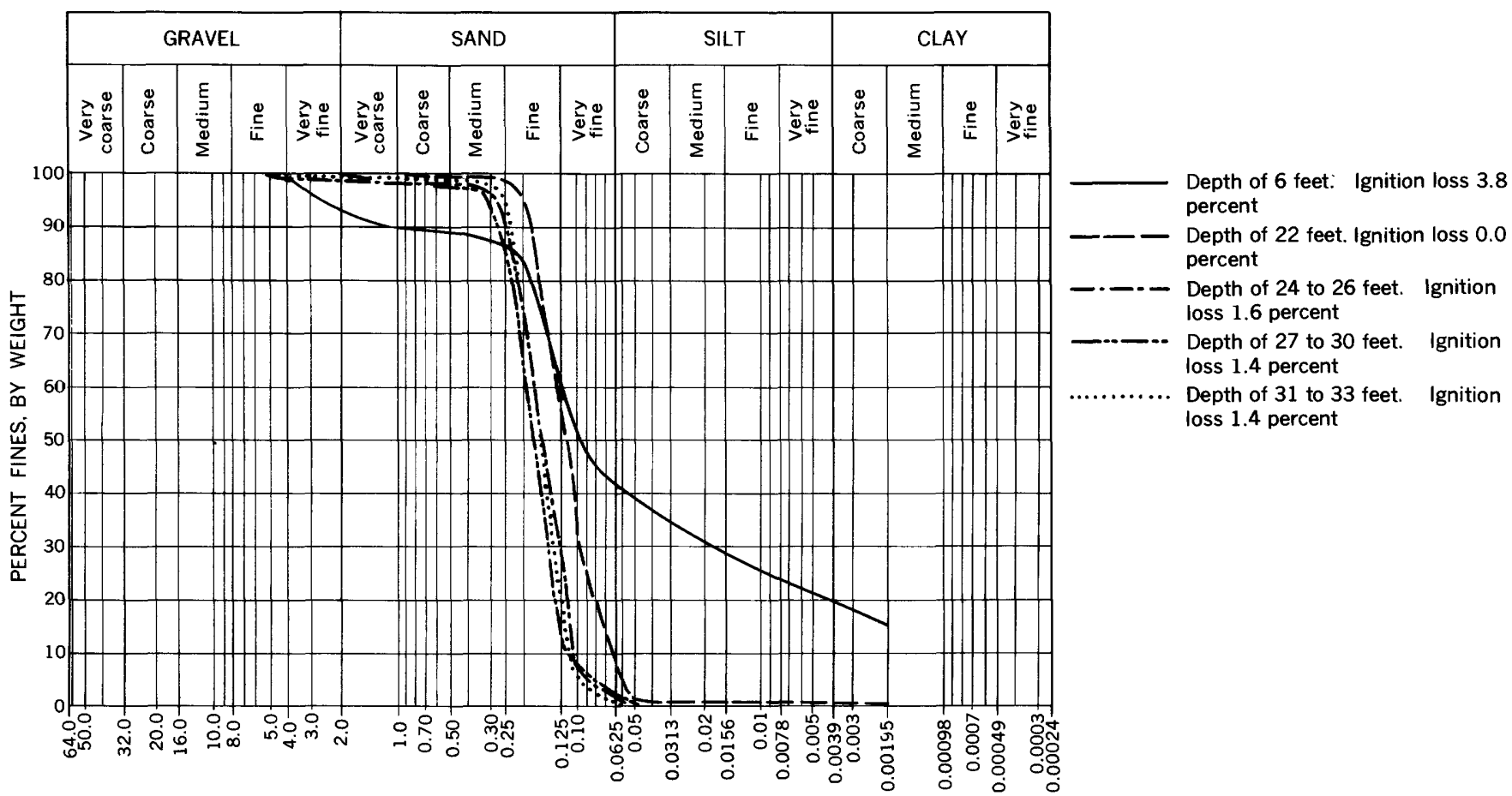

GRAIN SIZE, IN MILLIMETERS

Figdri 28.-Size-grade cumulative curves of the Barrow unit of the Gubik Formation, Barrow area, from airbase ice cellar. 
Eleven samples were taken from the lower part of the aforementioned section. Mineralogically and texturally the samples resembled the gray to tan sand overlying them. One channel sample from 24 to 26 feet is shown by the cumulative curve (fig. 28); the median size is $0.16 \mathrm{~mm}$ and the sorting coefficient is 1.3. Another sample from 27 to 30 feet is represented on figure 28 ; the median size is $0.18 \mathrm{~mm}$ and the sorting coefficient is 1.3. One sample from 28 feet and one from 29.5 feet are similar; median sizes are $0.12 \mathrm{~mm}$ and $0.16 \mathrm{~mm}$, and sorting coefficients are 1.3. A channel sample from a depth of 31 to 33 feet is represented on figure 28 ; its median size is $0.17 \mathrm{~mm}$ and sorting coefficient is 1.2.

One sample of an organic-rich lens of fine- to very fine grained sand, coal fragments, and chert pebbles as much as half an inch in diameter is very rich in foraminifer, ostracode, and mollusk fragments. Pleistocene foraminifers of the genera Cribroelphidium and Elphidiella are present; numerous specimens of Recent species were seen. Coal fragments make up about 10 percent of the total. All sand grains are coated with organic material.

The uppermost 9 feet of the section presumably represents lagoonal deposition and later lacustrine modification. Calcium is leached to at least 6 feet, as shown by tests with $\mathrm{HCl}$. A zone of interfingering marine and lagoonal deposits extends downward a few feet to a depth perhaps of about 15 feet. The lower beds are entirely marine. The material is virtually the same from the base of the section to the depth to which lacustrine modification was effective-about 6 feet or as much as 8 feet. Shallow-water marine crossbedding and contorted bedding resulting from ice shoving(?) are representative of about half of the section; these structures alternate with horizontal or slightly undulating beds. Sorting is generally very good except for pebble-rich layers, but pebbles are scattered throughout. Lenses of organic-rich sand, gravel beds, and fossil-rich zones are presumably the result of slight irregularities in the sea floor, but Foraminifera and mollusk fragments are scattered throughout. The dominant mineral is quartz. Grains range from well rounded, stained, and frosted to fresh and angular; euhedral crystals, some of which are doubly terminated, also occur. Typical grains are clear and colorless, pink, red, brown, and black. Rutile, liquid, and other inclusions are common in some grains. Obviously, many sources and many generations are represented. Chert or flint is the next most abundant mineral. It is typically white, cream, tan, brown, green, and black and is commonly translucent to opaque. Most grains are well rounded and polished; the darker flinty varieties commonly have percussion marks on the surface.
They are finely crystalline or fibrous. Carbon(?) is the most abundant inclusion in the siliceous minerals, but iron oxides( ?), manganese(?), fresh pyrite cubes, and other materials are common. The other minerals mentioned previously are largely missing in the upper part that was subjected to longer weathering or are reduced in numbers and show considerable alteration. In the cleaner parts of the lower beds most grains are fresh; many are angular, although rounding is characteristic. Texturally these beds resemble parts of the Meade River unit but are referred to the Barrow unit.

In the summer of 1950 several special holes were drilled near the naval airbase at Barrow (fig. 9) by Arctic Contractors for the Arctic Research Laboratory permafrost investigations. Partial cores were obtained from holes 1, 2, and 7 and were examined by Florence Rucker Collins, U.S. Geological Survey in Fairbanks. By the use of compressed air as the drilling fluid, cores were obtained in a frozen state from another special hole, called Camp Hole 3. The cores were shipped to Fairbanks and examined by Florence Rucker Collins while still frozen. The cores represent intervals between 10 and 71 feet and 104 and 109 feet. She described the cores as follows (written communication, March 21, 1951):

All the cores received are of Gubik sediments, probably of Pleistocene age. The sands [fig. 29] are distinctive, unusually well rounded, and typically contain a large amount of yellow and orange quartz, and yellow and black chert grains. Most of the grain surfaces are exceptionally well polished; some are pitted, and a few frosted. Other sediments present often show very poor sorting, with grain size ranging from pebbles larger than $1 \mathrm{~cm}$ in diameter to clay. Sieve analyses of the poorly sorted material usually have two maximums, and in one case three well-defined maximums (coarse sand and pebbles, very fine sand, and clay, in the sample 11-16 feet, hole 2) are present. The cleaner sands are sparsely fossiliferous; the "pebbly clay" contains a moderate number of ostracods and Foraminifera, while the interlaminated silty sand and silt at 34 feet in hole 2 had abundant calcareous Foraminifera and many ostracods. The Foraminifera are indicative of a marine environment; the ostracods, according to F. H. Swain, 1949, are types found in cold marine neritic environment of moderate depth, having "living relatives in the north Atlantic and Arctic Oceans, in water generally more than 10 fathoms and less than 100 fathoms deep."

Recovery of cores was too poor to permit correlation except between two holes, Nos. 2 and 7, about 1,500 feet apart. (See fig. 11.) Between a depth of 10 ana 50 feet, the two holes apparently penetrated the same sequence of beds at about the same depths. A thin but distinctive pebbly clay bed occurs between 25 and 30 feet in both holes; brown laminae in sands immediately above and below the clay beds are present in both. Medium-grained gray clay occurs in the bottom of both holes at a depth of about 100 feet. Detailed logs follow. 


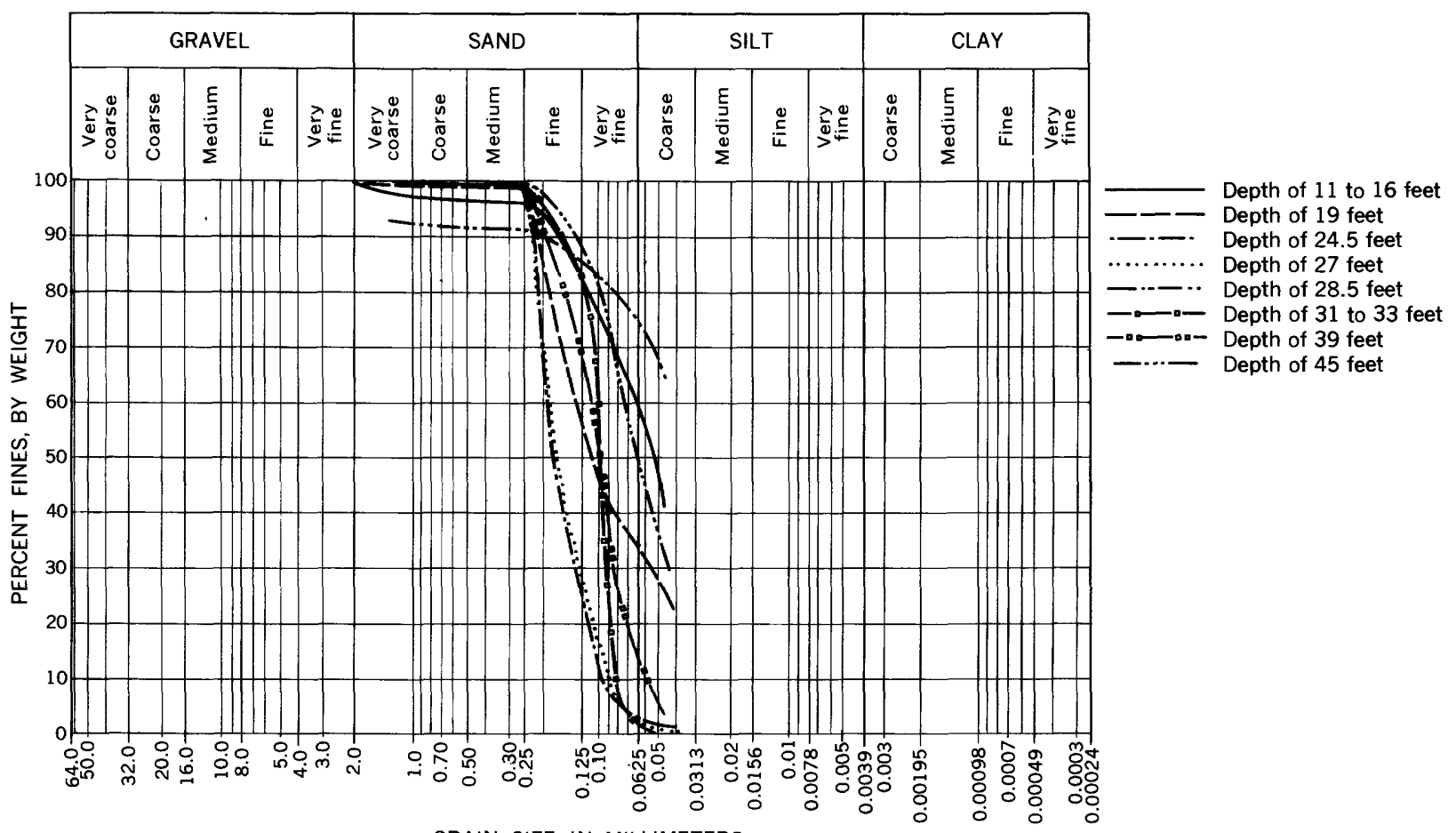

GRAIN SIZE, IN MILLIMETERS

Figurn 29. - Size-grade cumulative curves of the Barrow unit of the Gubik Formation from Barrow area drill cores.

Arctic Contractors hole 2, Barrow, Alaska

[A continuous series of cores from 11 to $52 \mathrm{ft}$ with a total recovery of $26 \mathrm{ft} 9$ in and a 38-in section of core from 96 to $101 \mathrm{ft}$ were sent to the laboratory]

\begin{tabular}{|c|c|c|}
\hline $\begin{array}{l}\text { Depth } \\
\text { (feet) }\end{array}$ & $\begin{array}{c}\text { Amount } \\
\text { recovered } \\
\text { Ft in }\end{array}$ & Description \\
\hline $11-16$ & 1 & $\begin{array}{l}\text { Clay, silty, very sandy, grayish-yellow (silt } \\
\text { and clay fraction is yellow; washed sand } \\
\text { is yellowish gray). The sediment lacks } \\
\text { any evidence of bedding or other struc- } \\
\text { tures possibly because of collapse of the } \\
\text { material after melting of the permafrost. } \\
\text { Scattered well-rounded gray, brown, or } \\
\text { black chert grains and pebbles (1 to } 5 \text { mm } \\
\text { in diameter) are scattered throughout. } \\
\text { The sieve analysis (fig. 29) has } 3 \text { maxi- } \\
\text { mums and demonstrates poor sorting; } \\
\text { carbonate content at the same depth is } \\
\text { 8.06 percent. The sand grains are well } \\
\text { rounded to subangular and consist largely of } \\
\text { clear quartz, but 10 to } 15 \text { percent consists } \\
\text { of white, yellow, and orange quartz and } \\
\text { orange and black chert. Scattered frosted } \\
\text { grains are present, and pitted grains are } \\
\text { common. A few clear quartz grains are } \\
\text { angular, having sharp edges and low } \\
\text { sphericity; one euhedral unworn bipyram- } \\
\text { idal quartz crystal was seen. Mica and } \\
\text { pyrite are absent, but there are sparse } \\
\text { grains of other minerals and rock frag- } \\
\text { ments. All the grains have fresh and } \\
\text { some have polished surfaces, except for } \\
\text { the pitted or frosted ones mentioned } \\
\text { above. Fragments of pelecypods and } \\
\text { ostracodes are present; two specimens of } \\
\text { a calcareous foraminifer (Eponides sp.) } \\
\text { were found. }\end{array}$ \\
\hline
\end{tabular}

Arctic Contractors hole 2 , Barrow, Alaska-Continued

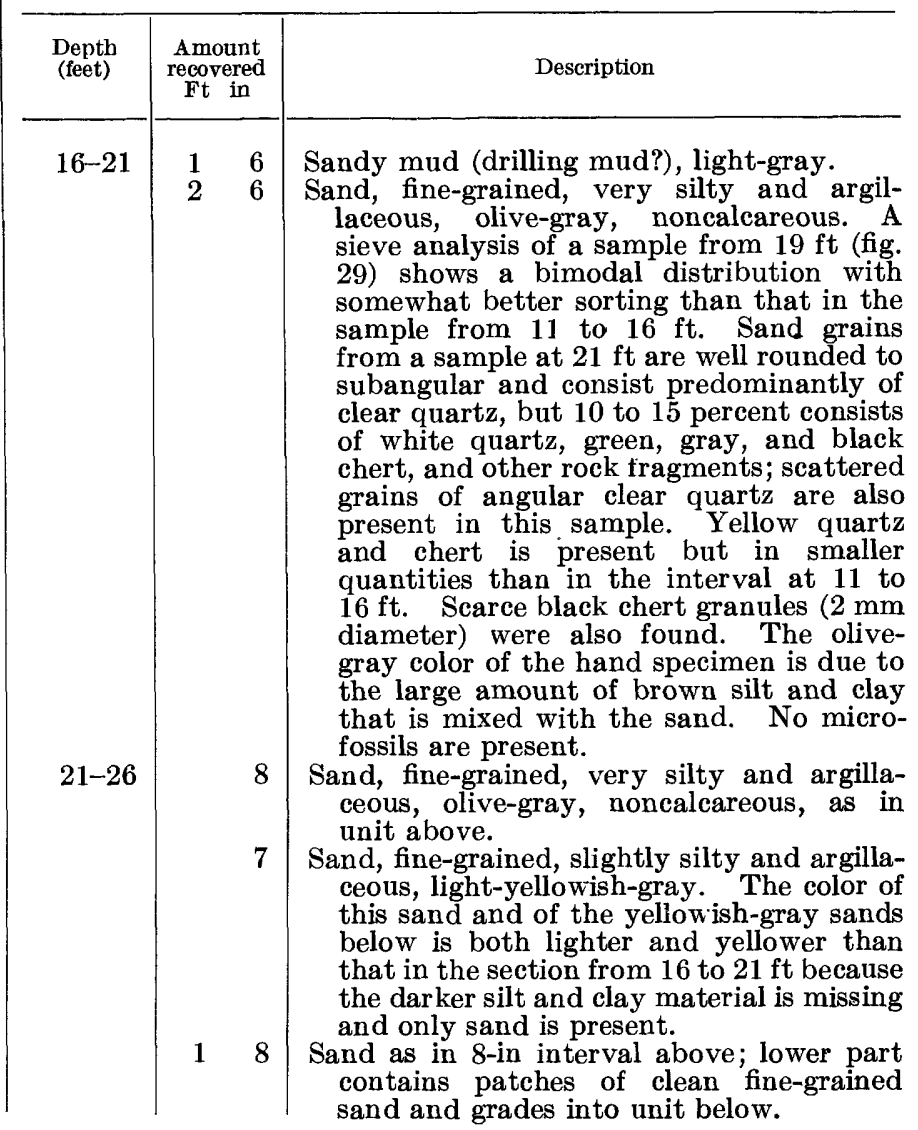


Arctic Contractors hole 2, Barrow, Alaska-Continued

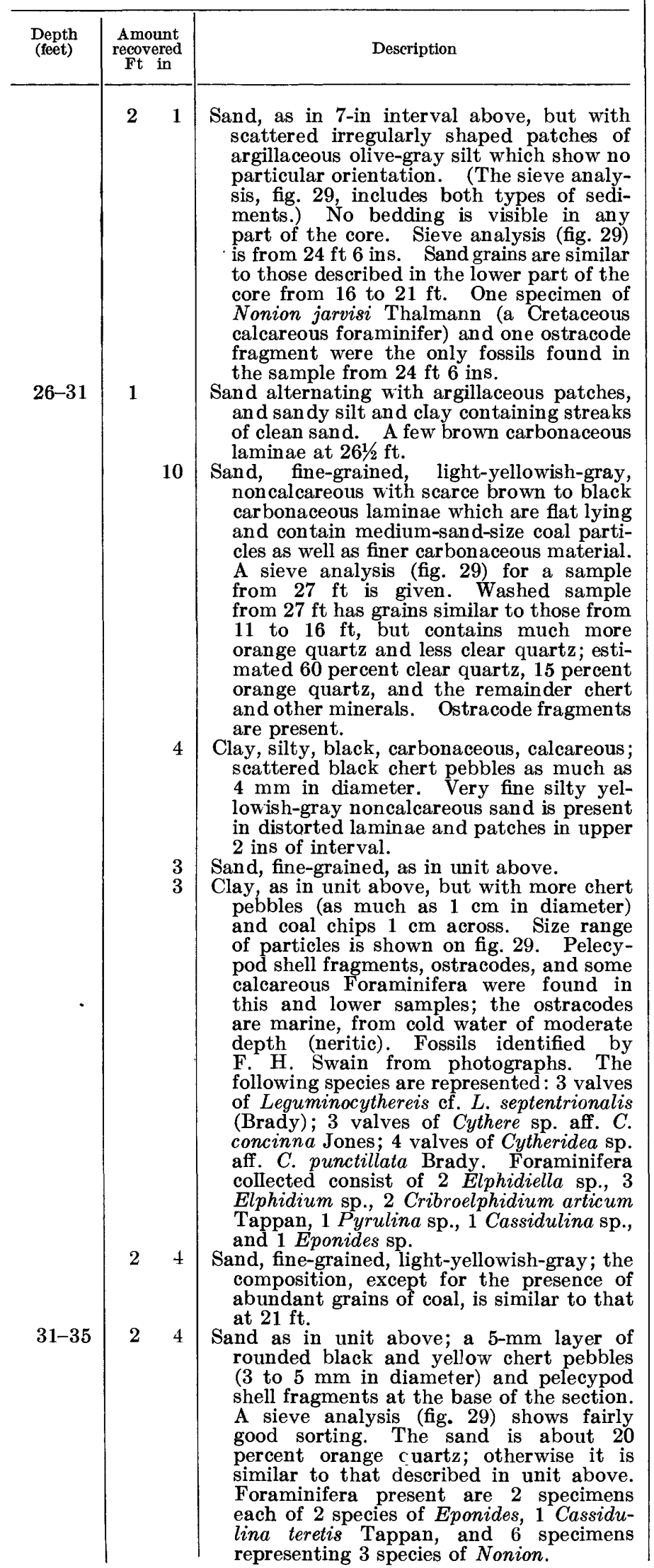

Arctic Contractors hole 2 , Barrow, Alaska-Continued

\begin{tabular}{|c|c|c|}
\hline $\begin{array}{l}\text { Depth } \\
\text { (feet) }\end{array}$ & $\begin{array}{c}\text { Amount } \\
\text { recovered } \\
\text { Ft in }\end{array}$ & Description \\
\hline & 18 & $\begin{array}{l}\text { Interlaminated olive-gray silt, slightly cal- } \\
\text { careous, and light-olive-gray very fine } \\
\text { sand, both very argillaceous and at places } \\
\left.\text { slightly crossbedded (dips } 0^{\circ} \text { to } 5^{\circ}\right) \\
\text { Scarce laminae of fine grained sand. At } \\
\text { the top of the section and from } 34^{1 / 2} \text { to } 35 \mathrm{ft} \\
\text { are scattered brown carbonaceous laminae, } \\
\text { which coarsen and thicken with depth. } \\
\text { Foraminifera are abundant in the sample } \\
\text { from } 34 \mathrm{ft} \text {, and Ostracoda more numerous } \\
\text { than in other samples. }\end{array}$ \\
\hline
\end{tabular}

Ostracodes: 13 valves of Cythere sp. aff. $C$. concinna Jones, 10 of which are immature; 1 valve of $C$. cf. C. pulchella Brady; 3 valves of $C$. sp. aff. C. cicatricosa Reuss; 2 valves of Cytheridea sp. aff. C. punctillata Brady; 1 unidentifiable small ridged valve. Numerous ostracode fragments unidentified.

Foraminifera: Nonion jarvisi Thalmann is abundant, with nearly 50 specimens; several related species total over 100 specimens. Elphidium is also abundant, with 4 species and approximately 75 specimens. Cribroelphidium articum Tappan is common, with some 20 specimens. Eponides is represented by some 25 specimens of 4 species and Anomalina by about 15 specimens of a single species. Cassidulina teretis Tappan and C. sp. have 5 specimens each; and there are 3 specimens of Pyrulina sp. and 3 of Pullenia sp.

35-41 36 Sand, fine-grained, light-yellowish-gray; laminae of yellowish-gray fine-grained very silty and argillaceous sand and scarce thin beds of olive-gray clay. The sieve analysis shown on figure 29 is for a sample taken at $39 \mathrm{ft}$; carbonate content at the same depth is 3.98 percent.

Ostracodes present are 1 valve of Haplocytheridea cf. $H$. sorbyana (Jones) and 1 valve of Cythere sp. aff. C. concinna Jones. Foraminifera are Nonion jarvisi Thalmann, and 3 specimens representing 2 species of Elphidium.

42-52 $3 \quad 6 \quad$ Sandstone, very fine grained, very silty and argillaceous, light-olive-gray, calcareous; slightly darker and carbonaceous toward the bottom. A cobble larger than the diameter of the core and composed of quartzitic sandstone, which is very light yellowish gray and very slightly calcareous, occurs 2 ins above the base of the core. A sieve analysis for a sample taken at a depth of $45 \mathrm{ft}$ is given on figure 29; carbonate content at the same depth is 28.9 percent.

Foraminifera are as follows 1 Eponides sp. 1 Cassidulina sp., 1 Nonion sp., and 1 valve of Haplocytheridea cf. $H$. sorbyana Jones.

96-101 32 Clay shale-medium-light-gray; patches of yellow iron stain in the upper few inches and at the base. The shale is soft and noncalcareous, and contains abundant. coarse to very fine grained sand and silt similar to that in the sands described in the unit above. Fracture is irregular to hackly, and no bedding is visible. Foraminifera were more common in this sample than in any other sample except that from $34 \mathrm{ft}$; the following types are represented: 1 Quinqueloculina; 1 large 
Arctic Contractors hole 2, Barrow, Alaska-Continued

\begin{tabular}{l|l|l}
\hline $\begin{array}{c}\text { Depth } \\
\text { (feet) }\end{array}$ & $\begin{array}{c}\text { Amount } \\
\text { recovered } \\
\mathrm{Ft} \text { in }\end{array}$ & Description \\
\hline & $\begin{array}{l}\text { Elphidium and 5 smaller ones represent- } \\
\text { ing 2 other species; 1 specimen each of } \\
\text { two species of Pyrulina; 4 specimens of } \\
\text { Nonion sp., 1 Nonion jarvisi Thalmann, } \\
\text { and 1 specimen of a different species of } \\
\text { Nonion; and 2 Cassidulina teretis Tappan. }\end{array}$ \\
\hline
\end{tabular}

Arctic Contractors hole \%, Barrow, Alaska

[Cores from 12 to $52 \mathrm{ft}$ and from 104 to $109 \mathrm{ft}$ with a total recovery of $36 \mathrm{ft} 6$ in were sent to the laboratory. Because the sediments are similar to those in hole 2 , neither sieve analyses nor carbonate content tests were made on these cores, and only one sample (from 12 ft) was examined for microfossils]

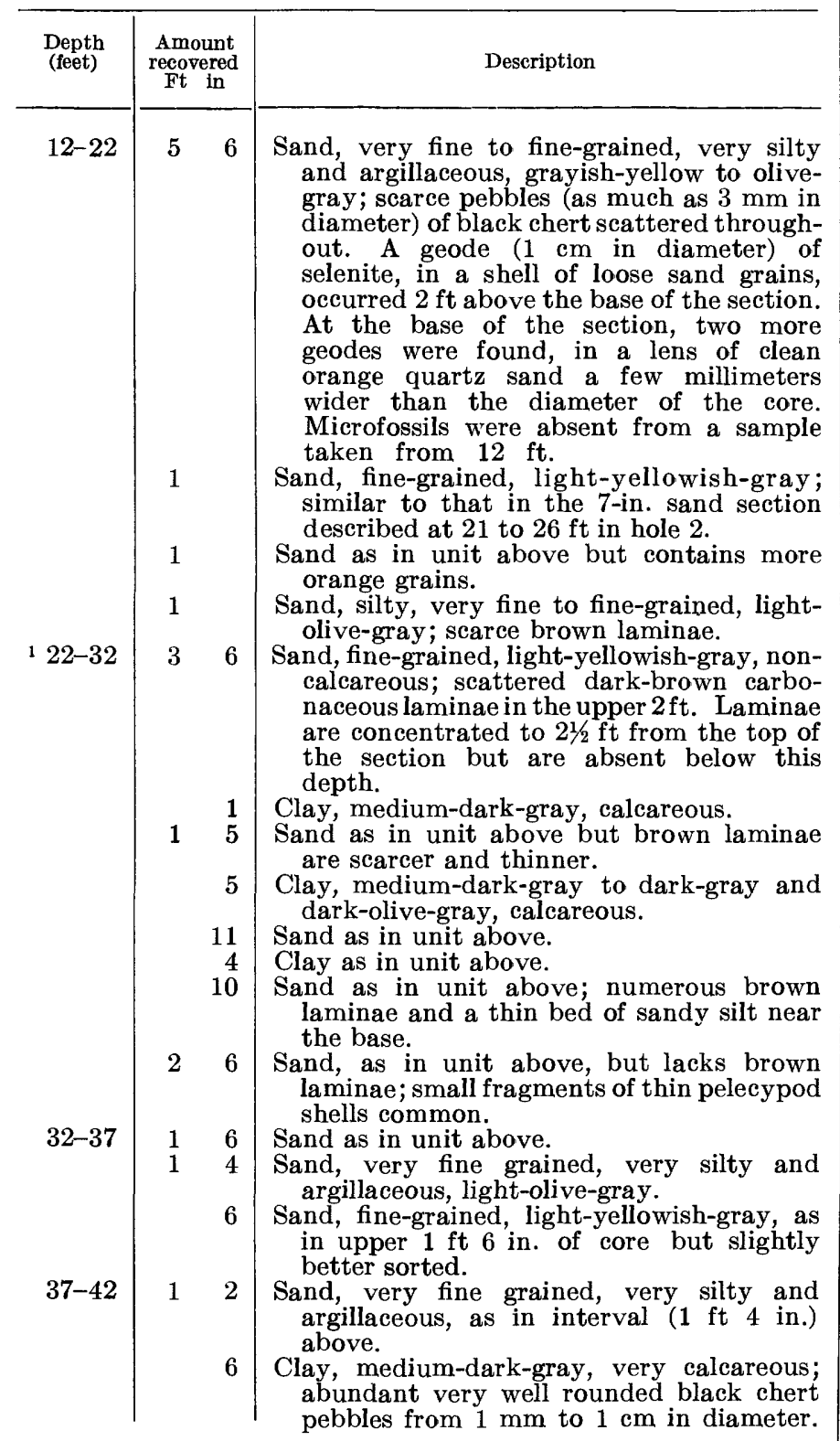

1 Section from 26 to $30.8 \mathrm{ft}$ was mixed before arrival at the Fairbanks laboratory (letter to T. G. Roberts from G. R. MacCarthy, Aug 23, 1950). The core as a whole is very similar to that taken from 27 to $31 \mathrm{ft}$ in hole 2 .
Arctic Contractors hole 7, Barrow, Alaska-Continued

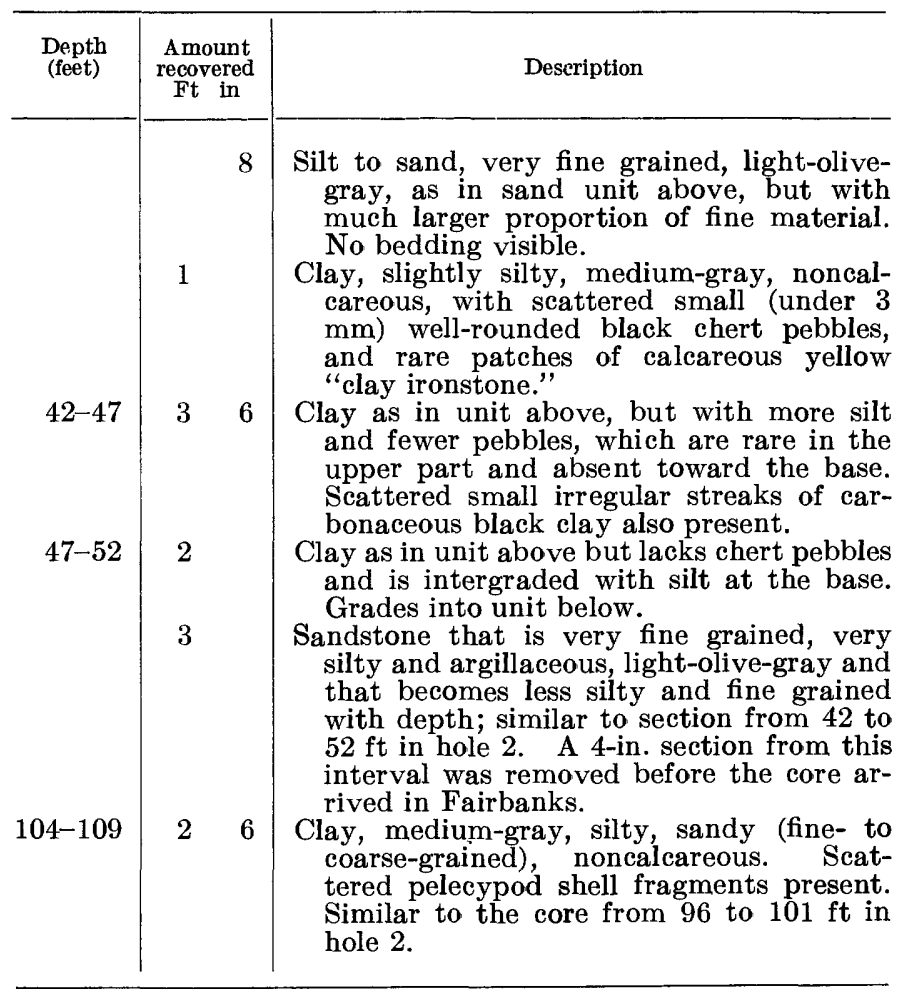

Emerged bars and beaches are relatively common features of the Arctic coastal plain province. Some of these features that include lagoonal, lacustrine, and fluvial deposits are part of the Barrow unit. One of the most accessible bars is about 1 mile east of the naval airbase; it rises a maximum of 25 feet above sea level and may be traced more than 4 miles in an arcuate course surrounding a recently drained salt-water lake or lagoon. The material composing the emerged bar ranges from clay to gravel in lenses of various sizes and attitudes. These lenses range from a fraction of an inch to several inches in thickness and several feet to several tens of feet in areal extent. Sections a few feet apart are dissimilar. Figure 30 shows a typical section made on August 7, 1947, by bulldozer supervised by the writer. The section was cut through one of the narrowest and coarsest parts of the bar. Initial structures are undisturbed below the active layer, except at ice wedges, but were cut into on each side by waves and currents of lagoons or lakes that formerly occupied either side of the bar. Quartz and chert are the dominant minerals. Most grains are well rounded, polished, and worn, but fresh angular fragments are common. Except for local turf, the uplifted bars resemble the present beaches. Below the active layer, primary deposition structures commonly are retained unmodified. 
TESHEKPUK

The north side of Teshekpuk Lake is cut 20 to 30 feet into yellow, tan, and brown silt and sand containing considerable clay locally and scattered pebbles and marine shell fragments. These sediments are con. sidered to be part of the Barrow unit, although some beds texturally resemble the Meade River unit. On August 29, 1947, a brief visit was made to the head of the small embayment east of the prominent point on the north side of the lake. At one point the section is 0 to 2 feet of peaty silt under vegetation, 10 to 15 feet of darktan to brown silty sand and sandy silt, and 8 feet of banded very fine grained yellow sand and silty gray clay. Stratification planes are undulating but continuous for at least 100 feet. One poplar(?) $\log 3$ inches in diameter was embedded in clayey sandy silt 1 foot above lake level. Fragments of plant tissue are common. Samples in a 25 -foot bank were collected at depths of 10, 17, and 24 feet (fig. 31). Slumping and caving of the bank was rapid, and doubtless the position of each sample is only relative, as some movement of the face is expected. The lower sample of gray sandy clayey silt is dominantly quartz and chert; biotite, muscovite, hornblende, calcite, zircon, sphene, rutile, magnetite, monazite, chlorite, hypersthene, tourmaline, garnet, pyroxene, apatite, orthoclase, plagioclase, and other minerals are present. Grains are well rounded to angular and many are of several generations. The calcite is crystalline and well rounded to angular. The feldspars are cloudy with alteration products. The other samples reveal similar mineral suites.

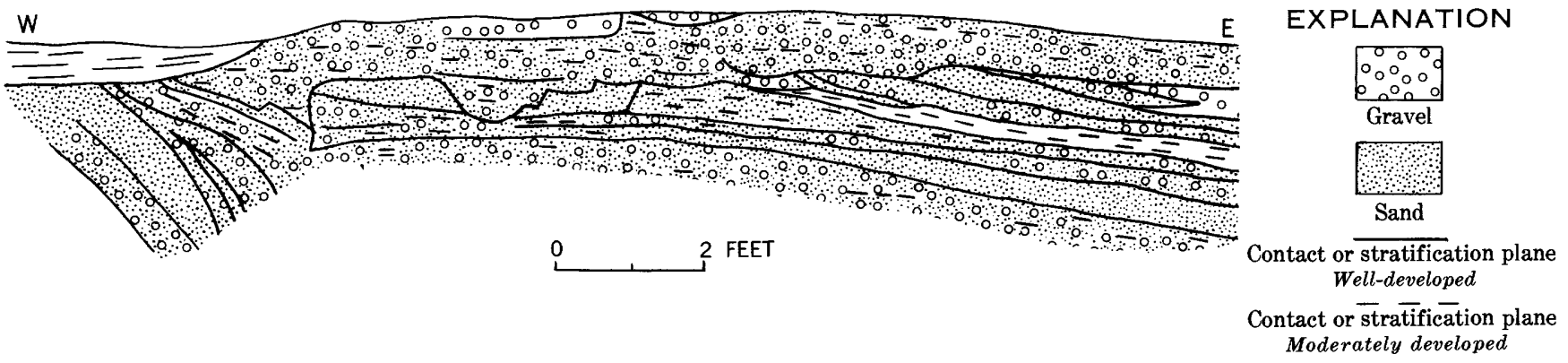

FIGURE 30.-Diagrammatic cross section through an uplifted bar, 1 mile east of the naval airbase near Barrow.

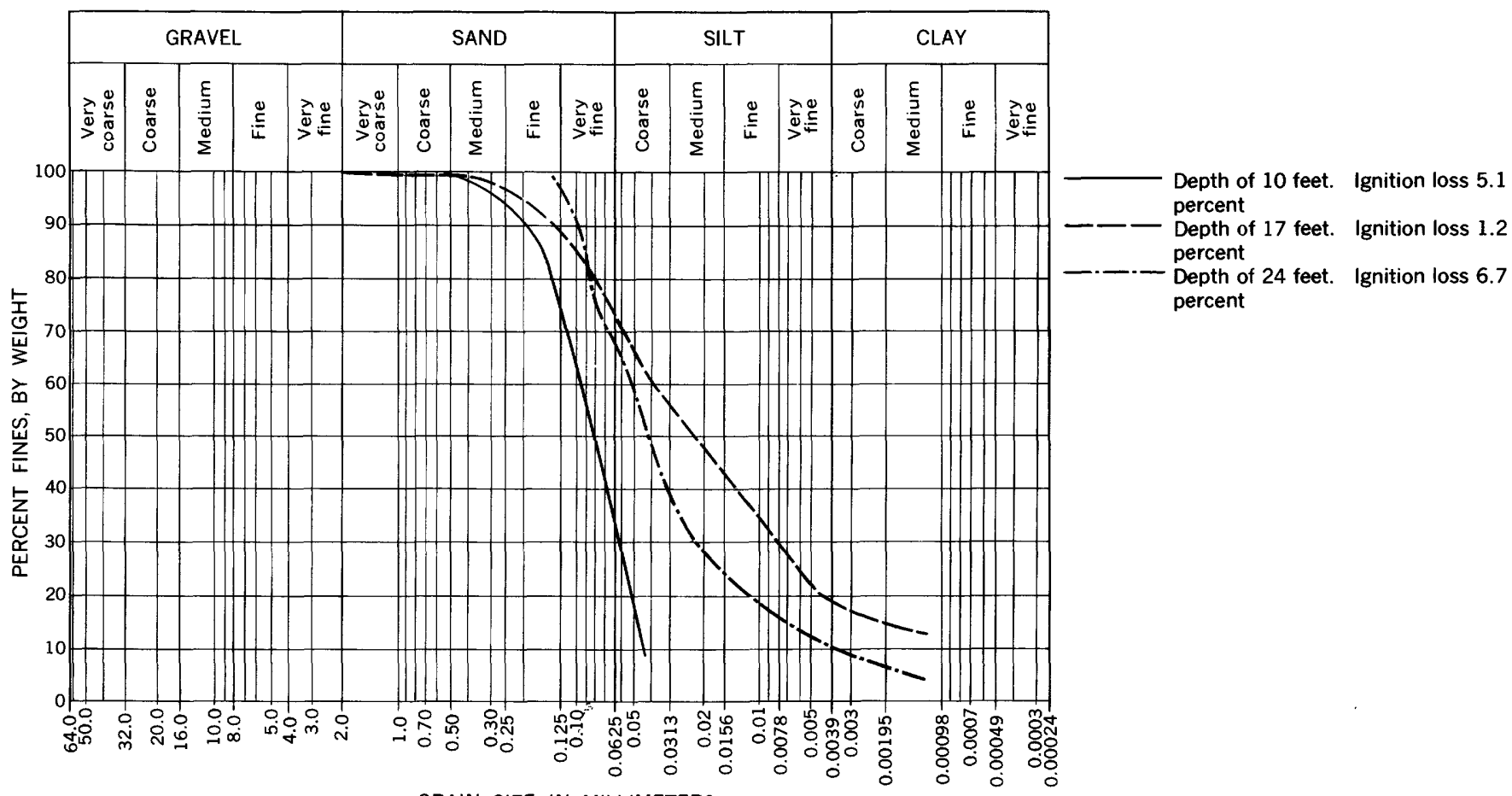

GRAIN SIZE, IN MILLIMETERS 
PEARD BAY

On August 3 to 5, 1947, six samples were obtained from the bluffs along the south side of Peard Bay, about 70 miles southwest of Barrow. The section was obscured by slump in most places, but locally it was exposed over a vertical range of 12 feet. There the Gubik formation consists of silt, clay, sand, and mixtures of these sediments in complexly intercalated lenses a fraction of an inch to several inches thick, and a few inches to several hundred feet in areal extent. The lenses range from light gray through yellow, tan, and brown to black; yellow-brown predominates. The sediments bear a strong superficial resemblance to the Gubik in the ice cellar at Barrow; they are referred to the Barrow unit.

The dominant mineral is quartz of several generations; typically it ranges from clear, colorless angular fragments or euhedral crystals to frosted or pitted stained rounded grains. Chert is the next most abundant mineral in silt and sand and in pebbles. The chert is generally rounded, smooth, and polished; but pitted, cracked, or broken fragments are common, as in the Barrow unit at Barrow. The chert is white, cream, tan, brown, green, gray, and black. These two minerals make up more than 95 percent of the material. Coal is a common constituent; other minerals and rocks are present, but microscopic studies were not completed prior to loss of the samples. Marine shell fragments are scattered in most of the sections. The mechanical analyses shown on figure 32 are probably typical. The exposed materials are interpreted as shallow-water marine or lagoonal deposits.

CAPE SIMPSON

In 1948 at Cape Simpson, Patton (1948), investigated three oil seeps with 10 shallow tests pits and provided the following information on the Gubik Formation:

Below the frost line three types of material were encountered : blue-gray clay, yellow-brown silt commonly containing rounded chert and quartzite pebbles, and ice. The clay and silt appeared to be interbedded. Above the frost, which occurred at a depth of two feet, was a cover of pitch, pitch-bound silt and moss.

Some limey shale, limestone and ironstone float on several of the mounds has prompted several geologists [Paige, Foran, and Gilluly 1925, p. 23] to suggest that these peculiar topographic features are directly underlain by hardrock. However, no consolidated bedrock in place was encountered in any of the test pits. An occasional isolated fragment of shale or limestone was unearthed. It seems probable that these as well as the surface float were brought up from some depth by frost action.

At the northern end of the mound from which seep No. 1 [3 miles northwest of the Cape] emerges, a 20-foot section through the mound is exposed in a beach bluff, The mound-forming material here is a blue-gray clay and massive blocks and wedges of ice. No consolidated bedrock was found.

Eight samples of clay and silt from the test pits were submitted to $\mathrm{H}$. N. Loeblich for microfossil determinations. Of the

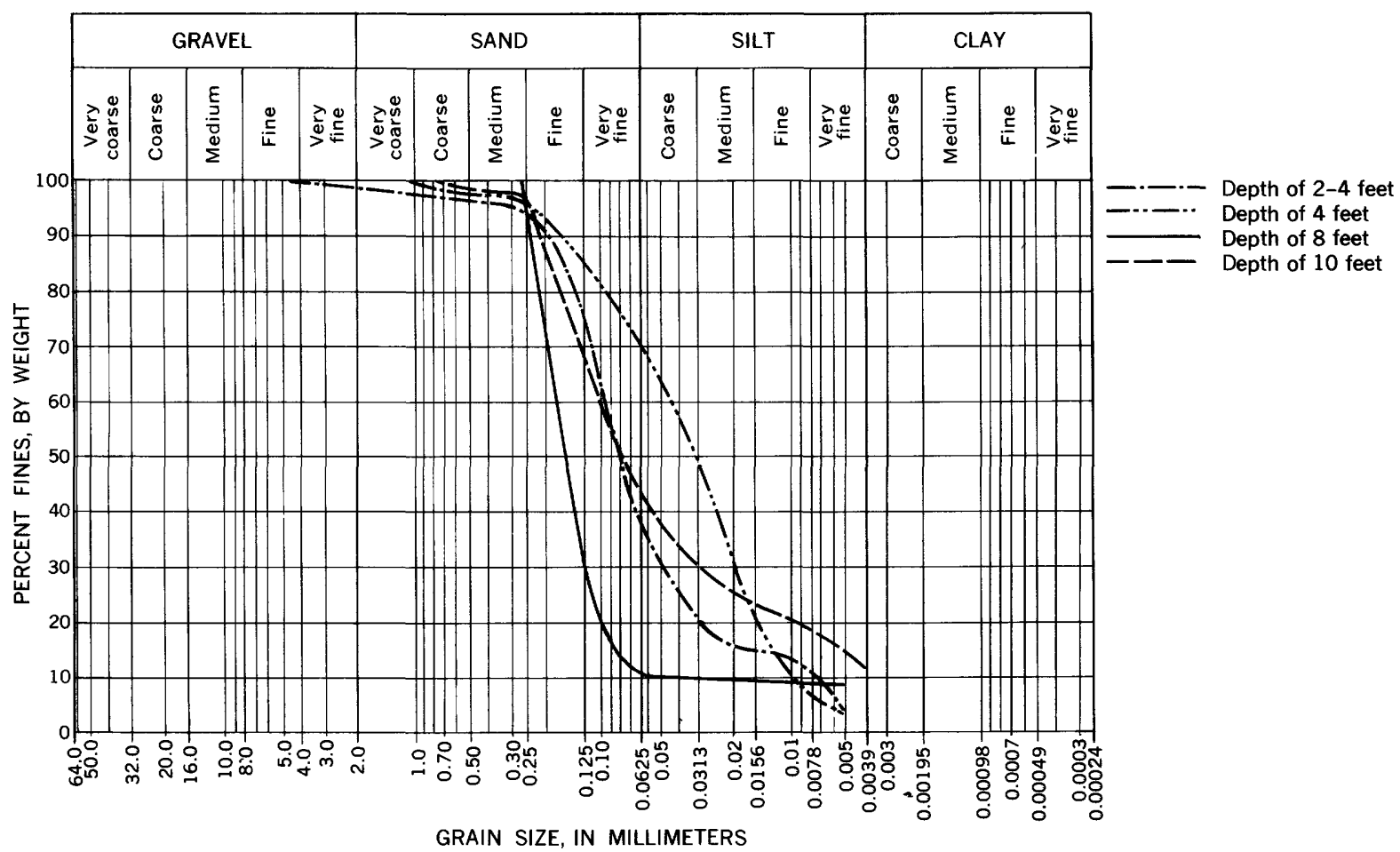

Figdre 32.- Size-grade cumulative curves of the Barrow unit of the Gubik Formation from Peard Bay. 
eight, six were found barren. The other two contained the following species :

48APa 29 Brown silt, pit No. 6, seep No. 2 [2 miles southwest of the Cape]-Elphidium spp., Cornuspira sp., Eponides sp. Anomalina sp., and Nonion sp.

48APa 31 Clay, pit No. 3, seep No. 1 [3 miles northwest of the Cape]-Elphidium A. Elphidium F, Cornuspira A, Anomalina $\mathrm{D}$, and Quinqueloculina B.

Mrs. Leoblich states that these forms are late TertiaryQuaternary undifferentiated.

Below the surficial cover of pitch, fresh green oil was found to be oozing up through steeply dipping fissures in the frozen ground. These fissures vary in width from several inches to a foot and are filled with loosely compacted, oil-saturated silt or clay. Both downdip and along the strike the fissures are highly irregular and do not appear oriented in any particular direction. There is evidence that a small amount of movement may have taken place along some of these fractures $* * *$. From the test-pit operations it is concluded that the mounds on which the oil seeps are located as well as the other mounds in the vicinity are not erosional remnants of consolidated bedrock. It is probable that they result from local frost action. Fissuring of the frozen ground accompanying the upheavals provided channels through which oil could escape from a reservoir below.

Nothing about the nature of the reservoir or the depth to bedrock could be determined from the test-pit studies.

\section{AGE AND CORRELATION OF THE GUBIK FORMATION}

MacNeil (1957, p. 108-109) tentatively correlated all fossil collections from unconsolidated surficial deposits west of the Colville River with the Gubik Formation but with the reservation that the formation might not all be of Pleistocene age. The fauna from the Colville River and possibly from Skull Cliff he regarded as late Pliocene or early Pleistocene. The fauna, according to MacNeil, seems to be most closely related to a fauna occurring in the Pribilof Islands. These findings are not appreciably different from those of the earlier workers, whose reports he referred to.

MacNeil (1957, p. 108) also interpreted the fauna from the Colville River as equivalent to or possibly older than the fauna from Skull Cliff ; both appear older than the fauna from the Meade River. 'Faunas from the Kukpowruk River and from Point Barrow are probably younger than the fauna from Meade River. The abundance of Macomas in the Gubik beds locally might distinguish the Pleistocene Gubik from Recent beach sands, according to MacNeil (written communication, Jan. 4, 1957).

The order of age of the faunas agrees with the writer's interpretation of the sequence of deposition, but on the basis of geomorphic evidence the deposition of the Gubik did not require all the Pleistocene and late Pliocene. Upper Cretaceous marine rocks everywhere underlie unconformably the unconsolidated Gubik Formation west of the Colville River. The lowermost
Gubik sediments west of the Colville River are clearly post-lower Pliocene on the basis of fossils (MacNeil, 1957 , p. 108-109) and therefore are younger than the Sagavanirktok Formation of early Tertiary age east of the Colville River. The Sagavanirktok Formation was deposited from the gradually rising Brooks Range to the south (Payne and others, 1951), and temperate climates are implied by coal beds derived from organic material deposited in basins (Chaney, 1940). In contrast, poor sorting, erratics, and general texture and appearance of local parts of the Skull Cliff unit suggest that it may represent a marine-deposited till. Land ice would not necessarily have to carry the debris directly to its present resting place; ice rafting would suffice.

Assuming the Skull Cliff unit was deposited during glacial times, the problem is to determine which major subdivision of the Pleistocene it represents. This has not been accomplished. Detterman, Bowsher, and Dutro (1958) correlated the glacial sequence in the Brooks Range and glacial outwash in the Gubik in part with pre-Wisconsin glaciation but did not cite specific sections. Evidence for age of most of the Gubik Formation is inconclusive or conflicting. The evidence consists of modification of geomorphic features, carbon-14 dates of organic matter incorporated in the Gubik, marine invertebrate and terrestrial vertebrate fossils, archeologic finds, and rate of growth of ice wedges.

As pointed out by Smith and Mertie (1930, p. 48), the original surface features are most modified farthest from the sea, and those nearest the coast are affected least. This fact suggests that the Barrow unit must be younger than the Meade River unit, but it does not indicate a specific age or definite means of correlation with the Pleistocene glaciations. However, the textural and lithologic maturity of the Meade River unit in contrast with the Barrow or Skull Cliff units suggests nonglacial times or at least the absence of easily obtained clastics of great diversity of sizes and composition. Much reworking of the Meade River sands certainly is necessary for their formation, but no specific time can be allocated to the process. A few thousand years are sufficient; many tens of thousands of years conceivably are possible. Hence, either an intraglacial stade or an interglaciation might be represented.

Coniferous and deciduous driftwood is carried by marine currents today along the Alaskan coast from sources elsewhere in Alaska, Canada, and Russia (Giddings, 1952), and similar wood can also be found at depth in the Gubik and inland onto the foothills. $\mathrm{H}$. W. Coulter (written communications, January 16 and 28,1958 ) collected part of a driftwood spruce log from a depth of 16 feet in the Barrow unit 5 miles southwest 
of Barrow, which has been carbon-14 dated as "more than 38,000 years." He mentioned that the log does not show much abrasion or weathering. Peat collected by K. M. Hussey at depths of 12 and 44 inches in sediments deposited in a lake 4 miles south-southwest of

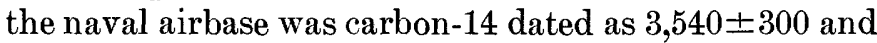
$9,100 \pm 260$ years B. P., respectively. (Samples submitted by H. W. Coulter to the U.S. Geological Survey; written communication, December 4, 1959.) These three dates might be interpreted as bracketing that portion of the Barrow unit from a depth of 1 to 16 feet. However, truncated ice wedges beneath the lake are almost identical in size to those surrounding the lake today. The present ice wedges surrounding the lake are growing actively, increasing width perhaps $1 \mathrm{~mm}$ a year on the average (Black, 1952b); those beneath the lake are not. Thus, it does not seem reasonable to assign an age of thousands of years to the lake sediments. If the lake sediments were thousands of years old, a marked difference in size of the wedges would be apparent. Alternatively, "old" organic matter from the tundra must have caved into the enlarging lake at a more recent date. In any case the tundra in the vicinity of the lake must be several thousand years old. In partial corroboration Tedrow and Douglas ${ }^{1}$ cited Carbon-14 dates of 10,600 to 10,900 years on organic matter from 2-foot depths in the soil on the emerged bar 1 mile inland from the airbase. If the oldest dates are approximately correct, the Barrow unit must represent much if not all of the Wisconsin Glaciation. One might then correlate the Meade River unit with the Sangamon Interglaciation and the Skull Cliff unit with the Illinoian Glaciation. What then happened during previous glaciations or interglaciations? Unfortunately, no evidence of early Pleistocene deposition has yet been found except for the correlation of the early Gubik invertebrate fossils with early Pleistocene or late Pliocene time. Archeological findings (Solecki, 1951) are only a few thousand years old. Pleistocene mammals, now extinct, lived as recently as 8,000 years ago (Sellards, 1952, p. 115 -116) and do not permit subdivision of the Pleistocene. The geomorphic evidence neither substantiates nor negates the paleontologic correlations. However, deposition during only part of the Pleistocene was needed for formation of the Gubik. It is obvious that further fieldwork is required to determine the age and correlation of the Gubik Formation.

\section{GEOMORPHIC HISTORY OF THE GUBIK FORMATION}

During the last part of Quaternary times, the Arctic coastal plain province of northern Alaska was the scene of shallow fluctuating seas, interrupted by brief emer-

\footnotetext{
1 Tedrow, J. C. F., and Douglas, L. A., 1958, Carbon-14 dating of some
} arctic solls : Rutgers Univ., mimeographed note, 6 p. gences of the land. Glaciation supplied some sediment to the Gubik Formation, at least indirectly. The history was exceedingly complicated in detail and cannot now be reconstructed except in gross outline. Smith and Mertie (1930, p. 48) pointed out:

the surface of this tract does not represent a single plain but instead is made up of a number of surfaces of erosion and deposition which have been formed during a long period of years and mark different stages of erosion and uplift. The characteristic feature of the whole province, however, is that practically everywhere its surface is formed of unconsolidated deposits that have been laid down mainly under marine conditions. These deposits have been uplifted and in part reworked and shaped by other agencies. Presumably at one time this province was similar to the present floor of the sea off this coast. Later it was uplifted and as soon as it rose above the sea was exposed to the same kinds of erosional and depositional processes that are even now tending to modify and shape its appearance. Many of its features therefore represent the inequalities that existed on its surface when it was part of the floor of the sea, others are the gullies formed by the run-off from the latest shower of rain, and between these two extremes are all gradations.

On the whole, however, in a geologic sense the province is young, and there has not yet been time for the present processes to remodel its features to fit existing conditions. Consequently, large tracts have not yet acquired thorough drainage, and ponds and lakes that fill old depressions are numerous on the poorly drained uplands. Because the inland part of the coastal plain has been longest above the sea, its original surface features are most modified, and the parts nearest the coast have been affected least.

In large measure, the foregoing statement is as appropriate today as it was several decades ago. Turf is found 4 and 10 feet beneath the sea in the Point Barrow spit, and emerged bars and beaches are found literally by the dozen at elevations of 2 to 600 feet from the back shore to the foothills. Tracing of the boundary between the foothills and the coastal plain reveals in many places a wave-cut cliff that is warped from a point near sea level on the west near Cape Beaufort to 600 feet elevation south of Barrow and down to a few tens of feet near Umiat. Uplift of the coastal plain obviously has not been uniform in either time or place, but details are lacking. Moreover, if the sediments of the Meade River unit are pre-Wisconsin in age, as seems possible, many tens of thousands of years have passed with little evidence remaining or recognized of the events that transpired since its deposition.

The major streams of the coastal plain apparently are largely consequent upon the origimal upwarped surface and fan outward from the crest of the arch. In places valleys many tens of feet deep have been carved through the Gubik and for some feet into the underlying Cretaceous rocks. Emerged bars, beaches, lagoons, and other coastal features however, are still fresh and readily recognized. Associated with the emerged coastal features and situated between them are thou- 
sands of oriented lakes and drained-lake basins. Many of the lakes are shallow and merely truncate the ubiquitous ice wedges. They are enlarging mostly by caving and are true thermokarst lakes. As the truncated wedges under the very shallow lakes are only slightly smaller than those under the tundra adjacent, these lakes cannot be more than a few hundred years old. Other deep lakes have thawed out deep basins in the permafrost and seemingly are many thousands of years old. The apparent similarity of maximum size of ice wedges over the whole coastal plain implies that they started to grow at about the same time. Only the more recent constructional features, such as the Point Barrow spit, emerged lagoon near Barrow, and the many swampy lakebeds have more youthful ice wedges. Dated archeological sites (Collins, 1933 and 1951; Stefansson, 1914, p. 393-394; and Wissler, 1916, p. 440) at Barrow are cut by ice wedges and tend to confirm the validity of the dates of the ice wedges, which on the Point Barrow spit are 800 to 1,000 years old. On the tundra, average wedges, 1 to 3 meters wide, are on the order of 1,000 to 3,000 years old. Most wedges need less than 5,000 years to form, although some may well be twice that old. Buried wedges, those whose tops were truncated by deep thaw, are common. Conditions favorable for producing ice wedges obviously cannot be traced back much beyond 10,000 years without a break, yet cold climates and permafrost which extends to depths of more than 300 meters have been present much longer. Structures interpreted as fossil ice wedges, ice-shoved ridges, and fillings around ice blocks attest to cold climates and permafrost during deposition of at least 20 feet of the upper part of the Barrow unit, a time apparently encompassing several tens of thousands of years.

Rapid retreat of the coast (MacCarthy, 1953) by wave action during the summer is obvious. Wind action today (Black, 1951) moves sand effectively and distributes loess over much of the coastal plain. Typical dune crossbedding and wind-sorted and frosted sand grains are widespread in the Meade River unit. Mass movement of material on slopes is very rapid. The solifluction mantle near Umiat studied by Livingstone $(1955,1957)$ seemingly spans about the same time as the currently active ice wedges. These and other geomorphic processes are rapidly modifying the Gubik sediments where they are exposed. However, the subaerial processes now affecting the Gubik Formation seemingly did not all act with their present intensity, if indeed they acted at all, during the brief emergences of the coastal plain. Much more information must be obtained before the statements of Smith and Mertie (1930) can be modified significantly.

\section{ENGINEERING SIGNIFICANCE OF THE GUBIR FORMATION}

The Gubik Formation, consisting of unconsolidated fine-grained materials, does not in itself produce prob. lems in engineering any more unusual than do similar materials in conterminous United States. However, the fact that the formation is perennially frozen and generally contains more ice than pore space is of great engineering significance. Permafrost, by prohibiting ground-water infiltration and migration, precludes the drilling of shallow wells for water or the installation of septic tanks for sewage disposal. Excavations into frozen ground cannot be made with the same ease or even with the same equipment as in unfrozen materials Moreover, construction in or on permafrost must always be designed in such a way as to prohibit tha wing of the underlying ice and subsequent failure of the structure. Many of the engineering problems regarding perma. frost have been met and solved; others are still to be met. Some problems in engineering geology caused by permafrost in the Arctic coastal plain have been reviewed by Black (1957), Reed (1958), and other pertinent references cited. The major problems pertain to overland transportation, construction, water supplr and sewage disposal, and drilling for and production of oil and gas.

\section{REFERENCES CITED}

Black, R. F., 1951, Eolian deposits of Alaska : Arctic, v. 4, no. 2 p. 89-111.

1952a, Polygonal patterns and ground conditions from aerial photographs. Photogramm. Eng., v. 18, no. 1. p. 123-134.

-1952b, Growth of ice-wedge polygons in permafrost neat Barrow, Alaska [abs.]: Geol. Soc. America Bull., v. 63. p. 1235-1236.

1954, Permafrost-a review : Geol. Soc. America Bull., r. 65 , p. 839-856.

1957, Some problems in engineering geology caused br permafrost in the Arctic coastal plain, northern Alaska: Arctic, v. 10, p. 230-240.

Black, R. F. and Barksdale, W. L., 1949, Oriented lakes of northern Alaska: Jour. Geology, v. 57, no. 2, p. 105-118.

Brooks, A. H., 1906, The geography and geology of Alaska: U.S Geol. Survey Prof. Paper 45, 327 p.

Chaney, R. W., 1940, Tertiary forests and continental history: Geol. Soc. America Bull., v. 51, p. 469-488.

Collins, H. B., Jr., 1933, Archaeological investigations at Point Barrow, Alaska: Smithsonian Inst. Explor. and Fieldwork in 1932 , p. $45-48$.

-1951, The origin and antiquity of the Eskimo: Smith sonian Inst. Ann. Rept. for 1950, p. 423-468.

Dall, W. H., and Harris, G. D., 1892, Correlation papersNeocene: U.S. Geol. Survey Bull. 84, 349 p.

Detterman, R. L., Bowsher, A. L., and Dutro, J. T., Jr., 1958. Glaciation on the Arctic slope of the Brooks Range, north ern Alaska : Arctic, v. 11, p. 43-61.

Giddings, J. L., Jr., 1952, Driftwood and problems of Arctic Sea currents: Am. Philos. Soc. Proc., v. 96, no. 2, p. 129-142. 
Leffingwell, E. de K., 1919, The Caming River region, northern Alaska: U.S. Geol. Survey Prof. Paper 109, $251 \mathrm{p}$.

Livingstone, D. A., 1955, Some pollen profiles from Arctic Alaska: Ecology, v. 36, no. 4, p. 587-600.

-1957 , Pollen analysis of a valley fill near Umiat, Alaska : Am. Jour. Sci., v. 25., p. 254-260.

NacCarthy, G. R., 1953, Recent changes in the shoreline near Point Barrow, Alaska: Arctic, v. 6, no. 1, p. 44-51.

1958, Glacial boulders on the Arctic coast of Alaska: Arctic, v. 11, p. 71-85.

NacKay, J. R., 1959, Glacier ice-thrust features of the Yukon Coast: Geog. Bull. no. 13. p. 5-21 ; abs. in Can. Geographer, no. 14, p. 42.

MacNeil, F. S., 1957, Cenozoic megafossils of northern Alaska : U.S. Geol. Survey Prof. Paper 294-C, p. 99-126.

Neek, C. E., 1923, Notes on the stratigraphy and Pleistocene fauna from Peard Bay, Arctic Alaska: California Univ., Dept. Geol. Sci. Bull., v. 14, p. 409-422.

Morris, R. H., 1952, Heavy-mineral analysis of sedimentary rocks of northern Alaska: U.S. Geol. Survey open-file report, $68 \mathrm{p}$.

Vational Research Council, 1947, Report of the subcommittee on sediment terminology : Am. Geophys. Union Trans., v. 28 , no. 6 , p. $936-938$.

Paige, Sidney, Foran, W. T., and Gilluly, James, 1925, A reconnaissance of the Point Barrow region, Alaska: U.S. Geol. Survey Bull. 772, 33 p.

Patton, W. W., Jr., 1948, Geological results of test pit operations at Cape Simpson, Alaska: U.S. Geol. Survey Geol. Inv., Naval Petroleum Reserve No. 4, [Regular] Rept. 22, 6 p.

Payne, T. G., 1953, Mesozoic and Cenozoic tectonic elements of Alaska: U.S. Geol. Survey Misc. Geol. Inv. Map I-84, 2 sheets.

Payne, T. G., and others, 1951, Geology of the Arctic Slope of Alaska: U.S. Geol. Survey Oil and Gas Inv. Map OM-126, 3 sheets.
Reed, J. C., 1958, Exploration of Naval Petroleum Reserve No. 4 and adjacent areas, northern Alaska, 1944-53. Part 1 . History of the Exploration: U.S. Geol Survey Prof. Paper $301,192 \mathrm{p}$.

Sanford, R. S., and Pierce, H. C., 1946, Exploration of coal deposits of the Point Barrow and Wainwright areas, northern Alaska : U.S. Bur. Mines Rept. Inv. 3934, 17 p.

Schrader, F. C., 1904, A reconnaissance of northern Alaska: U.S. Geol. Survey Prof. Paper 20, 139 p.

Sellards, E. H., 1952, Early man in America-a study in prehistory : Texas Univ. Press, 211 p.

Smith, P. S., and Mertie, J. B., Jr., 1930, Geology and mineral resources of northwestern Alaska: U.S. Geol. Survey Bull. $815,351 \mathrm{p}$.

Solecki, R. S., 1951, Archeology and ecology on the Arctic Slope of Alaska: Smithsonian Inst. Ann. Rept. for 1950, p. 469-496.

Stefansson, Vilhjalmur, 1914, The Stefansson-Anderson Arctic expedition of the American Museum-preliminary ethnological report: Am. Mus. Nat. History Anthropol. Papers, v. 14, pt. 1, $395 \mathrm{p}$.

Stefansson, Karl, Thurrell, R. F., Jr., and Zumberge, J. H., 1948, Stratigraphy and structure of the area of the Colville River north of Umiat, Alaska: U.S. Geol. Survey Geol. Inv., Naval Petroleum Reserve No. 4, [Regular] Rept. 12, $29 \mathrm{p}$.

Tappan, Helen, 1951, Northern Alaska index foraminifera: Cushman Foundation Foram. Research Contr., v. 2, pt. 1, p. 1-8.

Webber, E. J., 1947, Stratigraphy and structure of the area of the Meade and Kuk Rivers and Point Barrow, Alaska: U.S. Geol. Survey Geol. Inv., Naval Petroleum Reserve No. 4, [Regular] Rept. 6, 14 p. 